\title{
Alternatives for Chemical and Biochemical Lignin Valorization: Hot Topics from a Bibliometric Analysis of the Research Published During the 2000-2016 Period
}

\author{
Ricardo Abejón ${ }^{1, *(D)}$, Heriberto Pérez-Acebo ${ }^{2}$ (D) and Leonardo Clavijo 3 (D) \\ 1 Chemical and Biomolecular Engineering Department, University of Cantabria. Av. Los Castros s/n, \\ 39005 Santander, Spain \\ 2 Mechanical Engineering Department, University of the Basque Country UPV/EHU, P Rafael Moreno \\ "Pitxitxi" 2, 48013 Bilbao, Spain; heriberto.perez@ehu.eus \\ 3 Forest Process Engineering Group, Chemical Engineering Institute, Faculty of Engineering, Universidad de \\ la República, Av. J. Herrera y Reissig 565, Montevideo 11300, Uruguay; lclavijo@fing.edu.uy \\ * Correspondence: abejonr@unican.es or ricardo.abejon@hotmail.com; Tel.: +34-942201579; Fax: +34-942201591
}

Received: 6 July 2018; Accepted: 21 July 2018; Published: 24 July 2018

\begin{abstract}
A complete bibliometric analysis of the Scopus database was performed to identify the research trends related to lignin valorization from 2000 to 2016 . The results from this analysis revealed an exponentially increasing number of publications and a high relevance of interdisciplinary collaboration. The simultaneous valorization of the three main components of lignocellulosic biomass (cellulose, hemicellulose, and lignin) has been revealed as a key aspect and optimal pretreatment is required for the subsequent lignin valorization. Research covers the determination of the lignin structure, isolation, and characterization; depolymerization by thermal and thermochemical methods; chemical, biochemical and biological conversion of depolymerized lignin; and lignin applications. Most methods for lignin depolymerization are focused on the selective cleavage of the $\beta-\mathrm{O}-4$ linkage. Although many depolymerization methods have been developed, depolymerization with sodium hydroxide is the dominant process at industrial scale. Oxidative conversion of lignin is the most used method for the chemical lignin upgrading. Lignin uses can be classified according to its structure into lignin-derived aromatic compounds, lignin-derived carbon materials and lignin-derived polymeric materials. There are many advances in all approaches, but lignin-derived polymeric materials appear as a promising option.
\end{abstract}

Keywords: lignin valorization; lignin uses; lignocellulosic biomass; bibliometric analysis; research trends

\section{Introduction}

A sustainable future requires the replacement of fossil resources for energy supply and production of chemicals. Biomass is the only natural carbon-containing resource that is available in enough quantity to replace fossil resources [1]. Bioenergy, biofuels, and bio-based chemicals are the main pillars that must support this transition from a fossil-based to a sustainable biomass-based economy. However, the expected growth of the global population and the promotion of living quality in developing countries will combine increased food and energy demands subject to restricted land availability and water supply [2]. Under these conditions, lignocellulosic biomass appears as a promising renewable raw material, since it can be obtained from marginal and degraded land and does not contribute to food supply. Moreover, a significant amount of waste lignocellulosic biomass is available from the agro-industrial, pulping and paper and other sectors related to forestry. 
Lignocellulosic biomass consists in three main components: cellulose, hemicellulose, and lignin. Cellulose, the major component of lignocellulosic biomass, is the main structural component of plant cell walls. It is composed of linear chains of glucose units linked by $\beta$-glycosidic bonds. The intra-chain and inter-molecular hydrogen bonds shape microfibrils with amorphous and crystalline regions [3]. These crystalline regions exhibit resistance to enzymatic attack and insolubility in water and most organic solvents. Hemicellulose is the second main component of lignocellulosic biomass. It is a heteropolymer composed of hexoses and pentoses as main monomers. In this case, its heterogeneous and amorphous structure can be broken down more easily by thermal, chemical, or enzymatic processes. Finally, lignin is a highly complex aromatic heteropolymer that forms a random three-dimensional network comprised of three main types of monolignols: coniferyl alcohol, sinapyl alcohol and p-coumaryl alcohol. Lignin is more resilient than hemicellulose and cellulose to chemical and enzymatic degradation.

A biorefinery can be defined as a facility with integrated, efficient, and flexible conversion of biomass feedstocks, through a combination of physical, chemical, biochemical and/or thermochemical processes, into multiple products [4]. A sustainable biorefinery configuration must produce bio-based chemicals, bioenergy and biofuels making the most of the three main components of lignocellulosic biomass. The deconstruction of cellulose into glucose (fermentable sugar) to produce bio-ethanol has been extensively studied since the first generation production from edible feedstock was developed [5]. New advances have identified how hemicellulose can provide many potential applications for the generation of chemicals and biofuels: various techniques can be employed for the extraction and purification of hemicellulose from lignocellulosic biomass for further transformation [6,7].

The complex structure of lignin is highly variable, as it depends strongly on the type of biomass and on the part of the plant where it is synthetized, giving as a result different hyper branched structures with polydisperse molar masses [8]. These difficulties have caused the consideration of lignin-rich streams as residual streams to be combusted to produce heat and power. Only less than $5 \%$ of lignin is used in low-value commercial applications, such as concrete additive (lignosulphonates), active component in wood adhesives, binding and dispersing agent, emulsion stabilizer or retardant [9]. However, as lignin accounts for $10-35 \%$ by weight in lignocellulosic biomass, the effective utilization of lignin must play a major role in the biorefinery conception. The chemical structure of lignin makes it the most suitable renewable feedstock to produce aromatic platform chemicals. Great research efforts have been focused on the production of high value-added chemicals from lignin during the last years. Pretreatment processes drive the fractionation of the lignocellulosic biomass into the main components. Once lignin is separated, its depolymerization to aromatic compounds (as an alternative to the petrochemical industry) is probably the most promising way to achieve the sustainable utilization of lignin [10]. After depolymerizing the lignin into monomeric subunits, the upgrading of these monomers to valuable compounds is required [11]. There is a huge number of research publications that have investigated lignin processing and valorization, including the recovery of lignin from biomass, its depolymerization and further upgrading. To handle all the information that results from a bibliographic search in this topic, the basic managing tools that bibliometrics provides are highly useful.

Bibliometrics is the application of quantitative analysis and statistical methods for the measurement of all aspects related to the publication and reading of documents. A bibliometric analysis provides effective tools to assess research trends on a scientific topic. This method has been broadly applied to analyze the scientific production and trends in numerous engineering fields [12-19]. The main objective of this work was to carry out a bibliometric analysis of the research publications regarding lignin valorization during the period from 2000 to 2016. The nature of the progression of research in this theme was investigated and the underlying patterns according to several criteria (publication year, document type, language, subject, journal, country, institution, and keywords) were identified. Finally, the most important hot topics were determined and the most promising innovative alternatives to be implemented in the future to valorize lignin were revised. 


\section{Data Source and Methodology}

Scopus was the bibliographic database selected for this bibliometric study. This database contains abstracts and citations for academic journal articles and it covers over 21,500 titles (more than 20,000 are peer reviewed journals) from over 5000 international publishers. Scopus states that it is the "largest abstract and citation database of peer-reviewed literature", with more than 38 million abstracts with references back to 1996 and more than 22 million records before that year, as far as 1823 [20]. Based on these figures, Scopus offers about $20 \%$ more coverage than Web of Science [21].

The online search in the Scopus database was performed in October 2017, employing "lignin" and "valorization" as keywords in the Article Title, Abstract, and Keywords field of the search-engine. This way, the complete bibliography published from 2000 to 2016 was retrieved. Additional tests were carried out to analyze the influence of alternative spelling variants ("valorisation" instead of "valorization") and singular or plural forms ("lignins" instead of "lignin"), but the results demonstrated that the number of documents was not affected by these circumstances. The total number of papers found was 359. However, 6 documents were listed twice. Consequently, 353 unique documents were found in the period 2000-2016. The bibliometric analysis considered the following aspects of the retrieved documents: publication year, document type, language, subject categories, journals, countries, and institutions.

\section{Results and Discussion}

\subsection{Bibliometric Analysis of Research on the Valorization of Lignin (2000-2016)}

\subsubsection{Publication Year, Document Type, and Language of Documents}

The distribution of annual publications shows that publications regarding lignin valorization increased over the years, as shown in Figure 1. Before 2008, only 6 papers were published, but after that year the number of documents increased rapidly, from 7 in 2008 to 108 papers in 2016. This fast growth implied that the cumulated number of publications (Figure 1b) followed an exponential trend (with a $\mathrm{R}^{2}$ value of 0.992 ). When compared to research on hemicellulose valorization, which followed a linear growth rate [22], this exponential trend suggests that the investigation on lignin valorization has gained more specific interest in the last years and is becoming a very hot research topic in the field of lignocellulosic biomass bio-refineries.

The document types were analyzed and 6 document types were found. The most frequent document type was Article, accounting for $74.8 \%$ of total publications, followed by Review (12.5\%), and Proceedings paper $(7.8 \%)$. The other document types (Book chapter, Book, and Short survey) jointly contributed less than $5 \%$. The percentages obtained were similar to the results reported by other bibliometric studies in the chemical engineering field, which have confirmed that Article is clearly the most common document type. However, the relative contributions of Proceeding papers and Reviews depend on the specific investigated topic. While a higher weight of Proceeding papers is usual for most engineering topics [23-25], some examples where Reviews are more relevant can be mentioned [26], including other bibliometric studies about biomass valorization [22].

The main part of the publications was published in English ( $97.7 \%$ of the documents). Only three other languages were found; French was the second language with five documents (although two of them were available in English too). The other two languages were anecdotal: three papers in Chinese and two in Spanish. Once again, English appears as the main language employed for scientific research since some decades ago [27]: most bibliometric studies reported that above $95 \%$ of scientific publications were written in English [28,29]. 
a)

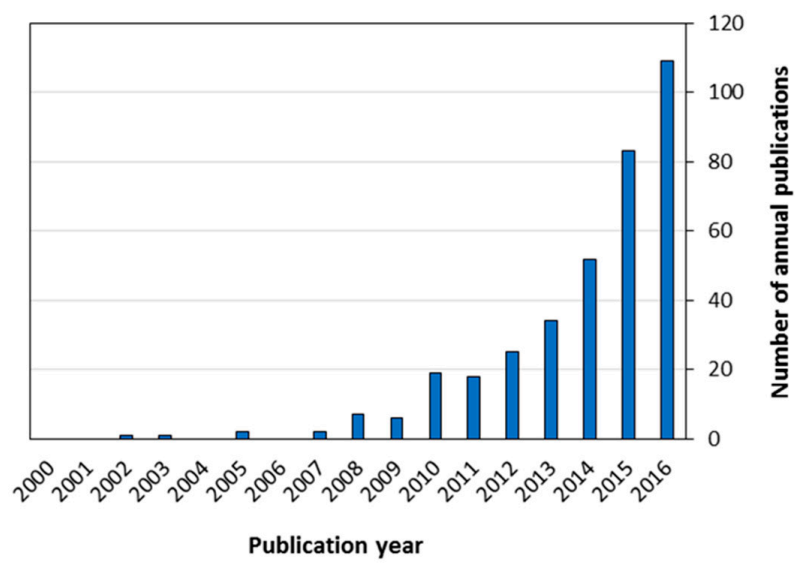

b)

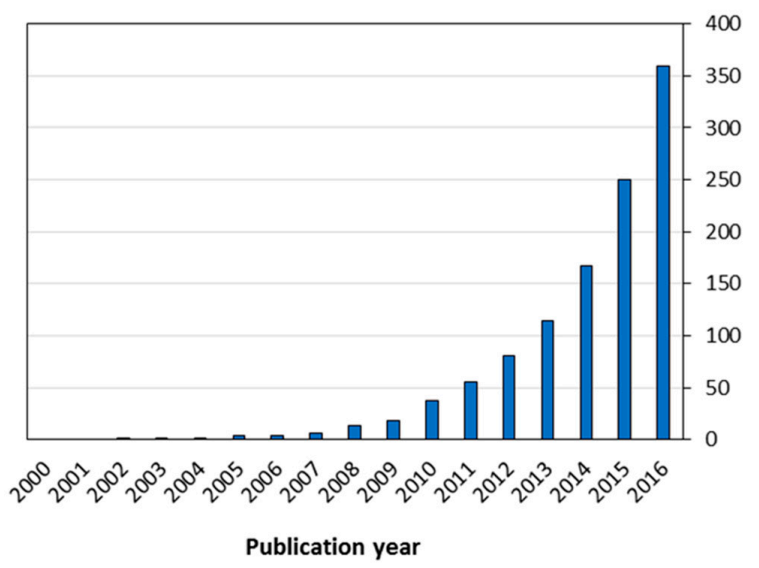

Figure 1. Annual (a) and cumulated (b) publication output.

\subsubsection{Distribution of Output in Subject Categories and Journals}

The classification of subject categories can be observed in Table 1, where the 8 most common categories are shown. Because of interdisciplinary research, the categories are non-exclusive and a publication can be classified into more than one category. Therefore, the sum of the number of documents in these categories is above the total number of documents, and a similar result can be found when percentages are analyzed, with results above 100\%. Chemical Engineering was the leading category with 150 documents (41.8\% of the total), followed by Environmental Science, and Chemistry categories, which ranked the second and third positions with $129(35.9 \%)$ and 117 (32.6\%) papers, respectively. These results, with three different subjects with contributions higher than $30 \%$, indicated a clear evidence of multidisciplinary collaboration focused on lignin valorization, as previously reported for hemicellulose valorization [22].

Table 1. The top 8 most common subject categories.

\begin{tabular}{cccc}
\hline Ranking & Subject & Documents & Percentage (\%) \\
\hline 1 & Chemical Engineering & 153 & 42.6 \\
2 & Environmental Science & 133 & 37.0 \\
3 & Chemistry & 118 & 32.9 \\
4 & Energy & 101 & 28.1 \\
5 & Agricultural and Biological Sciences & 55 & 15.3 \\
6 & Biochemistry, Genetics and Molecular Biology & 55 & 15.3 \\
7 & Materials Science & 45 & 12.5 \\
8 & Engineering & 37 & 10.3 \\
\hline
\end{tabular}


The investigation results about the 5 most frequently published journals are listed in Table 2 . It shows that ACS Sustainable Chemistry and Engineering ranked in the first position with 22 documents (6.1\%), while Industrial Crops and Products occupied the second position (21 publications, 5.8\%) and Bioresource Technology the third (20 publications, 5.6\%). The leader journal is focused on the topics related to the subjects Chemical Engineering and Chemistry, with special attention to green chemistry and engineering, but the other journals introduce new subjects and disciplines. On the one hand, Industrial Crops and Products is a journal centered in the subject Agricultural and Biological Sciences, which covers research on industrial crops and products. On the other hand, Bioresource Technology is a journal linked to the Chemical Engineering and Environmental Sciences subjects, more specifically focused on the areas related to biomass and bioprocesses. As occurred with the case of subject categories, the analysis of journals revealed again the importance of the multidisciplinary research on lignin valorization.

Table 2. The top 5 most productive journals (IF and SJR values correspond to 2016).

\begin{tabular}{cccccc}
\hline Ranking & Source & IF (WoS) & SJR (Scopus) & Documents & Percentage (\%) \\
\hline 1 & ACS Sustainable Chemistry and Engineering & 5.951 & 1.523 & 22 & 6.1 \\
2 & Industrial Crops and Products & 3.181 & 1.059 & 21 & 5.8 \\
3 & Bioresource Technology & 5.651 & 2.191 & 20 & 5.6 \\
4 & Green Chemistry & 9.125 & 2.564 & 16 & 4.5 \\
5 & ChemSusChem & 7.226 & 2.385 & 15 & 4.2 \\
\hline
\end{tabular}

\subsubsection{Publication Distribution of Countries and Institutions}

The analysis of the geographical distribution of the authors was based on documents with available address and affiliation of at least one author. There were 2 papers without country and affiliation identification, so the total number of documents considered for the analysis of country contribution was 351. Among all the documents with author information, 255 (72.6\%) were single country publications and $96(27.4 \%)$ were international collaborative publications. The contribution of the 11 most productive countries (at least 15 papers) in lignin valorization research from 2000 to 2016 is shown in Table 3 as well as other information: the ranking and percentage of contributions according to single country, internationally collaborated documents, first authors and corresponding authors. In categories like total publications or international collaboration rank, since the country affiliation is not exclusive (a document can be contributed by authors from more than one country), some papers may be indexed in more than one country simultaneously. Consequently, the sum of the number of documents in these categories is above the total number. In the top 11 countries, there are two countries from North America (USA and Canada), seven countries from Europe, China from Asia, and Brazil from South America. The USA was the most productive country with the largest number of documents (66), which suppose $18.8 \%$ of the total publications, followed by four European countries (Spain, France, Netherlands, and Portugal from second to fifth position, respectively). The joint contribution of these four countries was $43.9 \%$ and the figure increased to $59.5 \%$ when the contributions of the other three European countries in Table 3, Belgium (7th position), Germany (8th), and Italy (11th), were added. The sixth position corresponded to China, with 22 documents ( $6.3 \%$ contribution).

The contribution of the 10 most productive institutions in research on lignin valorization is shown in Table 4. Only Spain and Portugal contributed more than an institution to this top ranking. On the one hand, a Spanish university (Universidad del País Vasco/Euskal Herriko Unibertsitatea UPV/EHU) was the most productive institution, with 19 documents (5.4\%) and another university from Spain (Universidad de Córdoba) appeared in the third position (11 documents and 3.1\% contribution). Moreover, two Portuguese universities (Technical University of Lisbon with 9 documents and University of Lisbon with 8 documents) appeared in the ranking, but the institutions merged in 2013. The second position corresponded to the National Renewable Energy Laboratory (14 documents), the first institution from the USA, which have proposed relevant alternatives to valorize lignocellulosic biomass for both energetic and chemical purposes [30,31]. The most productive institutions are the ones belonging to countries listed in Table 3 . 
Table 3. The top 10 most productive countries.

\begin{tabular}{ccccccccccc}
\hline Country & TP & $\mathbf{( \% )}$ & SPR & $\mathbf{( \% )}$ & ICPR & $\mathbf{( \% )}$ & FAPR & $\mathbf{( \% )}$ & CAPR & $(\mathbf{\% )}$ \\
\hline USA & 66 & $(18.8)$ & 1 & $(17.5)$ & 2 & $(22.9)$ & 1 & $(14.5)$ & 1 & $(15.1)$ \\
Spain & 53 & $(15.1)$ & 3 & $(11.4)$ & 1 & $(25.0)$ & 3 & $(9.7)$ & 3 & $(11.1)$ \\
France & 48 & $(13.7)$ & 2 & $(11.8)$ & 3 & $(18.8)$ & 2 & $(10.3)$ & 2 & $(11.4)$ \\
Netherlands & 29 & $(8.3)$ & 4 & $(7.1)$ & 6 & $(11.5)$ & 4 & $(6.3)$ & 4 & $(7.1)$ \\
Portugal & 24 & $(6.8)$ & 6 & $(5.5)$ & 7 & $(10.4)$ & 6 & $(5.1)$ & 5 & $(6.3)$ \\
China & 22 & $(6.3)$ & 5 & $(5.9)$ & 9 & $(7.3)$ & 5 & $(6.0)$ & 6 & $(5.7)$ \\
Belgium & 20 & $(5.7)$ & 9 & $(3.1)$ & 5 & $(12.5)$ & 7 & $(4.8)$ & 7 & $(4.6)$ \\
Germany & 20 & $(5.7)$ & 10 & $(2.7)$ & 4 & $(13.5)$ & 10 & $(3.7)$ & 8 & $(3.7)$ \\
Brazil & 16 & $(4.6)$ & 12 & $(2.4)$ & 7 & $(10.4)$ & 8 & $(4.3)$ & 12 & $(2.6)$ \\
Canada & 15 & $(4.3)$ & 7 & $(3.9)$ & 14 & $(5.2)$ & 12 & $(3.1)$ & 10 & $(3.4)$ \\
Italy & 15 & $(4.3)$ & 8 & $(3.5)$ & 11 & $(6.3)$ & 9 & $(4.0)$ & 8 & $(3.7)$ \\
\hline
\end{tabular}

TP: Total publications; SPR: Single country publication rank; ICPR: International collaboration publication rank; FAPR: First author publication rank; CAPR: Corresponding author publication rank.

Table 4. The top 10 most productive institutions.

\begin{tabular}{cccc}
\hline Ranking & Institution & Documents & Percentage (\%) \\
\hline 1 & Universidad del País Vasco & 19 & 5.3 \\
2 & National Renewable Energy Laboratory & 14 & 3.9 \\
3 & Universidad de Córdoba & 11 & 3.1 \\
4 & Centre National de la Recherche Scientifique & 10 & 2.8 \\
5 & Rheinisch-Westfalische Technische Hochschule Aachen & 10 & 2.8 \\
6 & Energy Research Centre of the Netherlands & 10 & 2.8 \\
7 & KU Leuven & 9 & 2.5 \\
8 & Technical University of Lisbon * & 9 & 2.5 \\
9 & Chinese Academy of Sciences & 8 & 2.2 \\
10 & University of Lisbon * & 8 & 2.2 \\
\hline
\end{tabular}

* In 2013, Technical University of Lisbon merged with the older University of Lisbon and was incorporated in the new University of Lisbon.

\subsubsection{Most Frequently Cited Papers}

The 10 most cited documents among the documents found in the bibliometric analysis are compiled in Table 5. The number of cites ranged from 215 for the paper in the 10th position to 1510 for the leader article. Prior to commentary on the most relevant research trends, which are introduced in the next section, the analysis of the most cited documents can provide a first idea about some of the important topics that have been considered essential for the researchers that investigate lignin valorization. Most documents in Table 5, 8 from 10, are reviews: three papers cover the valorization of lignocellulosic biomass and lignin from a broad perspective [2,32,33], while the other three documents review the catalytic lignin valorization $[8,34,35]$. The rest of the reviews focus on more specific topics: techno-economic analysis of bioethanol production [36], and biomass pretreatment with ionic liquids [37]. The remaining papers are two research articles related to lignin depolymerization, one based on the employment of formic acid [38], the other on metallic catalysts in alcohols [39]. 
Table 5. The top 10 most cited papers.

\begin{tabular}{|c|c|c|}
\hline Ranking & Documents & Times Cited \\
\hline 1 & $\begin{array}{c}\text { Title: The catalytic valorization of lignin for the production of renewable chemicals } \\
\text { Author(s): Zakzeski, J., Bruijnincx, P.C.A., Jongerius, A.L., Weckhuysen, B.M. } \\
\text { Source: Chemical Reviews } \\
\text { Published: } 2010\end{array}$ & 1510 \\
\hline 2 & $\begin{array}{c}\text { Title: Lignin valorization: Improving lignin processing in the biorefinery } \\
\text { Author(s): Ragauskas, A.J., Beckham, G.T., Biddy, M.J., Chandra, R., Chen, F. et al. } \\
\text { Source: Science } \\
\text { Published: } 2014\end{array}$ & 552 \\
\hline 3 & $\begin{array}{c}\text { Title: Valorization of biomass: Deriving more value from waste } \\
\text { Author(s): Tuck, C.O., Pérez, E., Horváth, I.T., Sheldon, R.A., Poliakoff, M. } \\
\text { Source: Science } \\
\text { Published: } 2012\end{array}$ & 529 \\
\hline 4 & $\begin{array}{l}\text { Title: Lignocellulose conversion: An introduction to chemistry, process, and } \\
\text { economics } \\
\text { Author(s): Lange, J.P. } \\
\text { Source: Biofuels, Bioproducts and Biorefining } \\
\text { Published: } 2007\end{array}$ & 294 \\
\hline 5 & $\begin{array}{l}\text { Title: Catalytic transformation of lignin for the production of chemicals and fuels } \\
\text { Author(s): Li, C., Zhao, X., Wang, A., Huber, G.W., Zhang, T. } \\
\text { Source: Chemical Reviews } \\
\text { Published: } 2014\end{array}$ & 291 \\
\hline 6 & $\begin{array}{c}\text { Title: Liquid fuels, hydrogen and chemicals from lignin: A critical review } \\
\text { Author(s): Azadi, P., Inderwildi, O.R., Farnood, R., King, D.A. } \\
\text { Source: Renewable and Sustainable Energy Reviews } \\
\text { Published: } 2013\end{array}$ & 286 \\
\hline 7 & $\begin{array}{l}\text { Title: Lignin depolymerization (LDP) in alcohol over nickel-based catalysts via a } \\
\text { fragmentation-hydrogenolysis process } \\
\text { Author(s): Song, Q., Wang, F., Cai, J., Wang, Y., Zhang, J., Yu, W., Xu, J. } \\
\text { Source: Energy and Environmental Science } \\
\text { Published: } 2013\end{array}$ & 257 \\
\hline 8 & $\begin{array}{c}\text { Title: Formic-acid-induced depolymerization of oxidized lignin to aromatics } \\
\text { Author(s): Rahimi, A., Ulbrich, A., Coon, J.J., Stahl, S.S. } \\
\text { Source: Nature } \\
\text { Published: } 2014\end{array}$ & 240 \\
\hline 9 & $\begin{array}{c}\text { Title: Techno-economic analysis of lignocellulosic ethanol: A review } \\
\text { Author(s): Gnansounou, E., Dauriat, A. } \\
\text { Source: Bioresource Technology } \\
\text { Published: } 2010\end{array}$ & 227 \\
\hline 10 & $\begin{array}{c}\text { Title: Advances on biomass pretreatment using ionic liquids: An overview } \\
\text { Author(s): Tadesse, H., Luque, R. } \\
\text { Source: Energy and Environmental Science } \\
\text { Published: } 2011\end{array}$ & 215 \\
\hline
\end{tabular}

\subsection{Analysis of Author Keywords and Hot Topics of the Research on Lignin Valorization}

The author keywords of a research document provide the information that the authors consider important to be highlighted and a statistical analysis of them helps to identify the research hotspot information of a particular field [40]. The most frequently used keywords, which were mentioned by at least 18 documents, are listed in Figure 2. Synonyms, spelling variants, and singular and plural forms were considered together to simplify the list. 


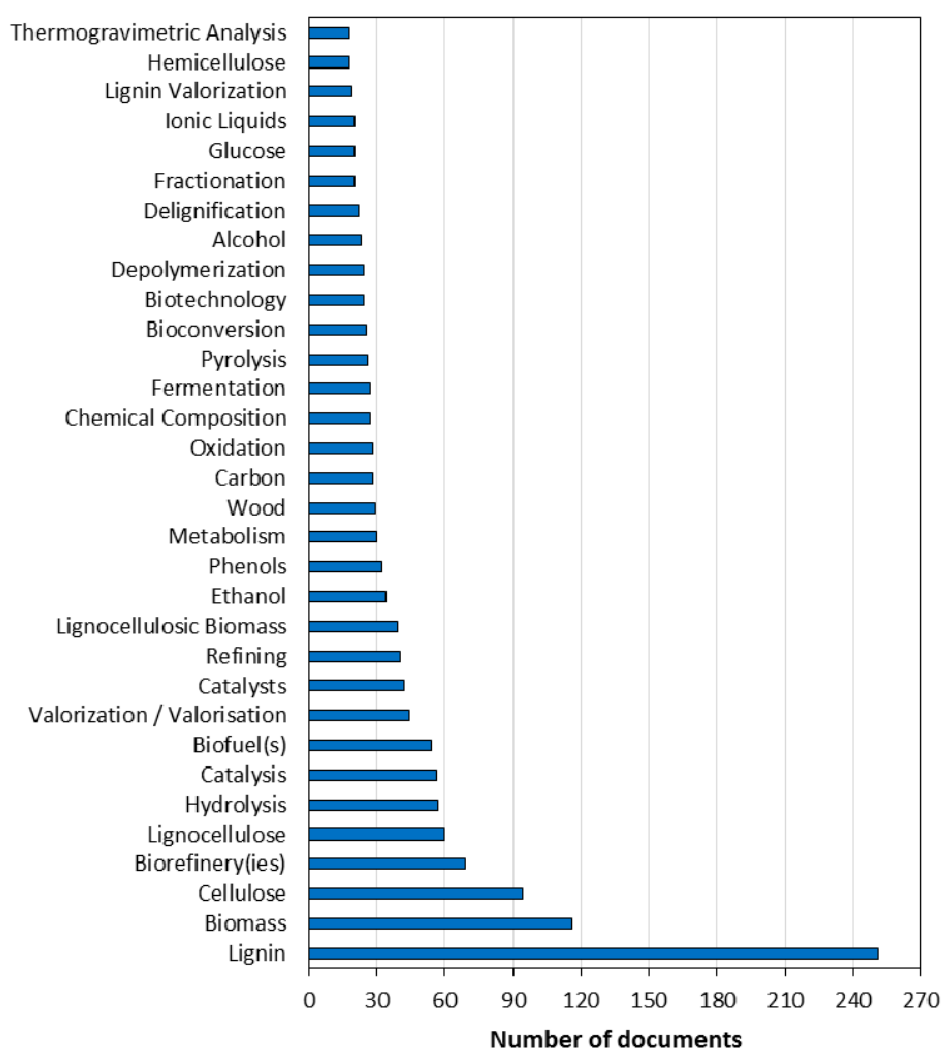

Figure 2. Most frequently used keywords.

The most frequently selected keyword was Lignin, with 245 appearances. As Lignin was one of the words employed in the search engine, it is quite logical to find it among the most common keywords. However, the other search word, Valorization, was only selected by 43 documents and the combination of both, Lignin valorization, appeared 19 times. The other two main components of lignocellulosic biomass appeared among the top keywords: Cellulose 94 times and Hemicellulose 18. Other related keywords were also frequent, such as Biomass (113 times), Lignocellulose (60 times), or Lignocellulosic biomass (39 times). As previously reported after the analysis of alternatives for hemicellulose valorization [22], the three components of lignocellulosic biomass are highly connected and the valorization of lignin must consider the integral biomass exploitation in biorefineries (Biorefinery(ies) was found among the most frequently used keywords, with 69 appearances).

An interesting group of top keywords refer to biomass processing. Among these keywords, Hydrolysis was the most represented, with 56 times, followed by Catalysis (53 times), and Refining (40 times). The list continued with other processes such as Oxidation (28 times), Fermentation (27 times), Pyrolysis (26 times), Bioconversion (25 times), Depolymerization (23 times), Delignification (22 times), or Fractionation (20 times). This great diversity of processes indicated that different options are available for biomass treatment in order to valorize lignin. Besides, some chemical compounds appeared among the most frequent keywords: Phenols (30 documents) and Carbon (27 documents). These chemicals can give a clear idea about the most relevant routes for the chemical valorization of lignin.

\section{Review of the Main Alternatives for Lignin Valorization and Current Trending Topics}

The high number of papers that cover lignin valorization, which have been identified by this work, introduces the research advances in the whole processing: the improvements in isolation, recovery, and characterization of lignin from biomass, the posterior depolymerization of lignin into monomers by chemical and biological means, and the final upgrading of the depolymerized lignin monomers to industrially relevant chemicals [41]. All these aspects have been deeply described by several 
reviews [42-57], and, therefore, the purpose of this section is just to summarize the most relevant trending topics, without the intention of compiling a detailed list of all the bibliography published.

\subsection{Lignin Structure, Isolation and Characterization}

Lignin is an extremely complex heterogeneous biopolymer formed by phenylpropanoid units derived from three monolignols: p-coumaryl alcohol (Hydroxyphenyl unit), coniferyl alcohol (Guaiacyl unit), and sinapyl alcohol (Syringyl unit). The lignin monomers are conjugated via different bonds that configure a polymer with high resistance to chemical and biochemical depolymerization. Ether linkages, especially $\beta$-aryl ether ( $\beta$-O-4), are most dominant in lignin. The $4-\mathrm{O}-5$ and $\alpha-\mathrm{O}-4$ aryl ether bonds are less predominant and other linkages, such as biphenyl linkages $5-5$, phenylcoumaran $\beta-5$, diarylpropane $\beta-1$ and $\beta-\beta$, are characteristic of the lignin structure (Figure 3). A variety of functional groups, including methoxyl, phenolic hydroxyl, aliphatic hydroxyl, benzyl alcohol, noncyclic benzyl ether, and carbonyl groups, determine the reactivity of lignin [58].

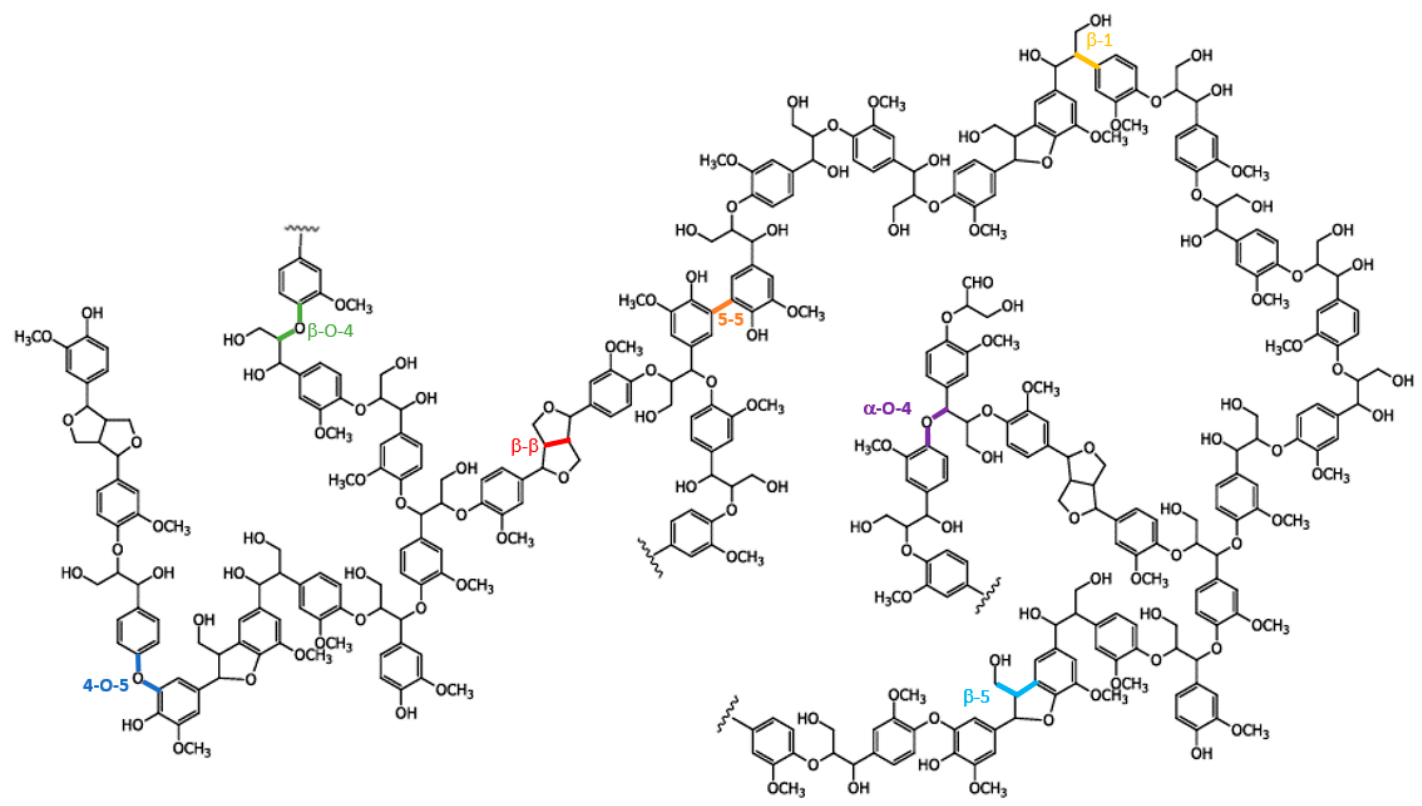

Figure 3. Example of a lignin structure with the typical $5-5, \beta-\beta, \beta-5, \beta-1, \beta-\mathrm{O}-4, \alpha-\mathrm{O}-4$, and $4-\mathrm{O}-5$ linkages (adapted scheme $[59,60]$ ). Reproduced with permission from Chávez-Sifontes, Lignina, estructura y aplicaciones: métodos de despolimerización para la obtención de derivados aromáticos de interés industrial; published by Avances en Ciencias e Ingeniería, 2013.

Various biomass pretreatments have been developed for the fractionation of the three main lignocellulosic components. Delignification is essential, because lignin causes problems in the processing of cellulose and hemicellulose [61]. Pulping techniques have been the traditional routes for lignocellulosic biomass pretreatment. However, they have been totally focused on obtaining delignified cellulose without paying attention to the other lignocellulosic components (hemicellulose and lignin). Even the production of biofuels has not considered the valorization of lignin and the main target of the pretreatment has been the preparation of lignocellulosic biomass for enzymatic hydrolysis of polysaccharides to fermentable sugars [62]. The recent consideration of all the components of lignocellulosic biomass as valuable renewable raw materials obliges a redefinition of the scenario. A biorefinery is a facility that integrates the biomass conversion processes to produce bioenergy, biofuels, and bio-based chemicals from biomass [22]. Biorefineries appear as the new paradigm for the sustainable management of lignocellulosic resources, where the simultaneous valorization of the three main components (hemicellulose, cellulose, and lignin) must be promoted. 
When focusing on the isolation of lignin for further valorization, the different methods that have been proposed for this purpose can be divided into two main categories. On the one hand, some methods are based on the hydrolysis of cellulose and hemicellulose to maintain lignin as an insoluble solid. On the other hand, the rest of methods are based on the dissolution of lignin while cellulose and hemicellulose remain in the insoluble residue [58]. The autohydrolysis and enzyme-based processes can be mentioned as examples of the first group, but most of the developed models correspond to the second group.

The Klason method is the most frequent procedure for quantitative lignin determination. Klason lignin is obtained by the depolymerization of cellulose and hemicelluloses in $72 \%$ sulfuric acid, followed by hydrolysis of the dissolved polysaccharides in diluted sulfuric acid (3\%) at higher temperature, although numerous modifications have been proposed over the years $[63,64]$. Cellulolytic enzymes can be employed to hydrolyze the carbohydrate fraction of lignocellulosic biomass, leaving an insoluble residue rich in lignin. Additional purification through neutral solvent extraction, followed by precipitation, gives as result cellulolytic enzyme lignin (CEL), which has been common subject of structural determination because of its representativeness of native lignin [65-67]. The cellulosic bioethanol plants can be designed to improve their economic competitiveness through the valorization of underutilized lignin-rich wastes as major feedstock for CEL [68-70]. Enzymatic mild acidolysis lignin (EMAL) is the result of a more sophisticated process to obtain a lignin that may be more representative of the total lignin with higher yield and purity [71,72]. Moreover, the yield and purities values can be increased by the use of microwaves after the enzymatic hydrolysis and purification by diluted acid extraction [73]. EMAL has been employed as a lignin model for the analysis of valorization routes, mainly by pyrolysis [74-77].

Regarding lignin dissolution, two different methods to obtain native lignin must be mentioned. On the one hand, milled wood lignin (MWL) is isolated by application of the Björkman process [78]. Finely milled wood, previously pretreated with organic solvents to remove the extractives, is treated with aqueous dioxane solutions. On the other hand, Brauns' lignin does require milling and can be obtained by extraction with ethanol from residual lignocellulosic biomass [79]. However, the yield of this process is too low, as less than $10 \%$ lignin can be isolated. Both methods continue as useful tools for investigations of lignin structure, reactivity, and biodegradability [80-84].

More technical lignin is obtained as a by-product by the pulp and paper industrial sector, but the different traditional pulping process has a great influence of the properties of the isolated lignin [85]. The Kraft process, based on the use of a hot mixture of water, sodium hydroxide, and sodium sulfide, gives as a result Kraft lignin. Lignosulfonates are obtained by the sulfite process, which employs sulfites and bisulfites. Finally, soda lignin, with properties quite similar to Kraft lignin but sulfur-free (Table 6), is produced by soda pulping just with sodium hydroxide. The transformation of existing pulp and paper mills into forest biorefineries is a valuable option to improve the sustainability of paper making with a simultaneous valorization of hemicellulose and lignin [86,87]. The potential of Kraft and soda lignins as feedstock for value added products has been investigated to identify the most adequate pulping conditions [88-90]. Moreover, alkaline delignification processes inspired by traditional pulping have been proposed for integral lignocellulosic biomass valorization [91-95].

Table 6. Properties of the main commercially available types of lignin (adapted [96]).

\begin{tabular}{cccc}
\hline Properties & Kraft Lignin & Lignosulfonate & Soda Lignin \\
\hline Molecular weight $\mathbf{M}_{\mathbf{W}}$ (Da) & $1500-5000$ & $1000-50,000$ & $1000-3000$ \\
Polydispersity & $2.5-3.5$ & $4.2-7.0$ & $2.5-3.5$ \\
Ash content (\%) & $0.5-3.0$ & $4.0-8.0$ & $0.7-2.3$ \\
Carbohydrate content (\%) & $1.0-2.3$ & - & $1.5-3.0$ \\
Sulfur content (\%) & $1.0-3.0$ & $3.5-8.0$ & 0 \\
Moisture (\%) & $4.0-9.0$ & $3.0-7.0$ & $2.5-3.5$ \\
\hline
\end{tabular}


The organosolv treatment is an alternative to conventional pulping processes. Lignocellulosic biomass is treated with organic solvents at a temperature between 150 and $200{ }^{\circ} \mathrm{C}$, with or without the addition of auxiliary catalysts (inorganic acids are the most common catalysts) [97]. The organosolv processes present many advantages over traditional pulping methods, like milder conditions, higher simplicity, non-sulfur formulas, and easier recycling of the organic solvents [98]. Moreover, total fractionation of lignocellulosic can be carried out to obtain cellulosic fibers for papermaking or easily digestible cellulose for bio-ethanol (depending of the treatment harshness), high quality sugars from hemicelluloses and lignin-derived products precipitated from the black liquors (Figure 4). However, nowadays there is not yet any full operating industrial-scale installation using the organosolv processes.

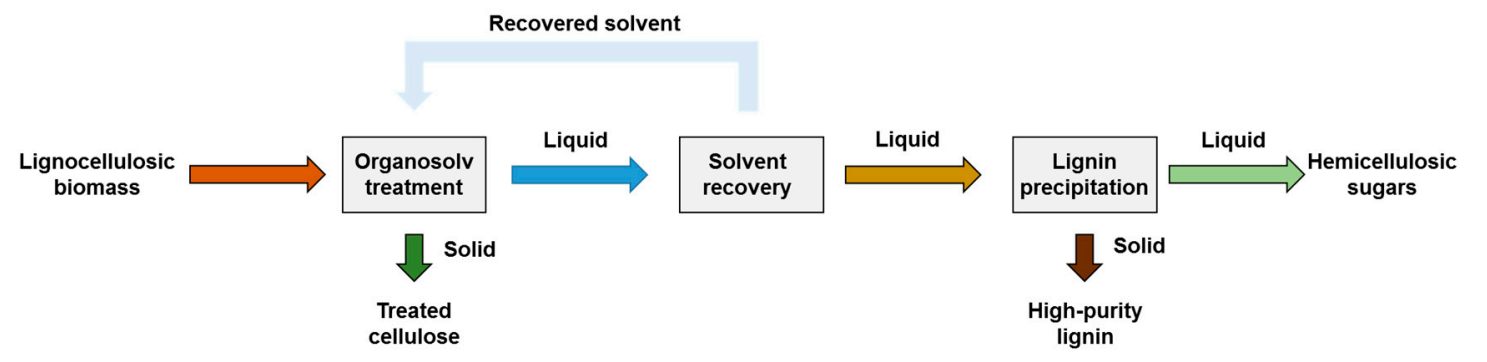

Figure 4. Scheme of lignocellulosic biomass fractionation by the organosolv process.

Organosolv processes have been gaining importance since the 1970s and have become a promising option for integral lignocellulosic biomass, as reviews published covering this topic demonstrate [99-101]. The selection of the most adequate organic solvent as delignifying agent for a specific type of biomass determines the organosolv process, but other relevant parameters, such as reaction time and temperature must be taken into account. In order to avoid excessive costs, the solvents employed for organosolv process must be bulk commodity chemicals. Low molecular weight alcohols have been preferred: ethanol appears as the most frequent solvent [102-106], but examples that use methanol [107-109], propanol [110-112], and butanol [113-115] can be found as well. Low molecular weight organic acids, mainly formic and acetic acids, are other relevant solvents for organosolv treatments [116-121] and include the optional addition of hydrogen peroxide to produce in situ performic and peracetic acids [122-124]. Many other solvents have been tested [125,126], but a new trend that must be mentioned is the application of solvents obtained from biomass. This is the case of two relevant chemicals: glycerol and gamma-valerolactone. On the one hand, the consideration of glycerol, a highly available and cheap byproduct of the industrial biodiesel sector, as a green solvent for organosolv processes has been proposed by several research groups [93,127-130]. On the other hand, gamma-valerolactone, which can be obtained from levulinic acid derived from hemicellulosic sugars, is an interesting solvent that can be applied to lignocellulosic biomass pretreatment [131-135].

More recent biomass treatments are based on the use of advanced solvents, such as ionic liquids (ILs) and deep eutectic solvents (DESs). The dissolution of lignocellulosic biomass in ILs has been extensively investigated [136]. Although the complete dissolution of the whole biomass has been tested $[137,138]$, the selective dissolution of its components has been more frequently proposed. Several ILs have demonstrated their effectiveness for lignin dissolution [139], but imidazolium-based ILs appear as the most representative examples [140-149]. As lignin can be selectively extracted from lignocellulosic biomass by employment of ILs, new simpler pretreatment methods can be developed for lignin isolation and purification $[150,151]$. Moreover, the complete fractionation of the biomass into the three main components has been carried out [152]. Nevertheless, the consideration of the technical, economic, and environmental aspects of IL-based pretreatments must be more deeply investigated, paying attention to the amount of solvent needed, the IL recovery processes, and the toxicity of these solvents as well $[37,153]$. DESs can be employed in innovative processes for biomass fractionation and a considerable number of papers covers their applicability in biomass 
processing [3,154]. To assess the potential of DESs as solvents for biomass delignification and further valorization of the isolated lignin, the study of the solubility of lignin in pure DESs and their aqueous solution has been performed [155]. Although alternative hydrogen bond acceptors (such as betaine, proline, or ethyl-ammonium salts) [156-160] have been evaluated, choline chloride has been most frequently investigated in combination with different hydrogen bond donors [161-168]. The obtained results have demonstrated that the fractionation methods based on DESs can provide new chances for lignin isolation with higher economic competitiveness and lower risks than the ones based on ILs [169].

Structural characteristics of lignin are highly dependent on the isolation method. Therefore, its posterior characterization reveals the intrinsic structural modifications lignin suffers after different biomass pretreatments [170]. The different characteristics determine the best valorization route of each lignin type. As lignin presents a highly complex polymeric structure with no regular sequences of the monomers, its composition and structure are generally characterized by the relative abundance of $\mathrm{H} / \mathrm{G} / \mathrm{S}$ units, the distribution of inter-unit linkages, the functional groups, as well as the degree of condensation in the polymeric structure [171]. Several analytical methods have been developed for lignin analysis to get qualitatively and quantitatively information. The composition, structure and functional groups of lignin can be determined by spectroscopic techniques. Lignin characterization has been improved by recent developments in Fourier-transform infrared (FT-IR) and 1D and 2D nuclear magnetic resonance (NMR) spectroscopy [172-176]. Among these methods, 2D NMR spectroscopy is the most powerful tool [177]. Methods for acquiring molecular weight key features (such as the number-average molecular weight $\mathrm{Mn}$, the weight-average molecular weight $\mathrm{Mw}$, and the polydispersity index PDI), which have great influence on the properties and possible applications of lignin, have evolved very fast [178]. Although several alternative instrumental techniques are available [179], the well-known size exclusion chromatography (SEC) appear as the most preferred option [180-182]. The study of the thermal degradation of lignin by thermogravimetric analysis (TGA) is important to have a better knowledge of the underlying decomposition behavior [88]. The thermal stability of lignin provides additional information about its structure and helps to identify optimal biomass conversion processes, particularly when focused on energy and materials [119,183]. Moreover, differential scanning calorimetry (DSC) is employed to determine the softening and glass transition temperatures of lignin, which is useful information to avoid inappropriate temperature profiles to process lignin $[184,185]$. More recently, the characterization of the biological properties of lignin has gained importance. The literature that has characterized and evaluated the biological properties of lignin has become common since 2010 [186]. The antioxidant, antimicrobial, anti-inflammatory, antiviral, antimutagenic and antidiabetic properties have been identified as the most relevant biological characteristics for pharmaceutical, nutraceutical, and other industrial applications of lignin $[187,188]$.

\subsection{Thermochemical Depolymerization}

A significant amount of research papers have investigated different lignin depolymerization processes (Figure 5) [8]. During lignocellulosic biomass fractionation, the separated lignin must be broken into smaller molecular units to obtain lower-molecular-weight monomeric and oligomeric components [189]. Most depolymerization methods have focused on the selective cleavage of the $\beta-\mathrm{O}-4$ bond, but the cleavage of other types of linkages in lignin must be considered. Nevertheless, the quality, molecular weight distribution, solubility, reactivity, and structure of the isolated lignin differ strongly depending on the raw material and the processing methods, so the most adequate depolymerization process cannot be easily standardized [190]. Moreover, the different target end products must be taken into account to select the optimal depolymerization option. 


\section{LIGNIN DEPOLYMERIZATION}
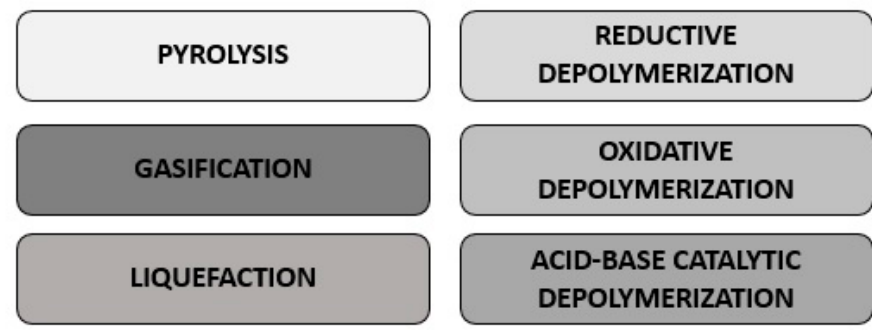

Figure 5. Thermochemical processes for lignin depolymerization.

\subsubsection{Pyrolysis}

Pyrolysis is a relatively simple thermochemical process to break down lignin into low molecular weight compounds. It consists in heating raw or pretreated biomass in the absence of oxygen to decompose the organic fraction into releasing gases and a residual solid (biochar) [191]. When cooling is applied to the releasing gases, polar condensable compounds can be recovered as a liquid (bio-oil), while non-condensable volatile compounds remain in the gas phase (pyrolytic gas). This pyrolytic gas, which may consist of carbon dioxide, carbon monoxide, hydrogen, and short hydrocarbons, such as methane, ethane or ethylene, with small amounts of other gases, can be directly combusted to produce the heat required for the pyrolysis process. The obtained biochar can be employed to produce biomass-based carbon materials, but bio-oil is the most desired fraction, as it can be upgraded to fuels or other relevant chemicals. Further information about the properties and applications of the pyrolysis products derived from lignocellulosic biomass can be consulted [192].

Although one of the most attractive advantages of pyrolysis is the high potential of several usable products from a wide variety of feedstocks, the biomass type and composition have great influence over the pyrolysis process and the resulting fractions [193]. Whereas cellulose and hemicellulose contribute to higher bio-oil production yield, lignin results in a higher proportion of biochar [194]. Nevertheless, as lignocellulosic biomass should be pretreated before the pyrolytic process, fractionation should be preferred to target only the lignin-rich biomass fraction to pyrolysis, with alternative and valuable routes for the cellulosic and hemicellulosic fractions. Recent studies have demonstrated the high suitability of the lignin-rich residues obtained after enzymatic saccharification of woody biomass for pyrolysis [195-197]. Moreover, residual lignocellulosic biomass, such as barks, stalks, husks, seeds, shells, pits, cobs, or piths, has been identified as an adequate candidate for pyrolytic valorization, since the fractionation of this type of biological waste lacks interest [198-203]. Another option that has been investigated is the staged thermal fractionation of lignocellulosic biomass, which results in simpler streams than the direct pyrolysis of the biomass [204]. Since the different main components of lignocellulosic biomass decompose at different temperatures, different pyrolysis product fractions can be obtained by sequentially increasing temperature profiles [205]. These simpler fractions are more easily upgraded and the determination of the optimal thermal profile must take into consideration the relative abundances of the different compounds in the fractions to be upgraded [206,207].

The influence of the pyrolysis operation conditions over the process performance has been deeply analyzed. The temperature and heating rate are fundamental parameters, as they define three different types of pyrolysis: slow, fast, and flash pyrolysis [208]. As slow pyrolysis promotes the formation of charcoal, fast and flash pyrolysis are preferred for bio-oil production. Fast pyrolysis typically involves high heating rates $\left(10-200{ }^{\circ} \mathrm{C} / \mathrm{s}\right)$ and short residence times $(0.5-10 \mathrm{~s})$ [209]. Flash pyrolysis is characterized by even higher heating rates and shorter residence times (below $0.5 \mathrm{~s}$ ), resulting in high bio-oil yield [210]. This shorter residence time favors bio-oil production due to the fast 
removal of the vapor phase from the reactor, which minimizes the secondary undesired reactions. At the lab scale, biomass pyrolysis is performed in most cases under inert nitrogen atmosphere [211], but in industrial applications other gases can be also employed as carriers to modify the pyrolysis process. The most investigated reactive gases are the common gaseous products (carbon monoxide, hydrogen, and methane) found in the non-condensable gas fraction obtained from the pyrolysis of lignocellulosic biomass. The recirculation of this pyrolytic gas resulted in upgraded bio-oils as a result of lower methoxy-containing compounds and a higher proportion of monofunctional phenols in the bio-oils [212,213]. Moreover, the presence of steam, which can weakly oxidize the biomass and avoid secondary cracking reactions in the gas phase, increases the bio-oil and gas yields significantly [214,215]. Another option to enhance the yield of monomeric phenols in bio-oils has been proposed: catalytic pyrolysis technologies $[216,217]$. The addition of a catalyst to the pyrolysis reactor favors the control of the product distribution to more desired compounds. Zeolites are the most preferred catalysts for catalytic pyrolysis $[218,219]$. Moreover, when ammonia is used as a carrier, zeolites can catalyze the production of aromatic amines, which can be considered major building blocks and key intermediates, from pyrolyzed lignin [220].

Important research efforts have been focused on the analysis of the lignin pyrolysis kinetics. A better understanding of the reaction kinetics helps to predict the pyrolysis behavior and identify the optimal parameters of the pyrolytic processes. The results of the thermogravimetric analysis of lignocellulosic biomass or isolated lignin can be employed to determine the thermal stability and model the pyrolysis kinetics [221]. The development of simple lumped models has been a frequent approach. These simple models can be considered adequate for studying different kinds of lignocellulosic materials, since good fitting among experimental and modelled data are obtained [222-224]. However, these lumped models lack the detail and flexibility necessary to be employed in the optimization of real-case industrial processes. More detailed kinetic models based on comprehensive mechanism schemes are required to cover a wider range of feedstocks and reaction conditions $[225,226]$. A complete review of the developed pyrolysis pathways, mechanisms, and kinetics models can be consulted [227].

\subsubsection{Gasification}

Conventional coal gasification technology can be redefined to use lignocellulosic biomass as raw material. This way, partial combustion of biomass by controlling the amount of oxidizing agent transforms hydrocarbons into synthesis gas (also called syngas, it is a mixture of carbon monoxide, carbon dioxide, and hydrogen), which can be easily transformed to Fischer-Tropsch fuels, dimethyl ether (DME), or methanol [228]. The biomass composition has great influence on the performance of the gasification process and the characteristics of the produced syngas. Compared with lignin, cellulose and hemicellulose produce gases more rapidly with higher carbon monoxide content, but lignin produces more hydrogen than the other components [229]. However, materials with high lignin content present more complications to gasification as a consequence of its recalcitrant nature, which tends to form more stable carbonaceous structures [230].

Gasification of lignin or lignin-rich fractions of biomass does not require previous drying and the needed temperatures are lower than other thermal processes, such as reforming [231]. Different oxidizing agents can be employed for the gasification: wet air [232,233], oxygen [234,235], steam [236,237], or supercritical water [238-240]. The alkaline and alkaline-earth metals present in mineral species existing in biomass have catalytic effects during biomass gasification [229,230,237,241]. Nevertheless, compared with homogeneous alkali catalysis [242], heterogeneous catalysts based on transition and noble metals have advantages. $\mathrm{Ni}-\mathrm{Co} / \mathrm{Mg}-\mathrm{Al}$ catalysts have been evaluated and have demonstrated high flexibility and potential for gasification [243], while noble metals showed higher activity for the gasification, following this order: $\mathrm{Ru}>\mathrm{Rh}>\mathrm{Pt}>\mathrm{Pd}>\mathrm{Ni}$ [244-247]. All the component technologies needed for the production of biofuels or chemicals through gasification at a biorefinery are either already commercially used or are undergoing pilot-scale demonstrations (Figure 6) and the 
corresponding technical and economic models have been developed for the simulation and evaluation of the complete process [248-250].

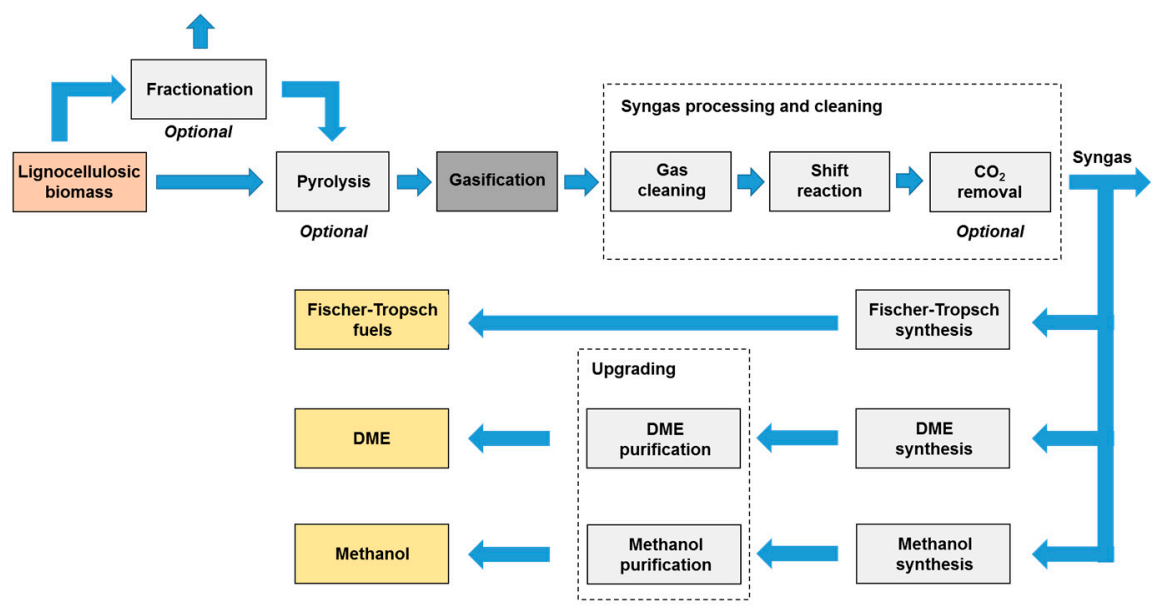

Figure 6. Schematic process from lignocellulosic biomass to fuels and chemicals through gasification.

\subsubsection{Liquefaction (Solvolysis)}

While lignin can be at least partially dissolved from biomass under appropriate delignification conditions, the production of monomeric compounds with direct valorization is not usual during these extraction processes [251]. Therefore, further depolymerization of the obtained oligomers is required. Different solvents can cleave the lignin intermolecular linkages under more rigorous processing conditions.

Sub-critical and super-critical water can depolymerize lignin into its derivative compounds by dealkylation and hydrolysis reactions. The sub-critical $\left(170-400{ }^{\circ} \mathrm{C}\right.$ and $\left.5-25 \mathrm{MPa}\right)$ hydrothermal processes obtain relatively narrow product spectra and reasonable yields of phenolic products without the employment of other solvents (and subsequent recovery or disposal problems) [252]. The higher $\mathrm{H}^{+}$ and $\mathrm{OH}^{-}$concentrations in sub-critical water make water a reagent, as well as a solvent, and promote the recovery of valuable phenolic compounds [1]. Under super-critical $\left(>400{ }^{\circ} \mathrm{C}\right.$ and $\left.25-40 \mathrm{MPa}\right)$ conditions, where water acts like a dense gas, oxidative pathways are also possible and the formation of char as a result of re-polymerization is minimized [253,254]. The hydrothermal depolymerization of model compounds has been useful, since it allowed the elaboration of models able to predict the process performance in terms of product yields [255]. Moreover, formal kinetic models have been developed, including the estimation of the corresponding activation energy and kinetic rate coefficients [256]. This model identified the bottlenecks of lignin hydrothermal depolymerization and the prevalent reactions.

Although lignin depolymerization has been carried out in aqueous media and organic solvents, only limited organic solvents have been tested. Solvolysis of lignin by alcohols is the most common alternative, in particular lignin solvolysis by ethanol, which can be considered an interesting system for integration into biorefineries since both lignin and ethanol are typical product streams from lignocellulosic biomass. Simple noncatalytic solvolysis of biorefinery lignin in supercritical ethanol can produce a heptane soluble bio-oil without the need for the addition of a catalyst or a reducing agent [257]. The catalytic ethanolysis of lignin proposes the use of different catalysts: precious group metals (Pd, Pt, Ru, Rh ... ) and more abundant metals $(\mathrm{Cu}, \mathrm{Ni}, \mathrm{Mo} \ldots$.. ) supported over oxides (alumina, ceria, zirconia, magnesia ... ) have been frequently reported [258-261], but alternative catalysts have been tested as well, such as silicon carbon nanoparticles [262] or ionic liquids [263]. Methanol have replaced ethanol in aqueous mixtures for lignin solvolysis with very similar results [264], while propanol and butanol have also been proposed [265]. Apart from alcohols, other organic solvents 
tested for direct lignin liquefaction must be mentioned, such as acetone, phenol, glycerol, ethylene glycol, dimethyl sulfoxide, and dimethyl formamide [198,266-268].

In addition to the employment of advanced solvents, such as ionic liquids (ILs) and deep eutectic solvents (DESs), for lignocellulosic biomass pretreatment and fractionation, this type of solvent can be used for lignin depolymerization. Most research efforts in converting lignin to its monomeric products using ILs have pointed to technical lignins extracted from lignocellulosic biomass [269]. The same ILs tested for biomass pretreatment have been evaluated for lignin depolymerization, so imidazolium-based ILs have been deeply investigated. At temperatures above $100{ }^{\circ} \mathrm{C}$, these ILs were able to break specific lignin linkages, like $\beta-O-4, \beta-\beta$ and $\beta-5$, and favored demethoxylation reactions [270]. Furthermore, posterior recondensation reactions were minimized when compared to non-imidazolium based ILs [271], with bio-based ILs with cholinium as cation as example [272]. However, the obtained monomers can be strongly solvated by the ILs, which impedes their easy precipitation and requires additional recovery stages [273]. The electrocatalytic depolymerization of lignin dissolved in inexpensive protic and aprotic ILs has been investigated [274,275]. The distribution and yield of the monomeric species depended strongly on the implemented metal electrodes, the IL nature and cell voltage; but the synergistic effects of the proposed approach appeared promising. Further information about the application of ILs as solvents and catalysts for lignin depolymerization can be consulted in the bibliography [276]. In the case of DESs, the selective cleavage of lignin $\beta-O-4$ linkage has been proposed as the main mechanism of depolymerization by acidic DESs [162,169], whereas neutral DESs favored the cleavage of methoxy moieties at the aromatic ring of lignin without significant depolymerization [277]. In a similar way to ILs, some electrocatalytic tests for lignin depolymerization have been performed with emulsified DES [278]. When nickel was selected as electrocatalyst, a decrease of the apparent average molecular weight of lignin was achieved, while graphite electrodes were not effective.

\subsubsection{Reductive Depolymerization (Hydrogenolysis)}

The reductive depolymerization of lignin, also called hydrogenolysis, is based on the selective cleavage of $\mathrm{C}-\mathrm{O}$ bonds by means of molecular hydrogen or other sources of active hydrogen. Although lignin hydrogenolysis was reported before the 1940s [279], it has not been more deeply investigated until recently, when improved metallic catalysts have been employed (a complete revision of the catalysts employed for lignin hydrogenolysis can be consulted in the bibliography) [280]. The hydrogenolysis removes oxygen-containing functional groups by breaking the C-O bonds and facilitates the posterior transformation of depolymerized lignin. Moreover, the hydrogenolysis minimizes the condensation reactions [281], particularly when auxiliary stabilizing agents, like formaldehyde, are employed [282]. The role of the solvents is a key aspect for the reductive depolymerization of lignin, as different solvents exhibit quite different results. Alcohols have been frequently employed as hydrogenolysis solvents and showed outstanding characteristics. Alcohols, acting as nucleophilic agents, collaborate to cleave C-O-C bonds and can function as the source of active hydrogen in a hydrogenolysis reaction without gaseous hydrogen. Methanol has been the most widely selected solvent [10,283-285], but other alcohols, such as propanol, ethanol, or glycerol, have been tested as well $[39,286,287]$. Apart from alcohols, polar aprotic solvents, like tetrahydrofuran or dioxane, and non-polar solvents, like cyclohexane, have been applied to the reductive deconstruction of lignin, appearing advantageous in terms of higher selectivity for specific depolymerization products [288]. In order to improve the operability of these processes, mild reaction conditions without the addition of molecular hydrogen or alcohols as solvents have been proposed. Alternative hydrogen donating solvents, such as formic acid and tetralin, have demonstrated the viability of the production of promising depolymerization products without the hazards related to high-pressure molecular hydrogen, under mild reaction conditions (temperatures below $150{ }^{\circ} \mathrm{C}$ and reaction times no longer than $30 \mathrm{~min}$ ) $[289,290]$. Nevertheless, the different catalysts, reducing agents, operation conditions and mechanisms reported complicate the direct comparison of the proposed 
processes and the identification of optimal solutions. Systematical analysis of the thermodynamics of hydrogenolysis of typical functional groups found in lignin have been applied to identify the mildest operation conditions. As a result, the theoretical foundation for the feasibility of designing novel reactions was provided, which demonstrated that new green catalysts, like transition metal catalysts, will allow lignin hydrogenolysis near ideal mild conditions (room temperature, room pressure, and aqueous solvent) [291]. For further information about the state-of-the-art of selective lignin hydrogenolysis, a very interesting published perspective can be consulted in [292].

\subsubsection{Oxidative Depolymerization}

Oxidative depolymerization of lignin uses oxidizing agents, such as potassium permanganate, nitrobenzene, hydrogen peroxide, or molecular oxygen to break $\mathrm{C}-\mathrm{C}$ and $\mathrm{C}-\mathrm{O}$ bonds in the lignin structure [293]. These oxidizing agents are derived in different intermediate oxygen-based radical species, which produced the formation of a wide variety of products. Therefore, the addition of catalysts was necessary in order to improve the selectivity for the most interesting monomeric aromatic compounds. When molecular oxygen was employed, the typical reaction conditions included alkaline solutions and metallic salts. However, homogenous catalysts, most of them based on organometallic compounds, have reported interesting results [294-296], although their low stability and difficult recyclability must be mentioned as relevant drawbacks. Moreover, the employment of unconventional activation methods (sonication, microwaves, electrocatalysis, photocatalysis ... ) and reaction media (supercritical fluids, ionic liquids ... ) has gained much attention, mainly because a better control of the product formation is allowed by limiting the problems of recondensation and repolymerization [297]. The mechanisms and role of electronic interactions contributing to selective cleavage of C-C and $\mathrm{C}-\mathrm{O}$ bonds between aromatic rings with simultaneous preservation of the aromaticity have been deeply investigated to identify the most adequate catalysts and reaction conditions $(\mathrm{pH}$, temperature, atmosphere ... ) [298,299].

\subsubsection{Acid or Base Catalytic Depolymerization}

The employment of acids, such as $\mathrm{H}_{2} \mathrm{SO}_{4}$ or $\mathrm{H}_{3} \mathrm{PO}_{4}$, have been useful to increase the efficiency of the fractionation processes of lignocellulosic biomass due to enhanced delignification. An important function of this catalysis is the improved extraction of lignin from the biomass, which is a relatively slow step [300]. In addition to this acid-catalyzed delignification, acidolysis is one of the oldest catalytic methods for lignin depolymerization [301]. The hydrolytic cleavages of $\alpha-\mathrm{O}-4$ and $\beta-\mathrm{O}-4$ linkages play a dominant role because other ether bonds, the phenolic $\mathrm{C}-\mathrm{O}$ bonds, and $\mathrm{C}-\mathrm{C}$ bonds between aromatic lignin units are more resistant to acids. However, the acid-catalyzed reactions result in styryl ethers and aldehyde formation, which are highly susceptible to recondensation, leading to higher molecular weight products, in some cases even more recalcitrant than the original lignin [302]. The use of trapping agents, like ethylene glycol, that sequester the released aldehydes highly improved the acidolysis process [303]. Traditional dilute acid-induced depolymerization (1-2\% mineral acid loading) has been performed under moderate temperatures and relatively short times $\left(120-180^{\circ} \mathrm{C}\right.$ and no longer than $2 \mathrm{~min}$ [ [304]. The use of biomass-derived simple carboxylic acids for lignin acidolysis have also been receiving attention. Formic and acetic acids can be produced from biomass under certain conditions. Formic acid, frequently in combination with sodium formate [38,305], resulted in effective lignin depolymerization. Formic acid acted as a hydrogen donor solvent and contributed with reductive mechanisms to lignin depolymerization [306]. By contrast, another organic acid, such as peracetic acid, has been employed for lignin acidolysis with supplementary oxidative mechanisms [307]. In addition, solid Brønsted acid catalysts, which have been widely employed in oil refineries, have also been considered for the depolymerization of lignin. Amorphous silica-alumina and zeolites resulted in satisfactory lignin conversion values and provided high aromatic yields [308]. The role of Lewis acid catalysts for the depolymerization of lignin has been more recently investigated. While $\mathrm{Fe}, \mathrm{Cu}, \mathrm{Ni}$, and 
$\mathrm{Al}$ chlorides were initially the preferred catalysts [309-311], while metal triflates have achieved higher degrees of depolymerization of lignin [312].

Base-catalyzed depolymerization of lignin has been proposed to depolymerize lignin extracted by different means from a wide variety of lignocellulosic feedstocks (hardwoods, softwoods, and grasses), including lignin-rich residues from the biorefinery processes [313]. This depolymerization process offers the economic advantage of using strong bases, which are cheap chemicals. Although studies that have investigated the effect of alternative bases, like $\mathrm{KOH}, \mathrm{Ca}(\mathrm{OH})_{2}, \mathrm{LiOH}$, or $\mathrm{K}_{2} \mathrm{CO}_{3}$, have been performed, the results demonstrated that $\mathrm{NaOH}$ showed the maximal depolymerization activity due to its strong strength [314]. The control of the reaction parameters (temperature, pressure, residence time, base concentration or biomass loading) allows the adjustment of the process yield and the distribution of lignin monomers and oligomers. Proposed optimal conditions include high temperatures $\left(240-340{ }^{\circ} \mathrm{C}\right)$ and pressures (30-250 bar) and base concentrations in the $2-10 \%$ range $[315,316]$. However, some relevant drawbacks, due to the use of strong bases, must be mentioned, which include mainly the high corrosivity and the impossibility of recovery of the homogenous catalysts. Therefore, solid base catalysts have been tested for lignin depolymerization: alkali and alkaline earth metal oxides, rare earth metal oxides, layered double hydroxides or exchanged zeolites and clays. Layered double hydroxides and zeolites have shown interesting results, since in addition to their inherent catalytic activity as solid bases, they can act as supports for other catalysts [317]. Although some researchers have suggested that alkaline depolymerization consists mainly in lignin oxidation by the cleavage of the $\beta-\mathrm{O}-4$ ether bonds [318], evidences show that ether bonds are hydrolyzed at random, most likely from the outside of the lignin oligomers, while simultaneous C-C bond cleavage occurs [319-321]. Further information about the mechanistic aspects of the based-catalyzed depolymerization of lignin, even with computational models providing atomistic details, can be consulted in the bibliography $[322,323]$. Recondensation reactions reduced the process yield, particularly when increased severity reaction conditions were applied, as monomeric products decreased with high temperatures and residence times [324]. The use capping agents to prevent these repolymerization reactions improved the processes, and several chemicals have been identified for this purpose. Phenol has been proposed as a good capping agent, but the addition of methanol, ethanol, formaldehyde, or boric acid, can prevent these reactions and promote the formation of stable monomeric products $[318,319,325]$. In order to reduce the energy intensiveness of the alkaline depolymerization processes, the use of ultrasonic pretreatment and microwave reactors has been evaluated [326]. While no significant effect was observed with the ultrasonic pretreatment, the use of a microwave reactor resulted in different liquid products when compared to traditional batch reaction, may be due to different reaction pathways.

\subsection{Chemical Conversion of Depolymerized Lignin}

Catalysis is a key element for transformation of depolymerized lignin fragments into valuable chemicals. The development of different catalysts and processes to valorize lignin has resulted in several approaches and strategies for catalytic conversion. These options include lignin reduction reactions, used to make fuels, and aromatic and phenolic compounds; lignin oxidation reactions, used to make functionalized aromatics; and additional functionalization reactions. Several reviews have compiled the most relevant research on lignin upgrading and on the processes aiming at its valorization [34,299,327-331].

\subsubsection{Reductive Conversion}

The wide variety of phenolic monomers and oligomers obtained after lignin depolymerization retains high oxygen content, which limits severely their direct application [332]. The oxygenated functional groups provide undesirable physicochemical properties, such as low thermal and chemical stability, high density, easy corrosiveness and low heating value as fuel. Therefore, these lignin-derived bio-oils are not compatible for direct mixture with petroleum-derived fractions and efficient processes 
for upgrading are required [333]. Reductive treatments are among the most promising and interesting technologies for bio-oil refining by removal of the chemically bonded oxygen [334]. The reduction of alcohols and carbonyls to produce alkanes are important in the context of biomass conversion to fuels and platform chemicals [335]. There is a well-known competition between the hydrogenolysis of $\mathrm{C}-\mathrm{O}$ bonds and the hydrogenation of the aromatic rings during the lignin hydrodeoxygenation. Unfortunately, the latter is thermodynamically favored and, as a result, the design of new functional catalysts with high selectivity has been considered crucial to overcome this situation [336].

Various catalytic processes have already been developed to selectively remove hydroxyl and methoxy oxygen-containing functional groups via hydrodeoxygention reactions [337-340]. Traditional catalysts for hydrodesulfurization and hydrodenitrogenation of petroleum products, such as sulfide $\mathrm{CoMo} / \mathrm{Al}_{2} \mathrm{O}_{3}$ and sulfide $\mathrm{NiMo} / \gamma-\mathrm{Al}_{2} \mathrm{O}_{3}$, have been tested for catalytic upgrading of bio-oils derived from lignin [341]. As sulfide catalysts present some disadvantages, catalysts based on noble metals appeared as a more suitable alternative, with examples using $\mathrm{Pt}, \mathrm{Pd}, \mathrm{Ru}$, and $\mathrm{Rh}$ [334]. The nature of the catalytically active metal, as well as the nature of the support and its acidity, has great influence on the process performance. Many different supports have been investigated, including alumina, silica, Kaolin, active carbon, and molecular sieves. Some reviews that analyze in detail and compare the processes with different catalysts have been published, taking into consideration their mechanisms, kinetics, and deactivation [327,330,342]. Apart from the catalyst, the other main parameters that affect the activity and product distribution of reductive upgrading of the depolymerized lignin are temperature and pressure [343]. Because the solubility of hydrogen gas in many organic solvents is low, high temperatures and excessive pressures of hydrogen are often required for these reactions [335]. The use of alternative hydrogen donors, for example organic alcohols like ethanol, has been proposed to improve safety concerns and reduce operational complexity, since they serve as the reaction solvent as well [344-346].

\subsubsection{Oxidative Conversion}

Oxidation has been the most frequent degradation chemistry employed in commercial pulping and bleaching processes. Oxidative lignin depolymerization is based on the cleavage of C-O and C-C bonds between the phenylpropanoid units, but oxidation reactions can be useful for lignin upgrading via side-chain oxidative modifications or oxidation of the aromatic rings and their cleavage [299]. Compared to reductive conversion, oxidation transforms lignin to more complicated chemicals with extensive functionality [34]. Most of these chemicals can be considered as low molecular weight phenolic compounds, some of which have direct application as end products, while the rest are valuable platform chemicals. Apart from this type of compound, oxidation of depolymerized lignin has been proposed for the production of carboxylic (formic, acetic ... ) and dicarboxylic (muconic, maleic, succinic, malonic ... ) acids [347,348]. Since elemental chlorine-free paper took the use of chlorine off the pulping sector, this oxidant has not been taken into account for lignin oxidation and has been replaced by wet air [349-351], steam [352-354], pure oxygen [355,356], ozone [357-359], hydrogen peroxide [360-362], and peroxy acids [363]. Research studies have discovered that the employed oxidant reagent had a significant effect for the production of some particular chemicals (vanillin for example), but it was not relevant for others [364].

Nevertheless, the most investigated topic within oxidative upgrading of lignin oxidation has been the catalytic chemistry provided by a wide variety of catalysts [365]. Inorganic catalysts, such as metals, metal oxides or polyoxometalates, are commonly used for oxidizing organic substrates and have been evaluated for lignin upgrading. Among metals, noble metals like palladium can be highlighted [366,367], while $\mathrm{CuO}, \mathrm{Mn}_{3} \mathrm{O}_{4}$ and $\mathrm{CoO}_{3}$ can be mentioned as examples of metal oxides $[368,369]$. Two different polyoxometalates, phosphomolybdic and phosphotungstic acids, have shown different catalytic behaviors and the reaction pathways of lignin oxidation to carboxylic acids [348]. Inspired on natural enzymes, taking manganese peroxidase as the most illustrative example, biomimetic catalysts with metallic core and organic ligands have been tested 
for lignin oxidative conversion. The mechanisms of phenolic compound oxidation mediated by metallosalen complexes (salen ligands with metallic ions, mainly copper and cobalt) have been deeply investigated and advanced systems for improved activity have been developed by means of improved immobilization techniques or preparation of salen-type metal complexes tagged with ionic liquid cores [370-372]. The selective aerobic cleavage of C-C bonds and the oxidation of phenolic alcohols into their corresponding aldehydes or ketones by vanadium complexes has been reported [373-375]. Organic compounds with sulfur, nitrogen, and phosphor atoms can catalyze oxidation reactions and some of them present higher selectivity and efficiency than other catalysts for lignin oxidation. Among these organocatalysts, chemicals based on TEMPO (2,2,6,6-tetramethylpiperidine-1-oxyl) have been the most investigated cases for chemoselective oxidation of lignin. They have been applied to the conversion of primary and secondary alcohols to aldehydes, ketones, or carboxylic acids [376-378].

\subsubsection{Functionalization of Hydroxyl Groups and Introduction of Other Functional Groups}

From the original phenolic hydroxyl groups and aliphatic hydroxyl groups present in raw lignin, the phenolic hydroxyl groups remain as the most reactive functional groups and determine the chemical reactivity of the depolymerized lignin fragments. Modifications on these hydroxyl groups by different reactions can lead to the formation of valuable chemicals (Figure 7). Reactions such as alkylation, etherification, esterification, phenolation, and urethanization have been applied to functionalize the lignin with different useful functional groups.

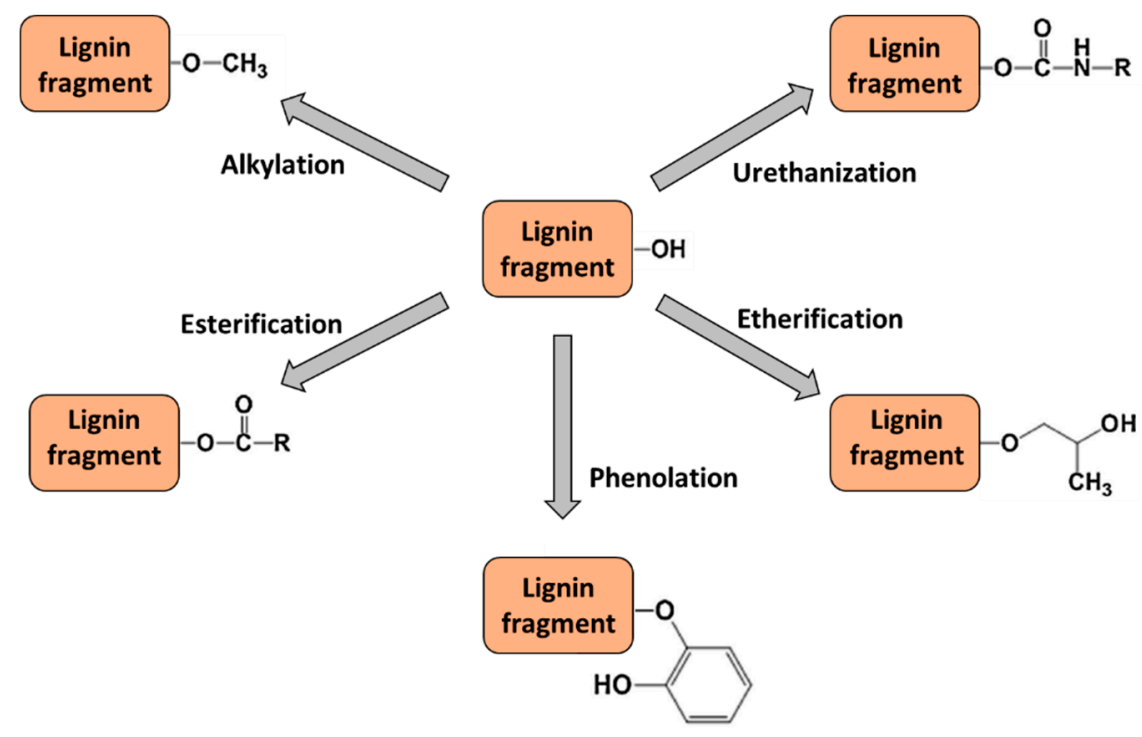

Figure 7. Chemical modifications of depolymerized lignin by functionalization of the hydroxyl groups.

There are different methods for alkylating lignin fragments. Although the use of diazoalkanes or alkylsulfates has been mentioned [379], the catalytic reaction with alcohols or ethers is a more frequent option [380-382]. The oxypropylation is the most used etherification method to modify lignin using propylene oxide in the presence of an alkaline solution, in order to prepare lignin-based epoxy resins [383]. The esterification is one of the most practical functionalization reactions, since lignin-based polyesters can be employed for polymer production, in most cases forming part of polymer blends [384-386]. Phenolation implies lignin reaction with phenol in organic acid medium. This increase of the content of phenol groups improves the reactivity of the lignin fragments and the resulting fragments can then react with formaldehyde to produce phenol-formaldehyde resins [387-389]. Lignin hydroxyl groups can react with isocyanate groups to form urethane links, which can be incorporated in polyurethane formulations [390,391]. 
Apart from functionalization of the existing hydroxyl groups, different pathways for chemical modification have been proposed to introduce new chemical active sites in the lignin chemical structure. For example, nitration, amination, dealkylation, carboxylation or halogenation have been investigated, although less extensively than reactions involving hydroxyl groups [331]. Alkylation must be mentioned as well among the reactions for synthesis of new chemical active sites, since, besides hydroxyl groups, oxygen atoms of the carbonyl and carboxyl groups or carbon atoms of the aromatic rings are susceptible to alkylation [329].

\subsection{Biological and Biochemical Processes}

Biological and biochemical strategies are highly promising for lignin valorization, since they can overcome the high heterogeneity of lignin better than traditional chemical strategies [392]. Lignin depolymerization and catabolism of the obtained aromatic compounds offer a route that should be considered equivalent to the more consolidated approach for biomass-derived polysaccharide depolymerization and fermentation or chemical conversion.

White-rot fungi are the best option for the complete degradation of whole wood components, including lignin [393]. Compared to fungi, bacteria have been much less investigated, but both types of organisms have demonstrated their potential for lignin depolymerization by different breakdown mechanisms [394]. The biological degradation of lignin by these microorganisms is a complex process that depends on the cellular structure of different wood species [395]. It starts with the action of the extracellular ligninolytic enzymes, which degrade lignin to low molecular weight aromatic compounds. These enzymes can be classified into two different groups according to the reaction mechanism: radical and non-radical ligninolytic enzymes [396]. Radical enzymes are typically secreted first: these enzymes are not selective and depolymerize the lignin molecular structure by oxidative bond cleavage [397]. The enzymatic cocktails secreted for lignin depolymerization by fungi, with Phanerochaete chrysosporium as the most investigated example, contain diverse radical enzymes, globally referred to as lignases [398]. Laccases and peroxidases must be highlighted among lignases [399-401], but alternative lignin-oxidizing enzymes exist, specifically in the case of lignin degradation by bacteria, such as Sphingobacterium sp. [402]. The non-radical ligninolytic enzymes, which are involved in the intracellular metabolic degradation of lignin, are much more selective than radical enzymes. The model lignin structure, rich in $\beta-\mathrm{O}-4$ bonds, can be selectively cleaved by $\beta$-ether enzyme systems. These systems include three complementary enzymes: dehydrogenase, etherase and glutathione-lyase [396]. The first $\beta$-etherases were already reported during the 1980s and Sphingobium sp. has been the most investigated case [403,404]. However, because of their high potential impact for lignin valorization, the search of novel enzymes from alternative organisms and their characterization have been reported [405]. For example, soil isolates, such as Pandoraea norimbergensis, Pseudomonas sp. and Bacillus sp., have been identified as potential lignin depolymerizing bacteria, which provide alternatives outside the fungal kingdom [406].

The production of ligninolytic enzymes by organisms cultivated over biomass wastes can contribute to enhanced sustainable lignocellulosic biomass valorization production, just by improvements in the catalytic and stability properties of these enzymes [407-409].

Once lignin has been enzymatically depolymerized, a huge diversity of different aromatic compounds derived from the three basic phenylpropanoid units appears. Many aromatic-catabolizing organisms are able to use these aromatic compounds as carbon sources. In these upper pathways, a diverse group of enzymes transform the heterogeneous group of aromatic molecules through catabolic funneling to just few central intermediates, such as catechol, protocatechuic acid or gallic acid (Figure 8) [410,411]. The enzymatic cleavage of the C-C bonds in the aromatic rings of these intermediates leads via lower pathways to ring-opened species, which can be incorporated to central carbon metabolism (tricarboxylic acid TCA cycle). 


\section{Aromatic compounds}

(2)<smiles>O=C(O)c1cc(O)c(O)c(O)c1</smiles>

(1)

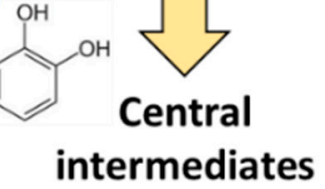<smiles>O=C(O)c1ccc(O)c(O)c1</smiles>
(3) $\mathrm{OH}$
(1) Catechol
(2) Gallic acid
(3) Protocatechuic acid
(4) Oxalacetic acid
(5) Pyruvic acid
(6) Succinic acid
(7) $\beta$-ketoadipic acid

(4)

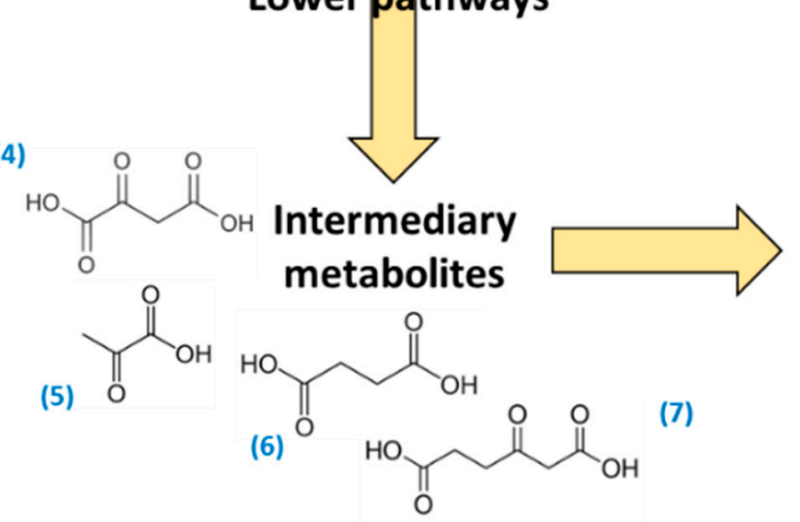

\section{Lower pathways}

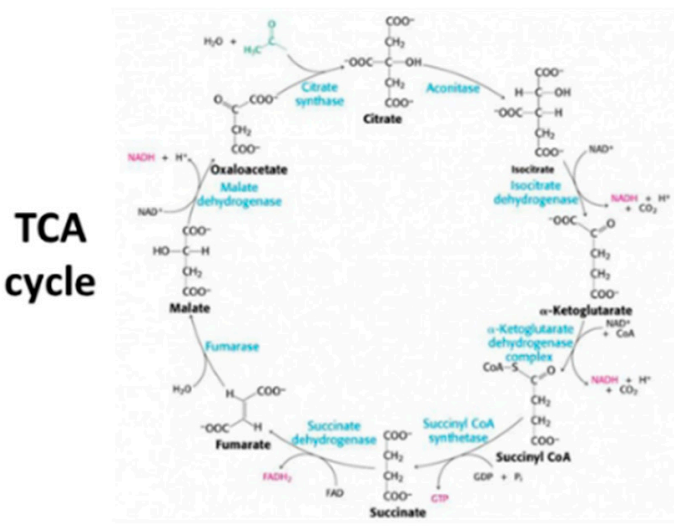

Figure 8. Scheme of catabolic pathway for the degradation of lignin-derived aromatics.

Taking into consideration the valorization of the lignin fraction of lignocellulosic biomass, these biological routes can offer a very useful approach to converging the miscellaneous mixture of the depolymerized lignin fragments into targeted intermediates that can be used to produce valuable chemicals [412]. Therefore, the detailed understanding of the metabolism of the lignin-degrading microorganisms has been an important subject of investigation [413,414]. Moreover, research efforts have been focused on the search for new microorganisms with promising potentiality for lignin degradation and suitable for metabolic engineering [415,416]. Although chemical intervention has been applied to the control of metabolic pathways, such as the use of hydroxamic acids to inhibit certain enzymes involved in the bacterial lignin degradation pathways [417], metabolic engineering appears as a more advantageous approach. Engineered strains of Pseudomonas putida, a well-known effective lignin-degrading bacteria, have shown enhanced production of muconic acid (intermediate in the pathway from catechol to $\beta$-ketoadipic acid) [418], selective production of pyruvic acid instead of succinic acid [419], or reduced accumulation of 4-hydroxybenzoic and vanillic acids (precursors of protocatechuic acid) [420].

Some research groups have tested hybrid processes for lignin valorization that combine chemical and biological stages. For instance, chemical depolymerization, plant metabolic engineering, and synthetic pathway reconstruction were demonstrated for valorizing lignin into value-added products [421]. The researchers reported a direct process for converting alkali lignin into muconic acid and pyrogallol as value-added chemicals. Muconic acid was also the target product of another proposed hybrid process [316]. In this case, lignin liquors obtained by base-catalyzed depolymerization were fed to a bioreactor where muconic acid is produced by engineered P. putida. Biochemical processes based on enzymes are much more easily controllable than biological ones. As an example, highly specific synthesis of aromatic monomers with a phenylpropane structure directly from natural lignin 
using a cascade one-pot reaction using five different enzymes has been proposed [422]. Even simpler enzymatic options have been proposed for the valorization of traditional technical lignin. Kraft lignin or lignosulphonates can be polymerized (or co-polymerized with auxiliary monomers) by laccases to increase their molecular weight and meet application requirements as additives or dispersing agents [423-426].

\subsection{Lignin Applications}

\subsubsection{Lignin-Derived Polymeric Materials}

The potential of lignin without further processing (or with simple processing) for the production of new materials has been deeply investigated [427]. One of the most important applications of lignin in this field is the formulation of new polymers and polyblends (mixtures of two or more polymers). Lignin itself could be considered a thermoplastic [428]. Moreover, since lignin possesses easily-functionalizable hydroxyl and carboxylic acid groups, its compatibility with different polymer types has been extensively examined [429]. Two different approaches have been developed for these purposes. Firstly, lignin can be directly employed as a filler in other polymeric materials to form composites. The second approach involves the incorporation of lignin without or with little chemical transformation in polymer blends or as reactive component of polymer formulations.

Raw lignin can be employed as a reinforcement filler in plastics. Although the mechanical properties of the resulting materials are highly dependent on the polymeric matrix and the filler amount [430], research works have demonstrated significant improvements of the physical properties of the prepared plastics. The incorporation of lignin into the polymeric matrixes (traditional polymers, like polyethylene and polypropylene, or bioplastics, like polylactide, and polyhydroxybutyrate, can be mentioned as examples) results in an enhanced tensile and flexural modulus [431,432]. Lignin as a filler improves the viscoelastic properties of natural and synthetic rubbers and increases the processability of other polymers [433-435]. These modifications induced by lignin as filler in polymers affect their thermal stability or water performance as well $[436,437]$. Furthermore, lignin provides additional characteristics as additive in plastics, since it functions as antioxidant, ultraviolet protection agent or flame retardant [438-440]. Nevertheless, one of the main disadvantages of the use of lignin as filler is the lack of homogeneity among the types of lignin produced from different raw biomass and by different routes. In order to overcome this problem, the simple processing of lignin to obtain nanoparticles with much more uniform characteristics can be proposed as a promising solution to improve the use of lignin as a filler [441].

The addition of lignin to a wide variety of polymeric formulations has been investigated extensively. Polymer blends can either be miscible or immiscible. In most cases, lignin forms immiscible systems with nonpolar polymers, hence multiphasic materials are obtained [442]. Moreover, lignin can replace fossil-derived chemicals in polymer formulations: the replacement of phenol in phenol-formaldehyde resins can be considered the most illustrative case [440,443]. As various reviews cover the complete list of the lignin/polymer systems tested for lignin valorization [444-447], this work only focuses on the most relevant trends identified during the bibliometric analysis.

Firstly, one of the most promising options for lignin valorization is the employment of the multifunctional lignin molecules to replace polyols in the production of polyurethanes [448]. The content of hydroxyl groups and their positions in the aromatic rings determine the lignin reactivity, but great differences appear among the different types of lignin, which have complicated the establishment of lignin as a consolidated monomer [449]. However, improvements in analytical techniques have promoted the progress in lignin characterization and specific functionalization for easier valorization. The combination of lignin and other vegetable molecules, like oleic acid or castor oil, allows the synthesis of controlled architectures with advanced properties that can be tuned by the modification of the polyurethane formulations [450,451]. Secondly, polyesters are a category of polymers easily co-polymerizable with lignin. Several studies have investigated 
the modification of the properties due to the presence of lignin in the structure [452]. Polyester resins with lignin replacing the traditional polyols have been produced and the resulted material exhibited mechanical and thermal resistance properties no lower than the traditional formulations [453]. Moreover, lignin-polyester copolymers with elastomeric properties have been developed. Their tensile, thermal, and thermomechanical properties can be finely controlled by the lignin content and processing conditions [454]. The use of hiperbranched polyester (with amide and amine groups in the structure) allowed the synthesis of advanced materials with thermally stimulated dual shape memory effects, which can be useful in medical applications and consumer products $[455,456]$. Lastly, bio-based plastics have gained much more attention during the last years because more sustainable materials are desired. The incorporation of lignin in these greener formulations has been investigated. Polylactide and polyhydroxybutyrate are among the most recognized bio-based plastics. The addition of lignin resulted in improved performance of these polymers, which shown higher mechanical, thermal and degradation resistance properties [457,458]. Besides, lignin can be copolymerized with other chemicals derived from lignocellulosic biomass, such as cellulose to form cellulose-lignin films with adequate water resistance, antibacterial and oxygen barrier properties; or furfuryl alcohols derived from hemicellulose to form furanic resin foams that can be employed as insulation materials [459].

\subsubsection{Lignin-Derived Carbon Materials}

During the last years, research efforts have been focused on the development of lignin-derived activated carbons, carbon fibers, and other carbonaceous materials [460]. Its high carbon content and molecular structure make lignin a suitable raw material for preparation of activated carbons and detailed studies have covered the preparation, characterization, and applications of these lignin-based adsorbents [461]. Thermal treatments of lignin-rich fractions of lignocellulosic biomass, such as pyrolysis or hydrothermal carbonization, produce carbonaceous materials that must be activated [462]. Two different activation approaches exist to obtain the characteristics desired in activated carbons (highly porous structure with large internal surface area): physical and chemical activation [463,464]. Activated carbons derived from lignin can be employed in liquid and gas phase applications and can be considered as an alternative to traditional activated carbons without economic penalties [9].

Carbon fibers are lightweight and high-strength materials that are useful to produce reinforced composites to be employed in industrial sectors related to transport, like automotive and aerospace applications. Although initially lignin-based carbon fibers did not achieve the mechanical properties of traditional carbon fibers, more recent advances in spinning techniques have improved their performance [465]. Electrospinning and melt-spinning are more advantageous fiber processing techniques, but the structure of the lignin, determined by the biomass nature and isolation process, has great influence over the fiber processing [466-468]. Under optimized conditions, the properties of the carbon fibers derived from lignin can be similar or even higher than the traditional ones, indicating their good potential for more sustainable engineering applications [469].

Regarding other carbonaceous materials, lignin can be converted into carbon-based catalysts or catalyst supports. The chemical functionalization of the carbon material itself [470] or the incorporation of metal precursors and nanoparticles [471] and enzymes [472] result in promising catalysts with several potential applications, including the treatment of lignocellulosic biomass [473].

Once again, the treatment of lignin determines its suitability for catalytic purposes [474]. Besides, more advanced applications have been discovered for lignin-based carbons: their properties make them valuable materials for components in electronic devices. The development of electrodes with outstanding performance just by simple fabrication processes is very promising for future energy-storage systems and sensors [475-478].

\subsubsection{Lignin-Derived Aromatic Compounds}

Because of its intrinsic structure, lignin must be considered the most suitable renewable source of aromatic compounds. Despite the challenging processing of lignin (biomass pretreatment, lignin 
separation or isolation, depolymerization and upgrading), the production of high-volume aromatic intermediates and low-volume end products from lignin are the most sustainable solutions to avoid the consumption of fossil resources in making these chemicals available. The identification of the most interesting value-added chemicals that can be derived from lignin was performed a decade ago by researchers from the Pacific Northwest National Laboratory and the National Renewable Energy Laboratory [31].

On the one hand, the aggressive depolymerization of lignin by means of non-selective cleavage of $\mathrm{C}-\mathrm{C}$ and $\mathrm{C}-\mathrm{O}$ bonds results in BTXs (benzene, toluene and xylenes) and phenol, with some light $\left(\mathrm{C}_{1}\right.$ to $\mathrm{C}_{3}$ ) aliphatic and $\mathrm{C}_{6}-\mathrm{C}_{7}$ cycloaliphatic compounds. These products can be directly used by established conventional petrochemical processes [479]. On the other hand, the selective depolymerization of lignin can produce a wide variety of complex aromatics, some of them quite difficult to be produce by traditional petrochemical routes. Among these chemicals, which retain the structure of the original monomeric phenylpropanoid units, some examples must be mentioned (Figure 9). Guaiacol is used as an intermediate in the production of flavors, fragrances, and pharmaceuticals. For instance, synthetic vanillin, which accounts for about $85 \%$ of the global vanillin supply, has been traditionally produced from petrochemical guaiacol. Syringol is the main aroma principle of smoked and grilled foods and is used in synthetic smoke flavorings. Catechol is another important intermediate in chemical industries, as it is a building block in the production of a wide spectrum of products such as insecticides, perfumes, and pharmaceuticals [480]. Oxidized lignin monomers are also valuable chemicals. Vanillin is the most interesting product, since it is the world's most used flavoring agent. Vanillin-derived chemicals, like vanillic acid, are applied as flavoring agents as well. Besides vanillin, syringaldehyde and various aromatic aldehydes must be mentioned as relevant oxidized monomers [481].<smiles>COc1ccccc1O</smiles>

Guaiacol<smiles>COc1cc(C=O)ccc1O</smiles>

Vanillin<smiles>COc1cccc(OC)c1O</smiles>

Syringol<smiles>COc1cc(C(=O)O)ccc1O</smiles>

Vanillinic acid<smiles>Oc1ccccc1O</smiles>

Catechol<smiles>COc1cc(C=O)cc(OC)c1O</smiles>

Syringaldehyde

Figure 9. Aromatic chemicals that retain the original lignin monomeric structure.

\section{Conclusions}

This work completes a bibliometric overview of the research on the valorization of lignin during the 2000-2016 period. Although this topic is investigated using a relevant interdisciplinary approach, Chemical Engineering is the leading category, followed by Environmental Sciences, and Chemistry. The USA was the most productive country with the largest number of documents (19\%) followed by four European countries (Spain, France, Netherlands, and Portugal) from the second to the fifth position respectively, while the sixth position occupied by China.

Research covers the determination of the lignin structure, isolation, and characterization, depolymerization by thermal and thermochemical methods, chemical, biochemical, and biological 
conversion of depolymerized lignin and lignin applications. When focusing on the isolation of lignin, the different methods available can be classified into two main categories: the ones that are based on the hydrolysis of cellulose and hemicelluloses to maintain lignin as an insoluble solid, and the ones that dissolve lignin while cellulose and hemicellulose remain in the insoluble residue. These are the preferred methods to produce technical lignins.

Regarding lignin depolymerization, most methods are focused on the selective cleavage of the $\beta-\mathrm{O}-4$ linkage, however the quality, molecular weight distribution, solubility, reactivity, and structure of the isolated lignin differ strongly depending on the raw material and the depolymerization method used. Because of that, different target end products should be taken into account to select the optimal depolymerization option. Relating to the chemical depolymerization of lignin many options have been reported: solvolysis with sub-critical and super-critical water, organic solvents like alcohols with and without catalyst, ionic-liquids and deep eutectic solvents; reductive depolymerization with hydrogen; oxidative depolymerization with potassium permanganate, nitrobenzene, hydrogen peroxide; oxygen; or acid or alkali catalytic depolymerization, among others. However, depolymerization with sodium hydroxide is the dominant process in the industrial scale because is a cheap solution that offers a high depolymerization activity due to its strong strength and because the solvent can be recuperated, regenerated, or recycled.

Concerning chemical conversion on lignin, the wide variety of phenolic monomers and oligomers obtained after lignin depolymerization limits their direct applications and reductive treatment were proposed to remove the chemically bonded oxygen. But as the hydrogenation of the aromatic rings is thermodynamically favored instead of the hydrogenolysis of C-O bonds, the design of new functional catalysts with high selectivity is crucial to overcome this situation. Compared to reductive conversion, oxidation transforms lignin to more complicated chemical with extensive functionality, mainly low molecular weight phenolic compounds, some of which have direct application as end products or as platform chemicals. However, because of the variety of structures formed during this process, fractionation and purification are needed and these processes could be expensive. As the phenolic groups are the most reactive functional groups and determine the chemical reactivity of the depolymerized lignin, modification on these groups can lead to the formation of valuable chemicals. Esterification is one of the most practical functionalization reactions since lignin-based polyesters can be employed for polymer production.

Biological and biochemical processes are promising for lignin valorization since they can overcome the high heterogeneity of lignin better than traditional chemical strategies. Manly fungi have been investigated for the degradation of lignin although bacteria also show potential for lignin depolymerization by different breakdown mechanisms. Research efforts have been focused on the development of new microorganisms with promising potentiality for lignin degradation that are suitable for metabolic engineering.

Lignin applications can be divided according to the lignin structure into: lignin-derived aromatic compounds, lignin-derived carbon materials, and lignin-derived polymeric materials. Because of its structure lignin must be considered the most suitable renewable source of aromatic compounds and the production of high-volume aromatic intermediates and low-volume end products from lignin has been proposed as the most sustainable solution to avoid the consumption of fossil resources to make these chemicals available. Vanillin is the most interesting oxidized lignin monomer since it is the world's most used flavoring agent; however, other monomers should also be considered like guaiacol, syringol, vanillic acid, syringaldehyde, and others aromatic aldehydes.

Due to its high carbon content, lignin is also suitable for the preparation of activated carbons, carbon fibers, and other carbonaceous materials. Thermal treatments of lignin produce carbonaceous materials that can be physically or chemically activated and can be considered as an alternative to traditional activated carbons without economic penalties. Carbon fibers are a lightweight and high-strength material useful to produce reinforced composites to be employed in many sectors such as the automotive and aerospace industries. The properties on the carbon fibers from lignin can be 
similar or even higher than the traditional ones. Regarding other carbonaceous materials, lignin can be converted into carbon-based catalysts or catalyst supports. Finally, the potential of lignin without or with minimal processing for the production of new material has been deeply investigated, and the formulation of new polymers and polyblends is the most important application of lignin. Lignin can be used directly as a filler in other polymeric materials or can be a reactive component of polymer formulations. The replacement of phenol in phenol-formaldehyde resin is the application that it is already in an industrial scale, but the replacement of polyols in the production of polyurethanes appears as one of the most promising options for lignin valorization.

Nonetheless, the diverse potential valorization options for lignocellulosic biomass must be evaluated and compared from a sustainability point of view to identify the most sustainable biorefining routes, taking into consideration the economic, environmental, and social aspects. Moreover, even after this holistic consideration, the identified proposals cannot be considered a universal solution to be directly extrapolated from one case to another. The specificities related to the geographic distribution of different raw biomasses, the required products and applications or the available markets are going to define individualized optimal solutions for each considered scenario.

Author Contributions: R.A. conceived the idea, collected literature, and prepared the first version of the manuscript. H.P.-A. performed the bibliographic analysis of the literature and included it in the manuscript. L.C. completed, revised, and edited the manuscript. All authors read, revised, and approved the final manuscript.

Funding: This research has been financially supported by the Spanish Ministry of Economy and Competitiveness (MINECO) through CTQ2014-56820-JIN Project, co-financed by FEDER funds from European Union. R. Abejón would also like to thank the financial support provided by “Becas Iberoamérica Santander Investigación 2016/2017 (Santander Universidades)".

Conflicts of Interest: The authors declare no conflict of interest.

\section{References}

1. Pedras, B.; Salema-Oom, M.; Sá-Nogueira, I.; Simões, P.; Paiva, A.; Barreiros, S. Valorization of white wine grape pomace through application of subcritical water: Analysis of extraction, hydrolysis, and biological activity of the extracts obtained. J. Supercrit. Fluids 2017, 128, 138-144. [CrossRef]

2. Azadi, P.; Inderwildi, O.R.; Farnood, R.; King, D.A. Liquid fuels, hydrogen and chemicals from lignin: A critical review. Renew. Sustain. Energy Rev. 2013, 21, 506-523. [CrossRef]

3. Loow, Y.-L.; New, E.K.; Yang, G.H.; Ang, L.Y.; Foo, L.Y.W.; Wu, T.Y. Potential use of deep eutectic solvents to facilitate lignocellulosic biomass utilization and conversion. Cellulose 2017, 24, 3591-3618. [CrossRef]

4. Sadhukhan, J.; Martinez-Hernandez, E.; Murphy, R.J.; Ng, D.K.S.; Hassim, M.H.; Siew Ng, K.; Yoke Kin, W.; Jaye, I.F.M.; Leung Pah Hang, M.Y.; Andiappan, V. Role of bioenergy, biorefinery and bioeconomy in sustainable development: Strategic pathways for Malaysia. Renew. Sustain. Energy Rev. 2018, 81, 1966-1987. [CrossRef]

5. Aditiya, H.B.; Mahlia, T.M.I.; Chong, W.T.; Nur, H.; Sebayang, A.H. Second generation bioethanol production: A critical review. Renew. Sustain. Energy Rev. 2016, 66, 631-653. [CrossRef]

6. Naidu, D.S.; Hlangothi, S.P.; John, M.J. Bio-based products from xylan: A review. Carbohydr. Polym. 2018, 179, 28-41. [CrossRef] [PubMed]

7. Avanthi, A.; Kumar, S.; Sherpa, K.C.; Banerjee, R. Bioconversion of hemicelluloses of lignocellulosic biomass to ethanol: An attempt to utilize pentose sugars. Biofuels 2017, 8, 431-444. [CrossRef]

8. Li, C.; Zhao, X.; Wang, A.; Huber, G.W.; Zhang, T. Catalytic Transformation of Lignin for the Production of Chemicals and Fuels. Chem. Rev. 2015, 115, 11559-11624. [CrossRef] [PubMed]

9. Cline, S.P.; Smith, P.M. Opportunities for lignin valorization: An exploratory process. Energy Sustain. Soc. 2017, 7. [CrossRef]

10. Xiao, L.P.; Wang, S.; Li, H.; Li, Z.; Shi, Z.J.; Xiao, L.; Sun, R.C.; Fang, Y.; Song, G. Catalytic Hydrogenolysis of Lignins into Phenolic Compounds over Carbon Nanotube Supported Molybdenum Oxide. ACS Catal. 2017, 7, 7535-7542. [CrossRef]

11. Davis, K.M.; Rover, M.; Brown, R.C.; Bai, X.; Wen, Z.; Jarboe, L.R. Recovery and utilization of lignin monomers as part of the biorefinery approach. Energies 2016, 9. [CrossRef] 
12. Ilina, L.Y.; Zibareva, I.V.; Vedyagin, A.A. Scientific legacy of Georgy K. Boreskov: Bibliometric and thematic analysis. React. Kinet. Mech. Catal. 2017, 122, 685-697. [CrossRef]

13. Kikuchi, Y. Simulation-based approaches for design of smart energy system: A review applying bibliometric analysis. J. Chem. Eng. Jpn. 2017, 50, 385-396. [CrossRef]

14. Tian, X.; Geng, Y.; Zhong, S.; Wilson, J.; Gao, C.; Chen, W.; Yu, Z.; Hao, H. A bibliometric analysis on trends and characters of carbon emissions from transport sector. Transp. Res. Part D Transp. Environ. 2018, 59, 1-10. [CrossRef]

15. Zhang, M.; Gao, Z.; Zheng, T.; Ma, Y.; Wang, Q.; Gao, M.; Sun, X. A bibliometric analysis of biodiesel research during 1991-2015. J. Mater. Cycles Waste Manag. 2018, 20, 10-18. [CrossRef]

16. Olawumi, T.O.; Chan, D.W.M.; Wong, J.K.W. Evolution in the intellectual structure of BIM research: A bibliometric analysis. J. Civ. Eng. Manag. 2017, 23, 1060-1081. [CrossRef]

17. Li, W.; Dong, H.; Yu, H.; Wang, D.; Yu, H. Global characteristics and trends of research on ceramic membranes from 1998 to 2016: Based on bibliometric analysis combined with information visualization analysis. Ceram. Int. 2018, 1-9. [CrossRef]

18. Ren, Y.; Yu, M.; Wu, C.; Wang, Q.; Gao, M.; Huang, Q.; Liu, Y. A comprehensive review on food waste anaerobic digestion: Research updates and tendencies. Bioresour. Technol. 2018, 247, 1069-1076. [CrossRef] [PubMed]

19. Pérez-Acebo, H.; Linares-Unamunzaga, A.; Abejón, R.; Rojí, E. Research Trends in Pavement Management during the First Years of the 21st Century: A Bibliometric Analysis during the 2000-2013 Period. Appl. Sci. 2018, 8. [CrossRef]

20. Scopus. Scopus: Content Coverage Guide (02.16 Version); Elsevier: Amsterdam, The Netherlands, 2016.

21. Mesdaghinia, A.; Mahvi, A.H.; Nasseri, S.; Nodehi, R.N.; Hadi, M. A bibliometric analysis on the solid waste-related research from 1982 to 2013 in Iran. Int. J. Recycl. Org. Waste Agric. 2015, 4, 185-195. [CrossRef]

22. Abejón, R. A Bibliometric Study of Scientific Publications regarding Hemicellulose Valorization during the 2000-2016 Period: Identification of Alternatives and Hot Topics. ChemEngineering 2018, 2. [CrossRef]

23. Wambu, E.W.; Ho, Y.-S. A bibliometric analysis of drinking water research in Africa. Water SA $2016,42$. [CrossRef]

24. Abejón, R.; Garea, A. A bibliometric analysis of research on arsenic in drinking water during the 1992-2012 period: An outlook to treatment alternatives for arsenic removal. J. Water Process Eng. 2015, 6, 105-119. [CrossRef]

25. Abejón, R.; Pérez-Acebo, H.; Garea, A. A Bibliometric Analysis of Research on Supported Ionic Liquid Membranes during the 1995-2015 Period: Study of the Main Applications and Trending Topics. Membranes 2017, 7. [CrossRef] [PubMed]

26. Mao, G.; Liu, X.; Du, H.; Zuo, J.; Wang, L. Way forward for alternative energy research: A bibliometric analysis during 1994-2013. Renew. Sustain. Energy Rev. 2015, 48, 276-286. [CrossRef]

27. Tardy, C. The role of English in scientific communication: Lingua franca or Tyrannosaurus rex? J. Engl. Acad. Purp. 2004, 3, 247-269. [CrossRef]

28. Li, N.; Han, R.; Lu, X. Bibliometric analysis of research trends on solid waste reuse and recycling during 1992-2016. Resour. Conserv. Recycl. 2018, 130, 109-117. [CrossRef]

29. Makhoba, X.; Pouris, A. Bibliometric analysis of the development of nanoscience research in South Africa. S. Afr. J. Sci. 2017, 113, 1-9. [CrossRef]

30. Werpy, T.; Petersen, G. Top Value Added Chemicals from Biomass Volume I-Results of Screening for Potential Candidates from Sugars and Synthesis Gas Top Value Added Chemicals from Biomass Volume I: Results of Screening for Potential Candidates; DOE Scientific and Technical Information, US Department of Energy: Washington, DC, USA, 2004; ISBN DOE/GO-102004-1992.

31. Holladay, J.E.; White, J.F.; Bozell, J.J.; Johnson, D. Top Value-Added Chemicals from Biomass Volume II-Results of Screening for Potential Candidates from Biorefinery Lignin; DOE Scientific and Technical Information, US Department of Energy: Washington, DC, USA, 2007; ISBN PNNL-16983.

32. Tuck, C.O.; Perez, E.; Horvath, I.T.; Sheldon, R.A.; Poliakoff, M. Valorization of Biomass: Deriving More Value from Waste. Science 2012, 337, 695-699. [CrossRef] [PubMed]

33. Lange, J.P. Lignocellulose conversion: An introduction to chemistry, process and economics. Biofuels Bioprod. Biorefin. 2007, 1, 39-48. [CrossRef] 
34. Zakzeski, J.; Bruijnincx, P.C.A.; Jongerius, A.L.; Weckhuysen, B.M. The Catalytic Valorization of Ligning for the Production of Renewable Chemicals. Chem. Rev. 2010, 110, 3552-3599. [CrossRef] [PubMed]

35. Ragauskas, A.J.; Beckham, G.T.; Biddy, M.J.; Chandra, R.; Chen, F.; Davis, M.F.; Davison, B.H.; Dixon, R.A.; Gilna, P.; Keller, M.; et al. Lignin valorization: Improving lignin processing in the biorefinery. Science 2014, 344. [CrossRef] [PubMed]

36. Gnansounou, E.; Dauriat, A. Technoeconomic analysis of lignocellulosic ethanol. Biofuels 2011, 101, $123-148$. [CrossRef]

37. Tadesse, H.; Luque, R. Advances on biomass pretreatment using ionic liquids: An overview. Energy Environ. Sci. 2011, 4. [CrossRef]

38. Rahimi, A.; Ulbrich, A.; Coon, J.J.; Stahl, S.S. Formic-acid-induced depolymerization of oxidized lignin to aromatics. Nature 2014, 515, 249-252. [CrossRef] [PubMed]

39. Song, Q.; Wang, F.; Cai, J.; Wang, Y.; Zhang, J.; Yu, W.; Xu, J. Lignin depolymerization (LDP) in alcohol over nickel-based catalysts via a fragmentation-hydrogenolysis process. Energy Environ. Sci. 2010, 6, 994-1007. [CrossRef]

40. Wang, J.; Zheng, T.; Wang, Q.; Wang, C.; Wang, L. Global Trends of Electrodialysis Research during 1991-2014: A Bibliometric Analysis. J. Chem. Soc. Pak. 2016, 38, 775-788.

41. Schutyser, W.; Renders, T.; Van den Bosch, S.; Koelewijn, S.-F.; Beckham, G.T.; Sels, B.F. Chemicals from lignin: An interplay of lignocellulose fractionation, depolymerisation, and upgrading. Chem. Soc. Rev. 2018, 47, 852-908. [CrossRef] [PubMed]

42. Xu, L.; Zhang, Y.; Fu, Y. Advances in Upgrading Lignin Pyrolysis Vapors by Ex Situ Catalytic Fast Pyrolysis. Energy Technol. 2017, 5, 30-51. [CrossRef]

43. Cheng, F.; Brewer, C.E. Producing jet fuel from biomass lignin: Potential pathways to alkyl-benzenes and cycloalkanes. Renew. Sustain. Energy Rev. 2017, 72, 673-722. [CrossRef]

44. Rutten, C.; Ramírez, A.; Posada Duque, J. Hydrotreating and hydrothermal treatment of alkaline lignin as technological valorization options for future biorefinery concepts: A review. J. Chem. Technol. Biotechnol. 2017, 92, 257-270. [CrossRef]

45. Kamimura, N.; Takahashi, K.; Mori, K.; Araki, T.; Fujita, M.; Higuchi, Y.; Masai, E. Bacterial catabolism of lignin-derived aromatics: New findings in a recent decade: Update on bacterial lignin catabolism. Environ. Microbiol. Rep. 2017, 9, 679-705. [CrossRef] [PubMed]

46. Key, R.E.; Bozell, J.J. Progress toward Lignin Valorization via Selective Catalytic Technologies and the Tailoring of Biosynthetic Pathways. ACS Sustain. Chem. Eng. 2016, 4, 5123-5135. [CrossRef]

47. Palazzolo, M.A.; Kurina-Sanz, M. Microbial utilization of lignin: Available biotechnologies for its degradation and valorization. World J. Microbiol. Biotechnol. 2016, 32. [CrossRef] [PubMed]

48. Xie, S.; Ragauskas, A.J.; Yuan, J.S. Lignin Conversion: Opportunities and Challenges for the Integrated Biorefinery. Ind. Biotechnol. 2016, 12, 161-167. [CrossRef]

49. Narron, R.H.; Kim, H.; Chang, H.M.; Jameel, H.; Park, S. Biomass pretreatments capable of enabling lignin valorization in a biorefinery process. Curr. Opin. Biotechnol. 2016, 38, 39-46. [CrossRef] [PubMed]

50. Rinaldi, R.; Jastrzebski, R.; Clough, M.T.; Ralph, J.; Kennema, M.; Bruijnincx, P.C.A.; Weckhuysen, B.M. Paving the Way for Lignin Valorisation: Recent Advances in Bioengineering, Biorefining and Catalysis. Angew. Chem. Int. Ed. 2016, 55, 8164-8215. [CrossRef] [PubMed]

51. De, S.; Dutta, S.; Saha, B. Critical design of heterogeneous catalysts for biomass valorization: Current thrust and emerging prospects. Catal. Sci. Technol. 2016, 6, 7364-7385. [CrossRef]

52. Liu, W.-J.; Jiang, H.; Yu, H.-Q. Thermochemical conversion of lignin to functional materials: A review and future directions. Green Chem. 2015, 17, 4888-4907. [CrossRef]

53. Pollegioni, L.; Tonin, F.; Rosini, E. Lignin-degrading enzymes. FEBS J. 2015, 282, 1190-1213. [CrossRef] [PubMed]

54. Chatel, G.; Rogers, R.D. Review: Oxidation of lignin using ionic liquids-an innovative strategy to produce renewable chemicals. ACS Sustain. Chem. Eng. 2014, 2, 322-339. [CrossRef]

55. Asgher, M.; Shahid, M.; Kamal, S.; Iqbal, H.M.N. Recent trends and valorization of immobilization strategies and ligninolytic enzymes by industrial biotechnology. J. Mol. Catal. B Enzym. 2014, 101, 56-66. [CrossRef]

56. Deuss, P.J.; Barta, K.; de Vries, J.G. Homogeneous catalysis for the conversion of biomass and biomass-derived platform chemicals. Catal. Sci. Technol. 2014, 4, 1174-1196. [CrossRef] 
57. Laskar, D.D.; Yang, B.; Wang, H.; Lee, J. Pathways for biomass-derived lignin to hydrocarbon fuels. Biofuels Bioprod. Biorefin. 2013, 7, 602-626. [CrossRef]

58. Chen, Z.; Wan, C. Biological valorization strategies for converting lignin into fuels and chemicals. Renew. Sustain. Energy Rev. 2017, 73, 610-621. [CrossRef]

59. Chávez-Sifontes, M.; Domine, M.E. Lignina, estructura y aplicaciones: Métodos de despolimerización para la obtención de derivados aromáticos de interés industrial. Aav. Cienc. Ing. 2013, 4, 15-46.

60. Joffres, B.; Laurenti, D.; Charon, N.; Daudin, A.; Quignard, A.; Geantet, C. Thermochemical Conversion of Lignin for Fuels and Chemicals: A Review. Oil Gas Sci. Technol. Rev. IFP Energies Nouv. 2013, 68, 753-763. [CrossRef]

61. Araya, F.; Troncoso, E.; Mendonça, R.T.; Freer, J. Condensed lignin structures and re-localization achieved at high severities in autohydrolysis of Eucalyptus globulus wood and their relationship with cellulose accessibility. Biotechnol. Bioeng. 2015, 112, 1783-1791. [CrossRef] [PubMed]

62. Zeng, Y.; Zhao, S.; Yang, S.; Ding, S.Y. Lignin plays a negative role in the biochemical process for producing lignocellulosic biofuels. Curr. Opin. Biotechnol. 2014, 27, 38-45. [CrossRef] [PubMed]

63. Hatfield, R.; Fukushima, R.S. Can lignin be accurately measured? Crop Sci. 2005, 45, 832-839. [CrossRef]

64. Nicholson, D.J.; Leavitt, A.T.; Francis, R.C. A three-stage klason method for more accurate determinations of hardwood lignin content. Cellul. Chem. Technol. 2014, 48, 53-59.

65. Hu, Z.; Yeh, T.F.; Chang, H.M.; Matsumoto, Y.; Kadla, J.F. Elucidation of the structure of cellulolytic enzyme lignin. Holzforschung 2006, 60, 389-397. [CrossRef]

66. Wang, K.; Bauer, S.; Sun, R.C. Structural transformation of miscanthus $\times$ giganteus lignin fractionated under mild formosolv, basic organosolv, and cellulolytic enzyme conditions. J. Agric. Food Chem. 2012, 60, 144-152. [CrossRef] [PubMed]

67. Capanema, E.; Balakshin, M.; Katahira, R.; Chang, H.M.; Jameel, H. How well do MWL and CEL preparations represent the whole hardwood lignin? J. Wood Chem. Technol. 2014, 35, 17-26. [CrossRef]

68. Jiang, Y.; Li, Z.; Tang, X.; Sun, Y.; Zeng, X.; Liu, S.; Lin, L. Depolymerization of cellulolytic enzyme lignin for the production of monomeric phenols over Raney Ni and acidic zeolite catalysts. Energy Fuels 2015, 29, 1662-1668. [CrossRef]

69. Tian, D.; Hu, J.; Chandra, R.P.; Saddler, J.N.; Lu, C. Valorizing Recalcitrant Cellulolytic Enzyme Lignin via Lignin Nanoparticles Fabrication in an Integrated Biorefinery. ACS Sustain. Chem. Eng. 2017, 5, 2702-2710. [CrossRef]

70. Ma, Z.; Tang, J.; Li, S.; Suo, E. Reactivity improvement of cellulolytic enzyme lignin via mild hydrothermal modification. Bioorg. Chem. 2017, 75, 173-180. [CrossRef] [PubMed]

71. Wu, S.; Argyropoulos, D.S. An improved method for isolating lignin in high yield and purity. J. Pulp Pap. Sci. 2003, 29, 235-240.

72. Guerra, A.; Lucia, L.A.; Argyropoulos, D.S. Isolation and characterization of lignins from Eucalyptus grandis Hill ex Maiden and Eucalyptus globulus Labill. By enzymatic mild acidolysis (EMAL). Holzforschung 2008, 62, 24-30. [CrossRef]

73. Zoia, L.; Orlandi, M.; Argyropoulos, D.S. Microwave-assisted lignin isolation using the enzymatic mild acidolysis (EMAL) protocol. J. Agric. Food Chem. 2008, 56, 10115-10122. [CrossRef] [PubMed]

74. Lou, R.; Wu, S.B.; Lv, G.J.; Guo, D.L. Pyrolytic products from rice straw and enzymatic/mild acidolysis lignin (EMAL). BioResources 2010, 5, 2184-2194. [CrossRef]

75. Lou, R.; Wu, S. bin Products properties from fast pyrolysis of enzymatic/mild acidolysis lignin. Appl. Energy 2011, 88, 316-322. [CrossRef]

76. Cheng, H.; Wu, S.; Li, X. Comparison of the oxidative pyrolysis behaviors of black liquor solids, alkali lignin and enzymatic hydrolysis/mild acidolysis lignin. RSC Adv. 2015, 5, 79532-79537. [CrossRef]

77. Cheng, H.; Wu, S. Effect of Copper Oxide on Fast Pyrolysis of Enzymatic/mild Acidolysis Lignin. Energy Procedia 2017, 105, 1015-1021. [CrossRef]

78. Björkman, A. Isolation of lignin from finely divided wood with neutral solvents. Nature 1954, 174, 1057-1058. [CrossRef]

79. Brauns, F.E. Native Lignin I. Its Isolation and Methylation. J. Am. Chem. Soc. 1939, 61, 2120-2127. [CrossRef]

80. Hiltunen, E.; Alvila, L.; Pakkanen, T.T. Characterization of Brauns' lignin from fresh and vacuum-dried birch (Betula pendula) wood. Wood Sci. Technol. 2006, 40, 575-584. [CrossRef] 
81. Holtman, K.M.; Chang, H.M.; Jameel, H.; Kadla, J.F. Quantitative13C NMR characterization of milled wood lignins isolated by different milling techniques. J. Wood Chem. Technol. 2006, 26, 21-34. [CrossRef]

82. Wang, S.; Wang, K.; Liu, Q.; Gu, Y.; Luo, Z.; Cen, K.; Fransson, T. Comparison of the pyrolysis behavior of lignins from different tree species. Biotechnol. Adv. 2009, 27, 562-567. [CrossRef] [PubMed]

83. Crestini, C.; Melone, F.; Sette, M.; Saladino, R. Milled wood lignin: A linear oligomer. Biomacromolecules 2011, 12, 3928-3935. [CrossRef] [PubMed]

84. Agarwal, U.P.; McSweeny, J.D.; Ralph, S.A. FT-raman investigation of milled-wood lignins: Softwood, hardwood, and chemically modified black spruce lignins. J. Wood Chem. Technol. 2011, 31, 324-344. [CrossRef]

85. Galkin, M.V.; Samec, J.S.M. Lignin Valorization through Catalytic Lignocellulose Fractionation: A Fundamental Platform for the Future Biorefinery. ChemSusChem 2016, 9, 1544-1558. [CrossRef] [PubMed]

86. Moshkelani, M.; Marinova, M.; Perrier, M.; Paris, J. The forest biorefinery and its implementation in the pulp and paper industry: Energy overview. Appl. Therm. Eng. 2013, 50, 1427-1436. [CrossRef]

87. Rafione, T.; Marinova, M.; Montastruc, L.; Paris, J. The Green Integrated Forest Biorefinery: An innovative concept for the pulp and paper mills. Appl. Therm. Eng. 2014, 73, 72-79. [CrossRef]

88. Aleš, H.; Michal, J.; Lenka, D.; Alexandra, S.; Igor, Š. Thermal Properties and Size Distribution of Lignins Precipitated with Sulphuric Acid. Wood Res. 2015, 60, 375-384.

89. Lancefield, C.S.; Rashid, G.M.M.; Bouxin, F.; Wasak, A.; Tu, W.C.; Hallett, J.; Zein, S.; Rodríguez, J.; Jackson, S.D.; Westwood, N.J.; et al. Investigation of the Chemocatalytic and Biocatalytic Valorization of a Range of Different Lignin Preparations: The Importance of $\beta-\mathrm{O}-4$ Content. ACS Sustain. Chem. Eng. 2016, 4, 6921-6930. [CrossRef]

90. Santos, J.I.; Fillat, Ú.; Martín-Sampedro, R.; Eugenio, M.E.; Negro, M.J.; Ballesteros, I.; Rodríguez, A.; Ibarra, D. Evaluation of lignins from side-streams generated in an olive tree pruning-based biorefinery: Bioethanol production and alkaline pulping. Int. J. Biol. Macromol. 2017, 105, 238-251. [CrossRef] [PubMed]

91. Karp, E.M.; Resch, M.G.; Donohoe, B.S.; Ciesielski, P.N.; O’Brien, M.H.; Nill, J.E.; Mittal, A.; Biddy, M.J.; Beckham, G.T. Alkaline Pretreatment of Switchgrass. ACS Sustain. Chem. Eng. 2015, 3, 1479-1491. [CrossRef]

92. Argun, H.; Onaran, G. Delignification of vineyard pruning residues by alkaline peroxide treatment. Ind. Crops Prod. 2015, 74, 697-702. [CrossRef]

93. Romaní, A.; Ruiz, H.A.; Teixeira, J.A.; Domingues, L. Valorization of Eucalyptus wood by glycerol-organosolv pretreatment within the biorefinery concept: An integrated and intensified approach. Renew. Energy 2016, 95, 1-9. [CrossRef]

94. Mittal, A.; Katahira, R.; Donohoe, B.S.; Black, B.A.; Pattathil, S.; Stringer, J.M.; Beckham, G.T. Alkaline Peroxide Delignification of Corn Stover. ACS Sustain. Chem. Eng. 2017, 5, 6310-6321. [CrossRef]

95. Zoia, L.; Salanti, A.; Tolppa, E.L.; Ballabio, D.; Orlandi, M. Valorization of Side-Streams from a SSF Biorefinery Plant: Wheat Straw Lignin Purification Study. BioResources 2017, 12, 1680-1696. [CrossRef]

96. Vishtal, A.; Kraslawski, A. Challenges in industrial applications of technical lignins. BioResources 2011, 6, 3547-3568.

97. Zhao, X.; Li, S.; Wu, R.; Liu, D. Organosolv fractionating pre-treatment of lignocellulosic biomass for effi cient enzymatic saccharifi cation: Chemistry, kinetics, and substrate structures. Biofuels Bioprod. Biorefin. 2017, 11, 567-590. [CrossRef]

98. Erdocia, X.; Prado, R.; Corcuera, M.Á.; Labidi, J. Effect of different organosolv treatments on the structure and properties of olive tree pruning lignin. J. Ind. Eng. Chem. 2014, 20, 1103-1108. [CrossRef]

99. Capolupo, L.; Faraco, V. Green methods of lignocellulose pretreatment for biorefinery development. Appl. Microbiol. Biotechnol. 2016, 100, 9451-9467. [CrossRef] [PubMed]

100. Li, M.F.; Yang, S.; Sun, R.C. Recent advances in alcohol and organic acid fractionation of lignocellulosic biomass. Bioresour. Technol. 2016, 200, 971-980. [CrossRef] [PubMed]

101. Zhang, Z.; Harrison, M.D.; Rackemann, D.W.; Doherty, W.O.S.; O’Hara, I.M. Organosolv pretreatment of plant biomass for enhanced enzymatic saccharification. Green Chem. 2016, 18, 360-381. [CrossRef]

102. Alfaro, A.; Rivera, A.; Pérez, A.; Yáñez, R.; García, J.C.; López, F. Integral valorization of two legumes by autohydrolysis and organosolv delignification. Bioresour. Technol. 2009, 100, 440-445. [CrossRef] [PubMed]

103. Alfaro, A.; López, F.; Pérez, A.; García, J.C.; Rodríguez, A. Integral valorization of tagasaste (Chamaecytisus proliferus) under hydrothermal and pulp processing. Bioresour. Technol. 2010, 101, 7635-7640. [CrossRef] [PubMed] 
104. Constant, S.; Barakat, A.; Robitzer, M.; Di Renzo, F.; Dumas, C.; Quignard, F. Composition, texture and methane potential of cellulosic residues from Lewis acids organosolv pulping of wheat straw. Bioresour. Technol. 2016, 216, 737-743. [CrossRef] [PubMed]

105. Fernández-Rodríguez, J.; Robles, E.; Gordobil, O.; González-Alriols, M.; Labidi, J. Lignin valorisation from side-streams produced during agriculture waste pulping and TCF bleaching. Chem. Eng. Trans. 2016, 52, 187-192. [CrossRef]

106. Fernández-Rodríguez, J.; Gordobil, O.; Robles, E.; González-Alriols, M.; Labidi, J. Lignin valorization from side-streams produced during agricultural waste pulping and total chlorine free bleaching. J. Clean. Prod. 2017, 142, 2609-2617. [CrossRef]

107. Gandolfi, S.; Pistone, L.; Ottolina, G.; Xu, P.; Riva, S. Hemp hurds biorefining: A path to green l-(+)-lactic acid production. Bioresour. Technol. 2015, 191, 59-65. [CrossRef] [PubMed]

108. Schwiderski, M.; Kruse, A. Process design and economics of an aluminium chloride catalysed organosolv process. Biomass Convers. Biorefin. 2016, 6, 335-345. [CrossRef]

109. Salapa, I.; Katsimpouras, C.; Topakas, E.; Sidiras, D. Organosolv pretreatment of wheat straw for efficient ethanol production using various solvents. Biomass Bioenergy 2017, 100, 10-16. [CrossRef]

110. Wang, B.; Shen, X.J.; Wen, J.L.; Xiao, L.; Sun, R.C. Evaluation of organosolv pretreatment on the structural characteristics of lignin polymers and follow-up enzymatic hydrolysis of the substrates from Eucalyptus wood. Int. J. Biol. Macromol. 2017, 97, 447-459. [CrossRef] [PubMed]

111. Wu, M.; Pang, J.; Zhang, X.; Sun, R. Enhancement of lignin biopolymer isolation from hybrid poplar by organosolv pretreatments. Int. J. Polym. Sci. 2014. [CrossRef]

112. Wang, K.; Yang, H.; Guo, S.; Tang, Y.; Jiang, J.; Xu, F.; Sun, R.C. Organosolv fractionation process with various catalysts for improving bioconversion of triploid poplar. Process Biochem. 2012, 47, 1503-1509. [CrossRef]

113. Del Rio, L.F.; Chandra, R.P.; Saddler, J.N. The effect of varying organosolv pretreatment chemicals on the physicochemical properties and cellulolytic hydrolysis of mountain pine beetle-killed lodgepole pine. Appl. Biochem. Biotechnol. 2010, 161, 1-21. [CrossRef] [PubMed]

114. Teramura, H.; Sasaki, K.; Oshima, T.; Matsuda, F.; Okamoto, M.; Shirai, T.; Kawaguchi, H.; Ogino, C.; Hirano, K.; Sazuka, T.; et al. Organosolv pretreatment of sorghum bagasse using a low concentration of hydrophobic solvents such as 1-butanol or 1-pentanol. Biotechnol. Biofuels 2016, 9, 1-11. [CrossRef] [PubMed]

115. Lancefield, C.S.; Panovic, I.; Deuss, P.J.; Barta, K.; Westwood, N.J. Pre-treatment of lignocellulosic feedstocks using biorenewable alcohols: Towards complete biomass valorisation. Green Chem. 2017, 19, 202-214. [CrossRef]

116. Ferraz, A.; Rodrguez, J.; Freer, J.; Baeza, J. Formic acid/acetone-organosolv pulping of white-rotted Pinus radiata softwood. J. Chem. Technol. Biotechnol. 2000, 75, 1190-1196. [CrossRef]

117. Ligero, P.; Villaverde, J.J.; de Vega, A.; Bao, M. Delignification of Eucalyptus globulus saplings in two organosolv systems (formic and acetic acid). Preliminary analysis of dissolved lignins. Ind. Crops Prod. 2008, 27, 110-117. [CrossRef]

118. Li, M.F.; Sun, S.N.; Xu, F.; Sun, R.C. Formic acid based organosolv pulping of bamboo (Phyllostachys acuta): Comparative characterization of the dissolved lignins with milled wood lignin. Chem. Eng. J. 2012, 179, 80-89. [CrossRef]

119. Manara, P.; Zabaniotou, A.; Vanderghem, C.; Richel, A. Lignin extraction from Mediterranean agro-wastes: Impact of pretreatment conditions on lignin chemical structure and thermal degradation behavior. Catal. Today 2014, 223, 25-34. [CrossRef]

120. Snelders, J.; Dornez, E.; Benjelloun-Mlayah, B.; Huijgen, W.J.J.; de Wild, P.J.; Gosselink, R.J.A.; Gerritsma, J.; Courtin, C.M. Biorefining of wheat straw using an acetic and formic acid based organosolv fractionation process. Bioresour. Technol. 2014, 156, 275-282. [CrossRef] [PubMed]

121. Kangas, H.; Hakala, T.K.; Tamminen, T.; Määttänen, M.; Liitiä, T.; Poppius-levlin, K. Optimisation of Acetic Acid Lignofibre Organosol Process. BioResources 2015, 10, 2699-2718. [CrossRef]

122. Barbash, V.; Poyda, V.; Deykun, I. Peracetic Acid Pulp from Annual Plants. Cellul. Chem. Technol. 2011, 45, 613-618.

123. Abeywickrama, C.J.; Timilsena, Y.P.; Rakshit, S.K.; Chrusciel, L.; Brosse, N. Rapid optimization of typha grass organosolv pretreatments using parallel microwave reactors for ethanol production. Ind. Eng. Chem. Res. 2013, 52, 1691-1697. [CrossRef] 
124. Lü, F.; Chai, L.; Shao, L.; He, P. Precise pretreatment of lignocellulose: Relating substrate modification with subsequent hydrolysis and fermentation to products and by-products. Biotechnol. Biofuels 2017, 10. [CrossRef] [PubMed]

125. Guragain, Y.N.; Bastola, K.P.; Madl, R.L.; Vadlani, P.V. Novel Biomass Pretreatment Using Alkaline Organic Solvents: A Green Approach for Biomass Fractionation and 2,3-Butanediol Production. Bioenergy Res. 2016, 9, 643-655. [CrossRef]

126. Li, S.X.; Li, M.F.; Bian, J.; Sun, S.N.; Peng, F.; Xue, Z.M. Biphasic 2-methyltetrahydrofuran/oxalic acid/water pretreatment to enhance cellulose enzymatic hydrolysis and lignin valorization. Bioresour. Technol. 2017, 243, 1105-1111. [CrossRef] [PubMed]

127. Romaní, A.; Ruiz, H.A.; Pereira, F.B.; Domingues, L.; Teixeira, J.A. Fractionation of Eucalyptus globulus wood by glycerol-water pretreatment: Optimization and modeling. Ind. Eng. Chem. Res. 2013, 52, 14342-14352. [CrossRef]

128. Martín, C.; Puls, J.; Schreiber, A.; Saake, B. Optimization of sulfuric acid-assisted glycerol pretreatment of sugarcane bagasse. Holzforschung 2013, 67, 523-530. [CrossRef]

129. Sun, F.F.; Zhao, X.; Hong, J.; Tang, Y.; Wang, L.; Sun, H.; Li, X.; Hu, J. Industrially relevant hydrolyzability and fermentability of sugarcane bagasse improved effectively by glycerol organosolv pretreatment. Biotechnol. Biofuels 2016, 9, 1-13. [CrossRef] [PubMed]

130. Meighan, B.N.; Lima, D.R.S.; Cardoso, W.J.; Baêta, B.E.L.; Adarme, O.F.H.; Santucci, B.S.; Pimenta, M.T.B.; de Aquino, S.F.; Gurgel, L.V.A. Two-stage fractionation of sugarcane bagasse by autohydrolysis and glycerol organosolv delignification in a lignocellulosic biorefinery concept. Ind. Crops Prod. 2017, 108, 431-441. [CrossRef]

131. Tabasso, S.; Grillo, G.; Carnaroglio, D.; Gaudino, E.C.; Cravotto, G. Microwave-Assisted $\gamma$-Valerolactone Production for Biomass Lignin Extraction: A Cascade Protocol. Molecules 2016, 21. [CrossRef] [PubMed]

132. Zhou, H.; Zhang, R.; Zhan, W.; Wang, L.; Guo, L.; Liu, Y. High biomass loadings of $40 \mathrm{wt} \%$ for efficient fractionation in biorefineries with an aqueous solvent system without adding adscititious catalyst. Green Chem. 2016, 18, 6108-6114. [CrossRef]

133. Angelini, S.; Ingles, D.; Gelosia, M.; Cerruti, P.; Pompili, E.; Scarinzi, G.; Cavalaglio, G.; Cotana, F.; Malinconico, M. One-pot lignin extraction and modification in $\gamma$-valerolactone from steam explosion pre-treated lignocellulosic biomass. J. Clean. Prod. 2017, 151, 152-162. [CrossRef]

134. Gelosia, M.; Ingles, D.; Pompili, E.; D’Antonio, S.; Cavalaglio, G.; Petrozzi, A.; Coccia, V. Fractionation of lignocellulosic residues coupling steam explosion and organosolv treatments using green solvent-Valerolactone. Energies 2017, 10. [CrossRef]

135. Trevorah, R.M.; Huynh, T.; Vancov, T.; Othman, M.Z. Bioethanol potential of Eucalyptus obliqua sawdust using gamma-valerolactone fractionation. Bioresour. Technol. 2018, 250, 673-682. [CrossRef] [PubMed]

136. Mäki-Arvela, P.; Anugwom, I.; Virtanen, P.; Sjöholm, R.; Mikkola, J.P. Dissolution of lignocellulosic materials and its constituents using ionic liquids-A review. Ind. Crops Prod. 2010, 32, 175-201. [CrossRef]

137. Zavrel, M.; Bross, D.; Funke, M.; Büchs, J.; Spiess, A.C. High-throughput screening for ionic liquids dissolving (ligno-)cellulose. Bioresour. Technol. 2009, 100, 2580-2587. [CrossRef] [PubMed]

138. Yamada, H.; Miyafuji, H.; Ohno, H.; Yamada, T. Rapid and complete dissolution of softwood biomass in tetra-n-butylphosphonium hydroxide with hydrogen peroxide. BioResources 2017, 12, 4515-4526. [CrossRef]

139. Glas, D.; Van Doorslaer, C.; Depuydt, D.; Liebner, F.; Rosenau, T.; Binnemans, K.; De Vos, D.E. Lignin solubility in non-imidazolium ionic liquids. J. Chem. Technol. Biotechnol. 2015, 90, 1821-1826. [CrossRef]

140. Schrems, M.; Brandt, A.; Welton, T.; Liebner, F.; Rosenau, T.; Potthast, A. Ionic liquids as media for biomass processing: Opportunities and restrictions. Holzforschung 2011, 65, 527-533. [CrossRef]

141. Casas, A.; Oliet, M.; Alonso, M.V.; Rodríguez, F. Dissolution of Pinus radiata and Eucalyptus globulus woods in ionic liquids under microwave radiation: Lignin regeneration and characterization. Sep. Purif. Technol. 2012, 97, 115-122. [CrossRef]

142. Hossain, M.M.; Aldous, L. Ionic liquids for lignin processing: Dissolution, isolation, and conversion. Aust. J. Chem. 2012, 65, 1465-1477. [CrossRef]

143. Cox, B.J.; Ekerdt, J.G. Pretreatment of yellow pine in an acidic ionic liquid: Extraction of hemicellulose and lignin to facilitate enzymatic digestion. Bioresour. Technol. 2013, 134, 59-65. [CrossRef] [PubMed] 
144. Wang, Y.; Wei, L.; Li, K.; Ma, Y.; Ma, N.; Ding, S.; Wang, L.; Zhao, D.; Yan, B.; Wan, W.; et al. Lignin dissolution in dialkylimidazolium-based ionic liquid-water mixtures. Bioresour. Technol. 2014, 170, 499-505. [CrossRef] [PubMed]

145. Mohtar, S.S.; Tengku Malim Busu, T.N.Z.; Md Noor, A.M.; Shaari, N.; Yusoff, N.A.; Bustam Khalil, M.A.; Abdul Mutalib, M.I.; Mat, H.B. Extraction and characterization of lignin from oil palm biomass via ionic liquid dissolution and non-toxic aluminium potassium sulfate dodecahydrate precipitation processes. Bioresour. Technol. 2015, 192, 212-218. [CrossRef] [PubMed]

146. Pang, Z.; Lyu, W.; Dong, C.; Li, H.; Yang, G. High selective delignification using oxidative ionic liquid pretreatment at mild conditions for efficient enzymatic hydrolysis of lignocellulose. Bioresour. Technol. 2016, 214, 96-101. [CrossRef] [PubMed]

147. Zakaria, S.M.; Idris, A.; Alias, Y. Lignin extraction from coconut shell using aprotic ionic liquids. BioResources 2017, 12, 5749-5774. [CrossRef]

148. Akiba, T.; Tsurumaki, A.; Ohno, H. Induction of lignin solubility for a series of polar ionic liquids by the addition of a small amount of water. Green Chem. 2017, 19, 2260-2265. [CrossRef]

149. Achinivu, E. Protic Ionic Liquids for Lignin Extraction-A Lignin Characterization Study. Int. J. Mol. Sci. 2018, 19. [CrossRef] [PubMed]

150. Underkofler, K.A.; Teixeira, R.E.; Pietsch, S.A.; Knapp, K.G.; Raines, R.T. Separation of lignin from corn stover hydrolysate with quantitative recovery of ionic liquid. ACS Sustain. Chem. Eng. 2015, 3, 606-613. [CrossRef] [PubMed]

151. Viell, J.; Inouye, H.; Szekely, N.K.; Frielinghaus, H.; Marks, C.; Wang, Y.; Anders, N.; Spiess, A.C.; Makowski, L. Multi-scale processes of beech wood disintegration and pretreatment with 1-ethyl-3-methylimidazolium acetate/water mixtures. Biotechnol. Biofuels 2016, 9. [CrossRef] [PubMed]

152. Magalhães da Silva, S.P.; da Costa Lopes, A.M.; Roseiro, L.B.; Bogel-Łukasik, R. Novel pre-treatment and fractionation method for lignocellulosic biomass using ionic liquids. RSC Adv. 2013, 3. [CrossRef]

153. Konda, N.M.; Shi, J.; Singh, S.; Blanch, H.W.; Simmons, B.A.; Klein-Marcuschamer, D. Understanding cost drivers and economic potential of two variants of ionic liquid pretreatment for cellulosic biofuel production. Biotechnol. Biofuels 2014, 7, 1-11. [CrossRef] [PubMed]

154. Van Osch, D.J.G.P.; Kollau, L.J.B.M.; van den Bruinhorst, A.; Asikainen, S.; Rocha, M.A.A.; Kroon, M.C. Ionic liquids and deep eutectic solvents for lignocellulosic biomass fractionation. Phys. Chem. Chem. Phys. 2017, 19, 2636-2665. [CrossRef] [PubMed]

155. Soares, B.; Tavares, D.J.P.; Amaral, J.L.; Silvestre, A.J.D.; Freire, C.S.R.; Coutinho, J.A.P. Enhanced Solubility of Lignin Monomeric Model Compounds and Technical Lignins in Aqueous Solutions of Deep Eutectic Solvents. ACS Sustain. Chem. Eng. 2017, 5, 4056-4065. [CrossRef]

156. Kumar, A.K.; Parikh, B.S.; Pravakar, M. Natural deep eutectic solvent mediated pretreatment of rice straw: Bioanalytical characterization of lignin extract and enzymatic hydrolysis of pretreated biomass residue. Environ. Sci. Pollut. Res. 2016, 23, 9265-9275. [CrossRef] [PubMed]

157. Wahlström, R.; Hiltunen, J.; Pitaluga de Souza Nascente Sirkka, M.; Vuoti, S.; Kruus, K. Comparison of three deep eutectic solvents and 1-ethyl-3-methylimidazolium acetate in the pretreatment of lignocellulose: effect on enzyme stability, lignocellulose digestibility and one-pot hydrolysis. RSC Adv. 2016, 6, 68100-68110. [CrossRef]

158. Zulkefli, S.; Abdulmalek, E.; Abdul Rahman, M.B. Pretreatment of oil palm trunk in deep eutectic solvent and optimization of enzymatic hydrolysis of pretreated oil palm trunk. Renew. Energy 2017, 107, 36-41. [CrossRef]

159. Lynam, J.G.; Kumar, N.; Wong, M.J. Deep eutectic solvents' ability to solubilize lignin, cellulose, and hemicellulose; thermal stability; and density. Bioresour. Technol. 2017, 238, 684-689. [CrossRef] [PubMed]

160. Tian, D.; Chandra, R.P.; Lee, J.S.; Lu, C.; Saddler, J.N. A comparison of various lignin-extraction methods to enhance the accessibility and ease of enzymatic hydrolysis of the cellulosic component of steam-pretreated poplar. Biotechnol. Biofuels 2017, 10, 1-10. [CrossRef] [PubMed]

161. Procentese, A.; Johnson, E.; Orr, V.; Garruto Campanile, A.; Wood, J.A.; Marzocchella, A.; Rehmann, L. Deep eutectic solvent pretreatment and subsequent saccharification of corncob. Bioresour. Technol. 2015, 192, 31-36. [CrossRef] [PubMed] 
162. Alvarez-Vasco, C.; Ma, R.; Quintero, M.; Guo, M.; Geleynse, S.; Ramasamy, K.K.; Wolcott, M.; Zhang, X. Unique low-molecular-weight lignin with high purity extracted from wood by deep eutectic solvents (DES): A source of lignin for valorization. Green Chem. 2016, 18, 5133-5141. [CrossRef]

163. Pan, M.; Zhao, G.; Ding, C.; Wu, B.; Lian, Z.; Lian, H. Physicochemical transformation of rice straw after pretreatment with a deep eutectic solvent of choline chloride/urea. Carbohydr. Polym. 2017, 176, 307-314. [CrossRef] [PubMed]

164. Skulcova, A.; Majova, V.; Kohutova, M.; Grosik, M.; Sima, J.; Jablonsky, M. UV/Vis Spectrometry as a quantification tool for lignin solubilized in deep eutectic solvents. BioResources 2017, 12, 6713-6722. [CrossRef]

165. Li, T.; Lyu, G.; Liu, Y.; Lou, R.; Lucia, L.A.; Yang, G.; Chen, J.; Saeed, H.A.M. Deep eutectic solvents (DESs) for the isolation of willow lignin (salix matsudana cv. zhuliu). Int. J. Mol. Sci. 2017, 18. [CrossRef] [PubMed]

166. Chen, Z.; Wan, C. Ultrafast fractionation of lignocellulosic biomass by microwave-assisted deep eutectic solvent pretreatment. Bioresour. Technol. 2018, 250, 532-537. [CrossRef] [PubMed]

167. Xing, W.; Xu, G.; Dong, J.; Han, R.; Ni, Y. Novel dihydrogen-bonding deep eutectic solvents: Pretreatment of rice straw for butanol fermentation featuring enzyme recycling and high solvent yield. Chem. Eng. J. 2018, 333, 712-720. [CrossRef]

168. Yu, Q.; Zhang, A.; Wang, W.; Chen, L.; Bai, R.; Zhuang, X.; Wang, Q.; Wang, Z.; Yuan, Z. Deep eutectic solvents from hemicellulose-derived acids for the cellulosic ethanol refining of Akebia herbal residues. Bioresour. Technol. 2018, 247, 705-710. [CrossRef]

169. Hiltunen, J.; Kuutti, L.; Rovio, S.; Puhakka, E.; Virtanen, T.; Ohra-Aho, T.; Vuoti, S. Using a low melting solvent mixture to extract value from wood biomass. Sci. Rep. 2016, 6. [CrossRef] [PubMed]

170. Abdelaziz, O.Y.; Hulteberg, C.P. Physicochemical Characterisation of Technical Lignins for Their Potential Valorisation. Waste Biomass Valorization 2017, 8, 859-869. [CrossRef]

171. Yuan, T.Q.; Xu, F.; Sun, R.C. Role of lignin in a biorefinery: Separation characterization and valorization. J. Chem. Technol. Biotechnol. 2013, 88, 346-352. [CrossRef]

172. Constant, S.; Wienk, H.L.J.; Frissen, A.E.; de Peinder, P.; Boelens, R.; van Es, D.S.; Grisel, R.J.H.; Weckhuysen, B.M.; Huijgen, W.J.J.; Gosselink, R.J.A.; et al. New insights into the structure and composition of technical lignins: A comparative characterisation study. Green Chem. 2016, 18, 2651-2665. [CrossRef]

173. Zhang, L.; Yan, L.; Wang, Z.; Laskar, D.D.; Swita, M.S.; Cort, J.R.; Yang, B. Characterization of lignin derived from water-only and dilute acid flowthrough pretreatment of poplar wood at elevated temperatures. Biotechnol. Biofuels 2015, 8, 1-14. [CrossRef] [PubMed]

174. Li, Z.; Bansal, N.; Azarpira, A.; Bhalla, A.; Chen, C.H.; Ralph, J.; Hegg, E.L.; Hodge, D.B. Chemical and structural changes associated with $\mathrm{Cu}$-catalyzed alkaline-oxidative delignification of hybrid poplar. Biotechnol. Biofuels 2015, 8, 1-12. [CrossRef] [PubMed]

175. Santos, J.I.; Martín-Sampedro, R.; Fillat, Ú.; Oliva, J.M.; Negro, M.J.; Ballesteros, M.; Eugenio, M.E.; Ibarra, D. Evaluating lignin-rich residues from biochemical ethanol production of wheat straw and olive tree pruning by FTIR and 2d-nmr. Int. J. Polym. Sci. 2015. [CrossRef]

176. Costa, C.A.E.; Pinto, P.C.R.; Rodrigues, A.E. Evaluation of chemical processing impact on E. globulus wood lignin and comparison with bark lignin. Ind. Crops Prod. 2014, 61, 479-491. [CrossRef]

177. Guragain, Y.N.; Herrera, A.I.; Vadlani, P.V.; Prakash, O. Lignins of Bioenergy Crops: A Review. Nat. Prod. Commun. 2015, 10, 201-208. [PubMed]

178. Lange, H.; Rulli, F.; Crestini, C. Gel Permeation Chromatography in Determining Molecular Weights of Lignins: Critical Aspects Revisited for Improved Utility in the Development of Novel Materials. ACS Sustain. Chem. Eng. 2016, 4, 5167-5180. [CrossRef]

179. Tolbert, A.; Akinosho, H.; Khunsupat, R.; Naskar, A.K.; Ragauskas, A.J. Characterization and analysis of the molecular weight of lignin for biorefining studies. Biofuels Bioprod. Biorefin. 2014, 8, 836-856. [CrossRef]

180. Chen, F.; Li, J. Aqueous gel permeation chromatographic methods for technical lignins. J. Wood Chem. Technol. 2000, 20, 265-276. [CrossRef]

181. González, A.M.; Salager, J.L.; Brunetto, M.R.; Gallignani, M.; Burguera, J.L.; Burguera, M.; Petit de Peña, Y. Determination of Molecular Weight Distribution of Lignin Derivatives by Aqueous Phase High Performance Size Exclusion Chromatography (HPSEC). J. High Resolut. Chromatogr. 2000, 23, 693-696. [CrossRef]

182. Gosselink, R.J.A.; Abächerli, A.; Semke, H.; Malherbe, R.; Käuper, P.; Nadif, A.; Van Dam, J.E.G. Analytical protocols for characterisation of sulphur-free lignin. Ind. Crops Prod. 2004, 19, 271-281. [CrossRef] 
183. Tao, Y.; Li, S.; Li, P.; Wu, Q. Thermogravimetric analyses (TGA) of lignins isolated from the residue of corn stover bioethanol (CSB) production. Holzforschung 2016, 70, 1175-1182. [CrossRef]

184. Koullas, D.P.; Koukios, E.G.; Avgerinos, E.; Abaecherli, A.; Gosselink, R.; Vasile, C.; Lehnen, R.; Saake, B.; Suren, J. Analytical methods for lignin characterization-Differential scanning calorimetry. Cellul. Chem. Technol. 2006, 40, 719-725.

185. Awal, A.; Sain, M. Spectroscopic Studies and Evaluation of Thermorheological Properties of Softwood and Hardwood Lignin. J. Appl. Polym. Sci. 2011, 122, 956-963. [CrossRef]

186. Espinoza-Acosta, J.L.; Torres-Chávez, P.I.; Ramírez-Wong, B.; López-Saiz, C.M.; Montaño-Leyva, B. Antioxidant, antimicrobial, and antimutagenic properties of technical lignins and their applications. BioResources 2016, 11, 5452-5481. [CrossRef]

187. Coral Medina, J.D.; Woiciechowski, A.L.; Zandona Filho, A.; Bissoqui, L.; Noseda, M.D.; de Souza Vandenberghe, L.P.; Zawadzki, S.F.; Soccol, C.R. Biological activities and thermal behavior of lignin from oil palm empty fruit bunches as potential source of chemicals of added value. Ind. Crops Prod. 2016, 94, 630-637. [CrossRef]

188. Kaur, R.; Uppal, S.K.; Sharma, P. Antioxidant and Antibacterial Activities of Sugarcane Bagasse Lignin and Chemically Modified Lignins. Sugar Tech 2017, 19, 675-680. [CrossRef]

189. Pandey, M.P.; Kim, C.S. Lignin Depolymerization and Conversion: A Review of Thermochemical Methods. Chem. Eng. Technol. 2011, 34, 29-41. [CrossRef]

190. Sun, Z.; Fridrich, B.; De Santi, A.; Elangovan, S.; Barta, K. Bright Side of Lignin Depolymerization: Toward New Platform Chemicals. Chem. Rev. 2018, 118, 614-678. [CrossRef] [PubMed]

191. De Wild, P.; Van der Laan, R.; Kloekhorst, A.; Heeres, E. Lignin valorisation for chemicals and (transportation) fuels via (catalytic) pyrolysis and hydrodeoxygenation. Environ. Prog. Sustain. Energy 2009, 28, 461-469. [CrossRef]

192. Kan, T.; Strezov, V.; Evans, T.J. Lignocellulosic biomass pyrolysis: A review of product properties and effects of pyrolysis parameters. Renew. Sustain. Energy Rev. 2016, 57, 126-1140. [CrossRef]

193. Singh, R.; Krishna, B.B.; Mishra, G.; Kumar, J.; Bhaskar, T. Strategies for selection of thermo-chemical processes for the valorisation of biomass. Renew. Energy 2016, 98, 226-237. [CrossRef]

194. Akhtar, J.; Saidina Amin, N. A review on operating parameters for optimum liquid oil yield in biomass pyrolysis. Renew. Sustain. Energy Rev. 2012, 16, 5101-5109. [CrossRef]

195. Huang, Y.; Wei, Z.; Yin, X.; Wu, C. Pyrolytic characteristics of biomass acid hydrolysis residue rich in lignin. Bioresour. Technol. 2012, 103, 470-476. [CrossRef] [PubMed]

196. Kim, J.; Lee, J.; Kim, K.H.; Ok, Y.S.; Jeon, Y.J.; Kwon, E.E. Pyrolysis of wastes generated through saccharification of oak tree by using $\mathrm{CO}_{2}$ as reaction medium. Appl. Therm. Eng. 2017, 110, 335-345. [CrossRef]

197. Kalyani, D.C.; Fakin, T.; Horn, S.J.; Tschentscher, R. Valorisation of woody biomass by combining enzymatic saccharification and pyrolysis. Green Chem. 2017, 19, 3302-3312. [CrossRef]

198. Feng, S.; Cheng, S.; Yuan, Z.; Leitch, M.; Xu, C. Valorization of bark for chemicals and materials: A review. Renew. Sustain. Energy Rev. 2013, 26, 560-578. [CrossRef]

199. Ferreira, C.I.A.; Calisto, V.; Cuerda-Correa, E.M.; Otero, M.; Nadais, H.; Esteves, V.I. Comparative valorisation of agricultural and industrial biowastes by combustion and pyrolysis. Bioresour. Technol. 2016, 218, 918-925. [CrossRef] [PubMed]

200. Biswas, B.; Pandey, N.; Bisht, Y.; Singh, R.; Kumar, J.; Bhaskar, T. Pyrolysis of agricultural biomass residues: Comparative study of corn cob, wheat straw, rice straw and rice husk. Bioresour. Technol. 2017, 237, 57-63. [CrossRef] [PubMed]

201. He, X.; Liu, Z.; Niu, W.; Yang, L.; Zhou, T.; Qin, D.; Niu, Z.; Yuan, Q. Effects of pyrolysis temperature on the physicochemical properties of gas and biochar obtained from pyrolysis of crop residues. Energy 2018, 143, 746-756. [CrossRef]

202. Efika, C.E.; Onwudili, J.A.; Williams, P.T. Influence of heating rates on the products of high-temperature pyrolysis of waste wood pellets and biomass model compounds. Waste Manag. 2018. [CrossRef] [PubMed]

203. Giwa, A.S.; Xu, H.; Wu, J.; Li, Y.; Chang, F.; Zhang, X.; Jin, Z.; Huang, B.; Wang, K. Sustainable recycling of residues from the food waste (FW) composting plant via pyrolysis: Thermal characterization and kinetic studies. J. Clean. Prod. 2018, 180, 43-49. [CrossRef] 
204. De Wild, P.J.; den Uil, H.; Reith, J.H.; Kiel, J.H.A.; Heeres, H.J. Biomass valorisation by staged degasification. A new pyrolysis-based thermochemical conversion option to produce value-added chemicals from lignocellulosic biomass. J. Anal. Appl. Pyrolysis 2009, 85, 124-133. [CrossRef]

205. Waters, C.L.; Janupala, R.R.; Mallinson, R.G.; Lobban, L.L. Staged thermal fractionation for segregation of lignin and cellulose pyrolysis products: An experimental study of residence time and temperature effects. J. Anal. Appl. Pyrolysis 2017, 126, 380-389. [CrossRef]

206. Herron, J.A.; Vann, T.; Duong, N.; Resasco, D.E.; Crossley, S.; Lobban, L.L.; Maravelias, C.T. A Systems-Level Roadmap for Biomass Thermal Fractionation and Catalytic Upgrading Strategies. Energy Technol. 2017, 5, 130-150. [CrossRef]

207. Won, W.; Maravelias, C.T. Thermal fractionation and catalytic upgrading of lignocellulosic biomass to biofuels: Process synthesis and analysis. Renew. Energy 2017, 114, 357-366. [CrossRef]

208. Elmay, Y.; Delmotte, L.; Gadiou, R.; Le Brech, Y.; Dufour, A.; Brosse, N. Effect of pyrolysis temperature on the property modifications of lignocellulosic biomass and its components. Proceedings of 2014 the 5 th International Renewable Energy Congress (IREC), Hammamet, Tunisia, 25-27 March 2014.

209. Vanderauwera, P.F.L.P.; Wambeke, D.M.C. Valorisation of bio-oil resulting from fast pyrolysis of wood. Chem. Pap. 2014, 68, 1205-1212. [CrossRef]

210. Valle, B.; Remiro, A.; Aramburu, B.; Bilbao, J.; Gayubo, A.G. Strategies for maximizing the bio-oil valorization by catalytic transformation. J. Clean. Prod. 2015, 88,345-348. [CrossRef]

211. Amutio, M.; Onaindi, A.; López, G.; Artetxe, M.; Elordi, G.; Aguado, R.; Olazar, M. Upgrading of tars from waste valorisation processes by HPLC fractionation: Scale up from analytical to preparative. In Proceedings of the 19th International Congress of Chemical and Process Engineering, CHISA 2010 7th European Congress of Chemical Engineering, ECCE-7, Prague, Czech Republic, 28 August-1 September2010.

212. Zhang, H.; Xiao, R.; Wang, D.; He, G.; Shao, S.; Zhang, J.; Zhong, Z. Biomass fast pyrolysis in a fluidized bed reactor under $\mathrm{N}_{2}, \mathrm{CO}_{2}, \mathrm{CO}, \mathrm{CH}_{4}$ and $\mathrm{H}_{2}$ atmospheres. Bioresour. Technol. 2011, 102, 4258-4264. [CrossRef] [PubMed]

213. Tarves, P.C.; Mullen, C.A.; Boateng, A.A. Effects of Various Reactive Gas Atmospheres on the Properties of Bio-Oils Produced Using Microwave Pyrolysis. ACS Sustain. Chem. Eng. 2016, 4, 930-936. [CrossRef]

214. Pütün, E.; Ateş, F.; Pütün, A.E. Catalytic pyrolysis of biomass in inert and steam atmospheres. Fuel 2008, 87, 815-824. [CrossRef]

215. Önal, E.; Uzun, B.B.; Pütün, A.E. The effect of pyrolysis atmosphere on bio-oil yields and structure. Int. J. Green Energy 2017, 14, 1-8. [CrossRef]

216. De Wild, P.J.; Huijgen, W.J.J.; Heeres, H.J. Pyrolysis of wheat straw-derived organosolv lignin. J. Anal. Appl. Pyrolysis 2012, 93, 95-103. [CrossRef]

217. De Wild, P.J.; Huijgen, W.J.J.; Gosselink, R.J.A. Lignin pyrolysis for profi table lignocellulosic biorefineries. Biofuels Bioprod. Biorefin. 2014, 8, 645-657. [CrossRef]

218. Zhou, S.; Xue, Y.; Sharma, A.; Bai, X. Lignin Valorization through Thermochemical Conversion: Comparison of Hardwood, Softwood and Herbaceous Lignin. ACS Sustain. Chem. Eng. 2016, 4, 6608-6617. [CrossRef]

219. Tomás-Pejó, E.; Fermoso, J.; Herrador, E.; Hernando, H.; Jiménez-Sánchez, S.; Ballesteros, M.; González-Fernández, C.; Serrano, D.P. Valorization of steam-exploded wheat straw through a biorefinery approach: Bioethanol and bio-oil co-production. Fuel 2017, 199, 403-412. [CrossRef]

220. Xu, L.; Yao, Q.; Zhang, Y.; Fu, Y. Integrated Production of Aromatic Amines and N-Doped Carbon from Lignin via ex Situ Catalytic Fast Pyrolysis in the Presence of Ammonia over Zeolites. ACS Sustain. Chem. Eng. 2017, 5, 2960-2969. [CrossRef]

221. Moliner, C.; Bosio, B.; Arato, E.; Ribes-Greus, A. Comparative study for the energy valorisation of rice straw. Chem. Eng. Trans. 2014, 37, 241-246. [CrossRef]

222. Amutio, M.; Lopez, G.; Alvarez, J.; Moreira, R.; Duarte, G.; Nunes, J.; Olazar, M.; Bilbao, J. Pyrolysis kinetics of forestry residues from the Portuguese Central Inland Region. Chem. Eng. Res. Des. 2013, 91, 2682-2690. [CrossRef]

223. Manara, P.; Vamvuka, D.; Sfakiotakis, S.; Vanderghem, C.; Richel, A.; Zabaniotou, A. Mediterranean agri-food processing wastes pyrolysis after pre-treatment and recovery of precursor materials: A TGA-based kinetic modeling study. Food Res. Int. 2015, 73, 44-51. [CrossRef]

224. Ojha, D.K.; Viju, D.; Vinu, R. Fast pyrolysis kinetics of alkali lignin: Evaluation of apparent rate parameters and product time evolution. Bioresour. Technol. 2017, 241, 142-151. [CrossRef] [PubMed] 
225. Faravelli, T.; Frassoldati, A.; Migliavacca, G.; Ranzi, E. Detailed kinetic modeling of the thermal degradation of lignins. Biomass Bioenergy 2010, 34, 290-301. [CrossRef]

226. Hough, B.R.; Schwartz, D.T.; Pfaendtner, J. Detailed Kinetic Modeling of Lignin Pyrolysis for Process Optimization. Ind. Eng. Chem. Res. 2016, 55, 9147-9153. [CrossRef]

227. Wang, S.; Dai, G.; Yang, H.; Luo, Z. Lignocellulosic biomass pyrolysis mechanism: A state-of-the-art review. Prog. Energy Combust. Sci. 2017, 62, 33-86. [CrossRef]

228. Parascanu, M.M.; Sandoval-Salas, F.; Soreanu, G.; Valverde, J.L.; Sanchez-Silva, L. Valorization of Mexican biomasses through pyrolysis, combustion and gasification processes. Renew. Sustain. Energy Rev. 2017, 71, 509-522. [CrossRef]

229. Tian, T.; Li, Q.; He, R.; Tan, Z.; Zhang, Y. Effects of biochemical composition on hydrogen production by biomass gasification. Int. J. Hydrogen Energy 2017, 42, 19723-19732. [CrossRef]

230. Marrugo, G.; Valdés, C.F.; Chejne, F. Biochar Gasification: An Experimental Study on Colombian Agroindustrial Biomass Residues in a Fluidized Bed. Energy Fuels 2017, 31, 9408-9421. [CrossRef]

231. Yamaguchi, A. Biomass valorization in high-temperature liquid water. J. Jpn. Pet. Inst. 2014, 57, $155-163$. [CrossRef]

232. Akay, G.; Jordan, C.A. Gasification of fuel cane bagasse in a downdraft gasifier: Influence of lignocellulosic composition and fuel particle size on syngas composition and yield. Energy Fuels 2011, 25, 2274-2283. [CrossRef]

233. Cerone, N.; Zimbardi, F.; Contuzzi, L.; Prestipino, M.; Carnevale, M.O.; Valerio, V. Air-steam and oxy-steam gasification of hydrolytic residues from biorefinery. Fuel Process. Technol. 2017, 167, 451-461. [CrossRef]

234. Öhrman, O.G.W.; Weiland, F.; Pettersson, E.; Johansson, A.C.; Hedman, H.; Pedersen, M. Pressurized oxygen blown entrained flow gasification of a biorefinery lignin residue. Fuel Process. Technol. 2013, 115, 130-138. [CrossRef]

235. Pinto, F.; André, R.N.; Carolino, C.; Miranda, M.; Abelha, P.; Direito, D.; Dohrup, J.; Sørensen, H.R.; Girio, F. Effects of experimental conditions and of addition of natural minerals on syngas production from lignin by oxy-gasification: Comparison of bench- and pilot scale gasification. Fuel 2015, 140, 62-72. [CrossRef]

236. Isha, R.; Williams, P.T. Pyrolysis-gasification of agriculture biomass wastes for hydrogen production. J. Energy Inst. 2011, 84, 80-87. [CrossRef]

237. Farzaneh, A.; Richards, T.; Sklavounos, E.; Van Heiningen, A. A Kinetic Study of $\mathrm{CO}_{2}$ and Steam Gasification of Char from Lignin Produced in the SEW Process. BioResources 2014, 9, 3052-3063. [CrossRef]

238. Nanda, S.; Isen, J.; Dalai, A.K.; Kozinski, J.A. Gasification of fruit wastes and agro-food residues in supercritical water. Energy Convers. Manag. 2016, 110, 296-306. [CrossRef]

239. Rodriguez Correa, C.; Kruse, A. Supercritical water gasification of biomass for hydrogen production-Review. J. Supercrit. Fluids 2018, 133, 573-590. [CrossRef]

240. Molino, A.; Larocca, V.; Valerio, V.; Rimauro, J.; Marino, T.; Casella, P.; Cerbone, A.; Arcieri, G.; Viola, E. Supercritical water gasification of lignin solution produced by steam explosion process on Arundo Donax after alkaline extraction. Fuel 2018, 221, 513-517. [CrossRef]

241. Lv, D.; Xu, M.; Liu, X.; Zhan, Z.; Li, Z.; Yao, H. Effect of cellulose, lignin, alkali and alkaline earth metallic species on biomass pyrolysis and gasification. Fuel Process. Technol. 2010, 91, 903-909. [CrossRef]

242. Koven, A.B.; Tong, S.S.; Farnood, R.R.; Jia, C.Q. Alkali-thermal gasification and hydrogen generation potential of biomass. Front. Chem. Sci. Eng. 2017, 11, 369-378. [CrossRef]

243. Kang, K.; Azargohar, R.; Dalai, A.K.; Wang, H. Hydrogen generation via supercritical water gasification of lignin using Ni-Co/Mg-Al catalysts. Int. J. Energy Res. 2017, 41, 1835-1846. [CrossRef]

244. Yamaguchi, A.; Hiyoshi, N.; Sato, O.; Osada, M.; Shirai, M. Lignin gasification over supported ruthenium trivalent salts in supercritical water. Energy Fuels 2008, 22, 1485-1492. [CrossRef]

245. Yamaguchi, A.; Hiyoshi, N.; Sato, O.; Osada, M.; Shirai, M. EXAFS study on structural change of charcoal-supported ruthenium catalysts during lignin gasification in supercritical water. Catal. Lett. 2008, 122, 188-195. [CrossRef]

246. Yamaguchi, A.; Hiyoshi, N.; Sato, O.; Osada, M.; Shirai, M. Lignin Gasification over Charcoal-supported Palladium and Nickel Bimetal Catalysts in Supercritical Water. Chem. Lett. 2010, 39, 1251-1253. [CrossRef]

247. Yamaguchi, A.; Hiyoshi, N.; Sato, O.; Shirai, M. Gasification of organosolv-lignin over charcoal supported noble metal salt catalysts in supercritical water. Top. Catal. 2012, 55, 889-896. [CrossRef] 
248. Consonni, S.; Katofsky, R.E.; Larson, E.D. A gasification-based biorefinery for the pulp and paper industry. Chem. Eng. Res. Des. 2009, 87, 1293-1317. [CrossRef]

249. Tock, L.; Gassner, M.; Maréchal, F. Thermochemical production of liquid fuels from biomass: Thermo-economic modeling, process design and process integration analysis. Biomass Bioenergy 2010, 34, 1838-1854. [CrossRef]

250. Hanaoka, T.; Fujimoto, S.; Yoshida, M. Efficiency Estimation and Improvement of the 1,3-Butadiene Production Process from Lignin via Syngas through Process Simulation. Energy Fuels 2017, 31, 12965-12976. [CrossRef]

251. Jiang, Z.; Hu, C. Selective extraction and conversion of lignin in actual biomass to monophenols: A review. J. Energy Chem. 2016, 25, 947-956. [CrossRef]

252. Toor, S.S.; Rosendahl, L.; Rudolf, A. Hydrothermal liquefaction of biomass: A review of subcritical water technologies. Energy 2011, 36, 2328-2342. [CrossRef]

253. Diono, W.; Sasaki, M.; Goto, M. Recovery of phenolic compounds through the decomposition of lignin in near and supercritical water. Chem. Eng. Process. 2008, 47, 1609-1619. [CrossRef]

254. Wahyudiono, W.; Machmudah, S.; Goto, M. Utilization of sub and supercritical water reactions in resource recovery of biomass wastes. Eng. J. 2013, 17, 1-12. [CrossRef]

255. Déniel, M.; Haarlemmer, G.; Roubaud, A.; Weiss-Hortala, E.; Fages, J. Modelling and Predictive Study of Hydrothermal Liquefaction: Application to Food Processing Residues. Waste Biomass Valorization 2017, 8 , 2087-2107. [CrossRef]

256. Forchheim, D.; Hornung, U.; Kruse, A.; Sutter, T. Kinetic Modelling of Hydrothermal Lignin Depolymerisation. Waste Biomass Valorization 2014, 5, 985-994. [CrossRef]

257. Nielsen, J.B.; Jensen, A.; Madsen, L.R.; Larsen, F.H.; Felby, C.; Jensen, A.D. Noncatalytic Direct Liquefaction of Biorefinery Lignin by Ethanol. Energy Fuels 2017, 31, 7223-7233. [CrossRef]

258. Ma, X.; Cui, K.; Hao, W.; Ma, R.; Tian, Y.; Li, Y. Alumina supported molybdenum catalyst for lignin valorization: Effect of reduction temperature. Bioresour. Technol. 2015, 192, 17-22. [CrossRef] [PubMed]

259. Yang, J.; Zhao, L.; Liu, C.; Wang, Y.; Dai, L. Catalytic ethanolysis and gasification of kraft lignin into aromatic alcohols and $\mathrm{H}_{2}$-rich gas over $\mathrm{Rh}$ supported on $\mathrm{La}_{2} \mathrm{O}_{3} / \mathrm{CeO}_{2}-\mathrm{ZrO}_{2}$. Bioresour. Technol. 2016, 218, 926-933. [CrossRef] [PubMed]

260. Chen, M.; Hao, W.; Ma, R.; Ma, X.; Yang, L.; Yan, F.; Cui, K.; Chen, H.; Li, Y. Catalytic ethanolysis of Kraft lignin to small-molecular liquid products over an alumina supported molybdenum nitride catalyst. Catal. Today 2017, 298, 9-15. [CrossRef]

261. Huang, X.; Atay, C.; Zhu, J.; Palstra, S.W.L.; Korányi, T.I.; Boot, M.D.; Hensen, E.J.M. Catalytic Depolymerization of Lignin and Woody Biomass in Supercritical Ethanol: Influence of Reaction Temperature and Feedstock. ACS Sustain. Chem. Eng. 2017, 5, 10864-10874. [CrossRef] [PubMed]

262. Chen, Y.; Wang, F.; Jia, Y.; Yang, N.; Zhang, X. One-step ethanolysis of lignin into small-molecular aromatic hydrocarbons over nano-SiC catalyst. Bioresour. Technol. 2017, 226, 145-149. [CrossRef] [PubMed]

263. Long, J.; Lou, W.; Wang, L.; Yin, B.; Li, X. $\left[\mathrm{C}_{4} \mathrm{H}_{8} \mathrm{SO}_{3} \mathrm{Hmim}\right] \mathrm{HSO}_{4}$ as an efficient catalyst for direct liquefaction of bagasse lignin: Decomposition properties of the inner structural units. Chem. Eng. Sci. 2015, 122, $24-33$. [CrossRef]

264. Renders, T.; Van Den Bosch, S.; Vangeel, T.; Ennaert, T.; Koelewijn, S.F.; Van Den Bossche, G.; Courtin, C.M.; Schutyser, W.; Sels, B.F. Synergetic Effects of Alcohol/Water Mixing on the Catalytic Reductive Fractionation of Poplar Wood. ACS Sustain. Chem. Eng. 2016, 4, 6894-6904. [CrossRef]

265. Xu, J.; Xie, X.; Wang, J.; Jiang, J. Directional liquefaction coupling fractionation of lignocellulosic biomass for platform chemicals. Green Chem. 2016, 18, 3124-3138. [CrossRef]

266. Gosselink, R.J.A.; Teunissen, W.; van Dam, J.E.G.; de Jong, E.; Gellerstedt, G.; Scott, E.L.; Sanders, J.P.M. Lignin depolymerisation in supercritical carbon dioxide/acetone/water fluid for the production of aromatic chemicals. Bioresour. Technol. 2012, 106, 173-177. [CrossRef] [PubMed]

267. Briones, R.; Serrano, L.; Sequeiros, A.; Labidi, J. Influence of microwave heating on chemical properties of liquefied lignocellulosic residues. Ind. Eng. Chem. Res. 2013, 52, 2755-2761. [CrossRef]

268. Dhar, P.; Vinu, R. Understanding lignin depolymerization to phenols via microwave-assisted solvolysis process. J. Environ. Chem. Eng. 2017, 5, 4759-4768. [CrossRef] 
269. Varanasi, P.; Singh, P.; Auer, M.; Adams, P.D.; Simmons, B.A.; Singh, S. Survey of renewable chemicals produced from lignocellulosic biomass during ionic liquid pretreatment. Biotechnol. Biofuels $2013,6$. [CrossRef] [PubMed]

270. Singh, S.K.; Dhepe, P.L. Ionic liquids catalyzed lignin liquefaction: Mechanistic studies using TPO-MS, FT-IR, RAMAN and 1D, 2D-HSQC/NOSEY NMR. Green Chem. 2016, 18, 4098-4108. [CrossRef]

271. Dutta, T.; Isern, N.G.; Sun, J.; Wang, E.; Hull, S.; Cort, J.R.; Simmons, B.A.; Singh, S. Survey of Lignin-Structure Changes and Depolymerization during Ionic Liquid Pretreatment. ACS Sustain. Chem. Eng. 2017, 5, 10116-10127. [CrossRef]

272. An, Y.-X.; Li, N.; Wu, H.; Lou, W.-Y.; Zong, M.-H. Changes in the Structure and the Thermal Properties of Kraft Lignin during Its Dissolution in Cholinium Ionic Liquids. ACS Sustain. Chem. Eng. 2015, 3, 2951-2958. [CrossRef]

273. Da Costa Lopes, A.M.; Da Magalhães Silva, S.P.; Carvalho, A.V.; Brenner, M.; Roseiro, L.B.; Bogel-Lukasik, R. Development of ionic liquid technologies for the integration of pre-treatment, fractionation, extraction, hydrolysis and conversion of biomass in the frame of the biorefinery concept. In European Biomass Conference and Exhibition Proceedings; ETA-Florence Renewable Energies: Amsterdam, The Netherlands, 2016; pp. 993-997.

274. Dier, T.K.F.; Rauber, D.; Durneata, D.; Hempelmann, R.; Volmer, D.A. Sustainable Electrochemical Depolymerization of Lignin in Reusable Ionic Liquids. Sci. Rep. 2017, 7, 1-12. [CrossRef] [PubMed]

275. Rauber, D.; Dier, T.K.F.; Volmer, D.A.; Hempelmann, R. Electrochemical Lignin Degradation in Ionic Liquids on Ternary Mixed Metal Electrodes. Z. Phys. Chem. 2017. [CrossRef]

276. Zhang, Z.; Song, J.; Han, B. Catalytic Transformation of Lignocellulose into Chemicals and Fuel Products in Ionic Liquids. Chem. Rev. 2017, 117, 6834-6880. [CrossRef] [PubMed]

277. Hong, S.; Lian, H.; Sun, X.; Pan, D.; Carranza, A.; Pojman, J.A.; Mota-Morales, J.D. Zinc-based deep eutectic solvent-mediated hydroxylation and demethoxylation of lignin for the production of wood adhesive. RSC Adv. 2016, 6, 89599-89608. [CrossRef]

278. Di Marino, D.; Aniko, V.; Stocco, A.; Kriescher, S.; Wessling, M. Emulsion electro-oxidation of kraft lignin. Green Chem. 2017, 19, 4778-4784. [CrossRef]

279. Harris, E.E.; D’Ianni, J.; Adkins, H. Reaction of Hardwood Lignin with Hydrogen. J. Am. Chem. Soc. 1938, 60, 1467-1470. [CrossRef]

280. Chen, X.; Yan, N. Novel Catalytic Systems to Convert Chitin and Lignin into Valuable Chemicals. Catal. Surv. Asia 2014, 18, 164-176. [CrossRef]

281. Shen, X.; Huang, P.; Wen, J.; Sun, R. Research status of lignin oxidative and reductive depolymerization. Prog. Chem. 2017, 29, 162-178.

282. Kärkäs, M.D. Lignin Hydrogenolysis: Improving Lignin Disassembly through Formaldehyde Stabilization. ChemSusChem 2017, 10, 2111-2115. [CrossRef] [PubMed]

283. Van den Bosch, S.; Schutyser, W.; Vanholme, R.; Driessen, T.; Koelewijn, S.-F.; Renders, T.; De Meester, B.; Huijgen, W.J.J.; Dehaen, W.; Courtin, C.M.; et al. Reductive lignocellulose fractionation into soluble lignin-derived phenolic monomers and dimers and processable carbohydrate pulps. Energy Environ. Sci. 2015, 8, 1748-1763. [CrossRef]

284. Shu, R.; Zhang, Q.; Ma, L.; Xu, Y.; Chen, P.; Wang, C.; Wang, T. Insight into the solvent, temperature and time effects on the hydrogenolysis of hydrolyzed lignin. Bioresour. Technol. 2016, 221, 568-575. [CrossRef] [PubMed]

285. Guo, H.; Zhang, B.; Qi, Z.; Li, C.; Ji, J.; Dai, T.; Wang, A.; Zhang, T. Valorization of Lignin to Simple Phenolic Compounds over Tungsten Carbide: Impact of Lignin Structure. ChemSusChem 2017, 10, 523-532. [CrossRef] [PubMed]

286. Ferrini, P.; Rinaldi, R. Catalytic biorefining of plant biomass to non-pyrolytic lignin bio-oil and carbohydrates through hydrogen transfer reactions. Angew. Chem. Int. Ed. 2014, 53, 8634-8639. [CrossRef] [PubMed]

287. Calvaruso, G.; Clough, M.T.; Rechulski, M.D.K.; Rinaldi, R. On the Meaning and Origins of Lignin Recalcitrance: A Critical Analysis of the Catalytic Upgrading of Lignins Obtained from Mechanocatalytic Biorefining and Organosolv Pulping. ChemCatChem 2017, 9, 2691-2700. [CrossRef]

288. Kasakov, S.; Shi, H.; Camaioni, D.M.; Zhao, C.; Baráth, E.; Jentys, A.; Lercher, J.A. Reductive deconstruction of organosolv lignin catalyzed by zeolite supported nickel nanoparticles. Green Chem. 2015, 17, 5079-5090. [CrossRef] 
289. Toledano, A.; Serrano, L.; Balu, A.M.; Luque, R.; Pineda, A.; Labidi, J. Fractionation of organosolv lignin from olive tree clippings and its valorization to simple phenolic compounds. ChemSusChem 2013, 6, 529-536. [CrossRef] [PubMed]

290. Toledano, A.; Serrano, L.; Pineda, A.; Romero, A.A.; Luque, R.; Labidi, J. Microwave-assisted depolymerisation of organosolv lignin via mild hydrogen-free hydrogenolysis: Catalyst screening. Appl. Catal. B Environ. 2014, 145, 43-55. [CrossRef]

291. Petitjean, L.; Gagne, R.; Beach, E.S.; An, J.; Anastas, P.T.; Xiao, D. Quantum Chemistry Analysis of Reaction Thermodynamics for Hydrogenation and Hydrogenolysis of Aromatic Biomass Model Compounds. ACS Sustain. Chem. Eng. 2017, 5, 10371-10378. [CrossRef]

292. Zaheer, M.; Kempe, R. Catalytic hydrogenolysis of aryl ethers: A key step in lignin valorization to valuable chemicals. ACS Catal. 2015, 5, 1675-1684. [CrossRef]

293. Stärk, K.; Taccardi, N.; Bösmann, A.; Wasserscheid, P. Oxidative depolymerization of lignin in ionic liquids. ChemSusChem 2010, 3, 719-723. [CrossRef] [PubMed]

294. Díaz-Urrutia, C.; Chen, W.-C.; Crites, C.-O.; Daccache, J.; Korobkov, I.; Baker, R.T. Towards lignin valorisation: Comparing homogeneous catalysts for the aerobic oxidation and depolymerisation of organosolv lignin. RSC Adv. 2015, 5, 70502-70511. [CrossRef]

295. De Gregorio, G.F.; Prado, R.; Vriamont, C.; Erdocia, X.; Labidi, J.; Hallett, J.P.; Welton, T. Oxidative depolymerization of lignin using a novel polyoxometalate-protic ionic liquid system. ACS Sustain. Chem. Eng. 2016, 4, 6031-6036. [CrossRef]

296. Zhang, C.; Li, H.; Lu, J.; Zhang, X.; Macarthur, K.E.; Heggen, M.; Wang, F. Promoting Lignin Depolymerization and Restraining the Condensation via an Oxidation-Hydrogenation Strategy. ACS Catal. 2017, 7, 3419-3429. [CrossRef]

297. Behling, R.; Valange, S.; Chatel, G. Heterogeneous catalytic oxidation for lignin valorization into valuable chemicals: What results? What limitations? What trends? Green Chem. 2016, 18, 1839-1854. [CrossRef]

298. Ren, X.; Wang, P.; Han, X.; Zhang, G.; Gu, J.; Ding, C.; Zheng, X.; Cao, F. Depolymerization of Lignin to Aromatics by Selectively Oxidizing Cleavage of $\mathrm{C}-\mathrm{C}$ and $\mathrm{C}-\mathrm{O}$ Bonds Using $\mathrm{CuCl}_{2} /$ Polybenzoxazine Catalysts at Room Temperature. ACS Sustain. Chem. Eng. 2017, 5, 6548-6556. [CrossRef]

299. Ma, R.; Guo, M.; Zhang, X. Recent advances in oxidative valorization of lignin. Catal. Today 2018, 302, 50-60. [CrossRef]

300. Huang, X.; Ouyang, X.; Hendriks, B.M.S.; Gonzalez, O.M.M.; Zhu, J.; Korányi, T.I.; Boot, M.D.; Hensen, E.J.M. Selective production of mono-aromatics from lignocellulose over Pd/C catalyst: The influence of acid co-catalysts. Faraday Discuss. 2017. [CrossRef] [PubMed]

301. Adler, E. Lignin chemistry-past, present and future. Wood Sci. Technol. 1977, 11, 169-218. [CrossRef]

302. Jastrzebski, R.; Constant, S.; Lancefield, C.S.; Westwood, N.J.; Weckhuysen, B.M.; Bruijnincx, P.C.A. Tandem catalytic depolymerization of lignin by water-tolerant Lewis acids and rhodium complexes. ChemSusChem 2016, 9, 2074-2079. [CrossRef] [PubMed]

303. Lahive, C.W.; Deuss, P.J.; Lancefield, C.S.; Sun, Z.; Cordes, D.B.; Young, C.M.; Tran, F.; Slawin, A.M.Z.; De Vries, J.G.; Kamer, P.C.J.; et al. Advanced Model Compounds for Understanding Acid-Catalyzed Lignin Depolymerization: Identification of Renewable Aromatics and a Lignin-Derived Solvent. J. Am. Chem. Soc. 2016, 138, 8900-8911. [CrossRef] [PubMed]

304. Pelzer, A.W.; Sturgeon, M.R.; Yanez, A.J.; Chupka, G.; O’Brien, M.H.; Katahira, R.; Cortright, R.D.; Woods, L.; Beckham, G.T.; Broadbelt, L.J. Acidolysis of $\alpha$-O-4 Aryl-Ether Bonds in Lignin Model Compounds: A Modeling and Experimental Study. ACS Sustain. Chem. Eng. 2015, 3, 1339-1347. [CrossRef]

305. Chan, M.K.; Ye, Q.; Png, Z.M.; Zeng, H.N.; Wang, X.; Xu, J. Valorization of lignin: effective conversion of depolymerized lignin to oil by simple chemical modifications. Waste Biomass Valorization 2017, 8, 2029-2036. [CrossRef]

306. Duan, D.; Zhao, Y.; Fan, L.; Dai, L.; Lv, J.; Ruan, R.; Wang, Y.; Liu, Y. Low-power microwave radiation-assisted depolymerization of ethanol organosolv lignin in ethanol/formic acid mixtures. BioResources 2017, 12, 5308-5320. [CrossRef]

307. Ma, R.; Guo, M.; Lin, K.T.; Hebert, V.R.; Zhang, J.; Wolcott, M.P.; Quintero, M.; Ramasamy, K.K.; Chen, X.; Zhang, X. Peracetic Acid Depolymerization of Biorefinery Lignin for Production of Selective Monomeric Phenolic Compounds. Chemistry 2016, 22, 10884-10891. [CrossRef] [PubMed] 
308. Deepa, A.K.; Dhepe, P.L. Lignin Depolymerization into Aromatic Monomers over Solid Acid Catalysts. ACS Catal. 2015, 5, 365-379. [CrossRef]

309. Yang, L.; Li, Y.; Savage, P.E. Hydrolytic cleavage of C-O linkages in lignin model compounds catalyzed by water-tolerant Lewis acids. Ind. Eng. Chem. Res. 2014, 53, 2633-2639. [CrossRef]

310. Shu, R.; Long, J.; Yuan, Z.; Zhang, Q.; Wang, T.; Wang, C.; Ma, L. Efficient and Product-Controlled Depolymerization of Lignin Oriented by Raney Ni Cooperated with $\mathrm{Cs}_{\mathrm{x}} \mathrm{H}_{3}-\mathrm{xPW}_{12} \mathrm{O}_{40}$. Bioresour. Technol. 2015, 179, 84-90. [CrossRef] [PubMed]

311. Shu, R.; Xu, Y.; Ma, L.; Zhang, Q.; Wang, C.; Chen, Y. Controllable production of guaiacols and phenols from lignin depolymerization using Pd/C catalyst cooperated with metal chloride. Chem. Eng. J. 2018, 338, 457-464. [CrossRef]

312. Güvenatam, B.; Heeres, E.H.J.; Pidko, E.A.; Hensen, E.J.M. Lewis-acid catalyzed depolymerization of Protobind lignin in supercritical water and ethanol. Catal. Today 2016, 259, 460-466. [CrossRef]

313. Katahira, R.; Mittal, A.; McKinney, K.; Chen, X.; Tucker, M.P.; Johnson, D.K.; Beckham, G.T. Base-Catalyzed Depolymerization of Biorefinery Lignins. ACS Sustain. Chem. Eng. 2016, 4, 1474-1486. [CrossRef]

314. Toledano, A.; Serrano, L.; Labidi, J. Organosolv lignin depolymerization with different base catalysts. J. Chem. Technol. Biotechnol. 2012, 87, 1593-1599. [CrossRef]

315. Chaudhary, R.; Dhepe, P.L. Solid base catalyzed depolymerization of lignin into low molecular weight products. Green Chem. 2017, 19, 778-788. [CrossRef]

316. Rodriguez, A.; Salvachúa, D.; Katahira, R.; Black, B.A.; Cleveland, N.S.; Reed, M.; Smith, H.; Baidoo, E.E.K.; Keasling, J.D.; Simmons, B.A.; et al. Base-Catalyzed Depolymerization of Solid Lignin-Rich Streams Enables Microbial Conversion. ACS Sustain. Chem. Eng. 2017, 5, 8171-8180. [CrossRef]

317. Kruger, J.S.; Cleveland, N.S.; Zhang, S.; Katahira, R.; Black, B.A.; Chupka, G.M.; Lammens, T.; Hamilton, P.G.; Biddy, M.J.; Beckham, G.T. Lignin Depolymerization with Nitrate-Intercalated Hydrotalcite Catalysts. ACS Catal. 2016, 6, 1316-1328. [CrossRef]

318. Toledano, A.; Serrano, L.; Labidi, J. Improving base catalyzed lignin depolymerization by avoiding lignin repolymerization. Fuel 2014, 116, 617-624. [CrossRef]

319. Roberts, V.M.; Stein, V.; Reiner, T.; Lemonidou, A.; Li, X.; Lercher, J.A. Towards quantitative catalytic lignin depolymerization. Chemistry 2011, 17, 5939-5948. [CrossRef] [PubMed]

320. Erdocia, X.; Prado, R.; Corcuera, M.Á.; Labidi, J. Base catalyzed depolymerization of lignin: Influence of organosolv lignin nature. Biomass Bioenergy 2014, 66, 379-386. [CrossRef]

321. Jensen, M.M.; Madsen, R.B.; Becker, J.; Iversen, B.B.; Glasius, M. Products of hydrothermal treatment of lignin and the importance of ortho-directed repolymerization reactions. J. Anal. Appl. Pyrolysis 2017, 126, 371-379. [CrossRef]

322. Lankau, T.; Yu, C.-H. Intermediate oxiranes in the base-catalyzed depolymerisation of lignin. Green Chem. 2016, 18, 1590-1596. [CrossRef]

323. Dabral, S.; Engel, J.; Mottweiler, J.; Spoehrle, S.; Lahive, C.W.; Bolm, C. Mechanistic Studies of Base-Catalyzed Lignin Depolymerization in Dimethyl Carbonate. Green Chem. 2017. [CrossRef]

324. Toledano, A.; Serrano, L.; Labidi, J. Extraction and revalorization of olive tree (Olea europea) pruning lignin. J. Taiwan Inst. Chem. Eng. 2013, 44, 552-559. [CrossRef]

325. Brittain, A.D.; Chrisandina, N.J.; Cooper, R.E.; Buchanan, M.; Cort, J.R.; Olarte, M.V.; Sievers, C. Quenching of reactive intermediates during mechanochemical depolymerization of lignin. Catal. Today 2016. [CrossRef]

326. Kim, H.G.; Park, Y. Manageable conversion of lignin to phenolic chemicals using a microwave reactor in the presence of potassium hydroxide. Ind. Eng. Chem. Res. 2013, 52, 10059-10062. [CrossRef]

327. Bu, Q.; Lei, H.; Zacher, A.H.; Wang, L.; Ren, S.; Liang, J.; Wei, Y.; Liu, Y.; Tang, J.; Zhang, Q.; Ruan, R. A review of catalytic hydrodeoxygenation of lignin-derived phenols from biomass pyrolysis. Bioresour. Technol. 2012, 124, 470-477. [CrossRef] [PubMed]

328. Lange, H.; Decina, S.; Crestini, C. Oxidative upgrade of lignin-Recent routes reviewed. Eur. Polym. J. 2013, 49, 1151-1173. [CrossRef]

329. Laurichesse, S.; Avérous, L. Chemical modification of lignins: Towards biobased polymers. Prog. Polym. Sci. 2014, 39, 1266-1290. [CrossRef]

330. Saidi, M.; Samimi, F.; Karimipourfard, D.; Nimmanwudipong, T.; Gates, B.C.; Rahimpour, M.R. Upgrading of lignin-derived bio-oils by catalytic hydrodeoxygenation. Energy Environ. Sci. 2014, 7, 103-129. [CrossRef] 
331. Figueiredo, P.; Lintinen, K.; Hirvonen, J.T.; Kostiainen, M.A.; Santos, H.A. Properties and chemical modifications of lignin: Towards lignin-based nanomaterials for biomedical applications. Prog. Mater. Sci. 2018, 93, 233-269. [CrossRef]

332. Qi, J.; Sun, X.; Tang, S.F.; Sun, Y.; Xu, C.; Li, X.; Li, X. Integrated study on the role of solvent, catalyst and reactant in the hydrodeoxygenation of eugenol over nickel-based catalysts. Appl. Catal. A Gen. 2017, 535, 24-31. [CrossRef]

333. Ambursa, M.M.; Sudarsanam, P.; Voon, L.H.; Hamid, S.B.A.; Bhargava, S.K. Bimetallic Cu-Ni catalysts supported on MCM-41 and Ti-MCM-41 porous materials for hydrodeoxygenation of lignin model compound into transportation fuels. Fuel Process. Technol. 2017, 162, 87-97. [CrossRef]

334. Li, X.; Chen, G.; Liu, C.; Ma, W.; Yan, B.; Zhang, J. Hydrodeoxygenation of lignin-derived bio-oil using molecular sieves supported metal catalysts: A critical review. Renew. Sustain. Energy Rev. 2017, 71, 296-308. [CrossRef]

335. Regmi, Y.N.; Mann, J.K.; McBride, J.R.; Tao, J.; Barnes, C.E.; Labbé, N.; Chmely, S.C. Catalytic transfer hydrogenolysis of organosolv lignin using B-containing FeNi alloyed catalysts. Catal. Today 2016, 5-10. [CrossRef]

336. Shao, Y.; Xia, Q.; Dong, L.; Liu, X.; Han, X.; Parker, S.F.; Cheng, Y.; Daemen, L.L.; Ramirez-Cuesta, A.J.; Yang, S.; et al. Selective production of arenes via direct lignin upgrading over a niobium-based catalyst. Nat. Commun. 2017, 8, 1-9. [CrossRef] [PubMed]

337. Jongerius, A.L.; Gosselink, R.W.; Dijkstra, J.; Bitter, J.H.; Bruijnincx, P.C.A.; Weckhuysen, B.M. Carbon nanofiber supported transition-metal carbide catalysts for the hydrodeoxygenation of guaiacol. Chem CatChem 2013, 5, 2964-2972. [CrossRef]

338. De, S.; Saha, B.; Luque, R. Hydrodeoxygenation processes: Advances on catalytic transformations of biomass-derived platform chemicals into hydrocarbon fuels. Bioresour. Technol. 2015, 178, 108-118. [CrossRef] [PubMed]

339. Löfstedt, J.; Dahlstrand, C.; Orebom, A.; Meuzelaar, G.; Sawadjoon, S.; Galkin, M.V.; Agback, P.; Wimby, M.; Corresa, E.; Mathieu, Y.; et al. Green Diesel from Kraft Lignin in Three Steps. ChemSusChem 2016, 9, 1392-1396. [CrossRef] [PubMed]

340. Abd Hamid, S.B.; Ambursa, M.M.; Sudarsanam, P.; Voon, L.H.; Bhargava, S.K. Effect of Ti loading on structure-activity properties of $\mathrm{Cu}-\mathrm{Ni} / \mathrm{Ti}-\mathrm{MCM}-41$ catalysts in hydrodeoxygenation of guaiacol. Catal. Commun. 2017, 94, 18-22. [CrossRef]

341. Bui, V.N.; Toussaint, G.; Laurenti, D.; Mirodatos, C.; Geantet, C. Co-processing of pyrolisis bio oils and gas oil for new generation of bio-fuels: Hydrodeoxygenation of guaïacol and SRGO mixed feed. Catal. Today 2009, 143, 172-178. [CrossRef]

342. Shafaghat, H.; Rezaei, P.S.; Ashri Wan Daud, W.M. Effective parameters on selective catalytic hydrodeoxygenation of phenolic compounds of pyrolysis bio-oil to high-value hydrocarbons. RSC Adv. 2015, 5, 103999-104042. [CrossRef]

343. Mäki-Arvela, P.; Murzin, D. Hydrodeoxygenation of Lignin-Derived Phenols: From Fundamental Studies towards Industrial Applications. Catalysts 2017, 7. [CrossRef]

344. Oh, S.; Hwang, H.; Choi, H.S.; Choi, J.W. Investigation of chemical modifications of micro- and macromolecules in bio-oil during hydrodeoxygenation with $\mathrm{Pd} / \mathrm{C}$ catalyst in supercritical ethanol. Chemosphere 2014, 117, 806-814. [CrossRef] [PubMed]

345. Oregui-Bengoechea, M.; Gandarias, I.; Miletić, N.; Simonsen, S.F.; Kronstad, A.; Arias, P.L.; Barth, T. Thermocatalytic conversion of lignin in an ethanol/formic acid medium with NiMo catalysts: Role of the metal and acid sites. Appl. Catal. B Environ. 2017, 217, 353-364. [CrossRef]

346. Korányi, T.I.; Hensen, E.J.M. Preparative Aspects of Supported $\mathrm{Ni}_{2} \mathrm{P}$ Catalysts for Reductive Upgrading of Technical Lignin to Aromatics. Catal. Lett. 2017, 147, 1722-1731. [CrossRef]

347. Demesa, A.G.; Laari, A.; Turunen, I.; Sillanpää, M. Alkaline Partial Wet Oxidation of Lignin for the Production of Carboxylic Acids. Chem. Eng. Technol. 2015, 38, 2270-2278. [CrossRef]

348. Demesa, A.G.; Laari, A.; Sillanp, M.; Koiranen, T. Valorization of lignin by partial wet oxidation using sustainable heteropoly acid catalysts. Molecules 2017, 22. [CrossRef] [PubMed]

349. Sales, F.G.; Abreu, C.A.M.; Pereira, J.A.F.R. Catalytic wet-air oxidation of lignin in a three-phase reactor with aromatic aldehyde production. Braz. J. Chem. Eng. 2004, 21, 211-218. [CrossRef] 
350. Araújo, J.D.P.; Grande, C.A.; Rodrigues, A.E. Vanillin production from lignin oxidation in a batch reactor. Chem. Eng. Res. Des. 2010, 88, 1024-1032. [CrossRef]

351. Ansaloni, S.; Russo, N.; Pirone, R. Wet Air Oxidation of Industrial Lignin Case Study: Influence of the Dissolution Pretreatment and Perovskite-type Oxides. Waste Biomass Valorization 2017, 1-15. [CrossRef]

352. Arandia, A.; Remiro, A.; Valle, B.; Bilbao, J.; Gayubo, A.G. Operating strategies for the oxidative steam reforming (OSR) of raw bio-oil in a continuous two-step system. Chem. Eng. Trans. 2017, 57, 217-222. [CrossRef]

353. Remiro, A.; Arandia, A.; Bilbao, J.; Gayubo, A.G. Comparison of Ni Based and Rh Based Catalyst Performance in the Oxidative Steam Reforming of Raw Bio-Oil. Energy Fuels 2017, 31, 7147-7156. [CrossRef]

354. Remiro, A.; Arandia, A.; Oar-Arteta, L.; Bilbao, J.; Gayubo, A.G. Stability of a Rh/CeO $-\mathrm{ZrO}_{2}$ Catalyst in the Oxidative Steam Reforming of Raw Bio-oil. Energy Fuels 2018, 32, 3588-3598. [CrossRef]

355. Ambrose, K.; Hurisso, B.B.; Singer, R.D. Recyclable ionic liquid tagged Co(salen) catalysts for the oxidation of lignin model compounds. Can. J. Chem. 2013, 91, 1258-1261. [CrossRef]

356. Aarabi, A.; Mizani, M.; Honarvar, M. The use of sugar beet pulp lignin for the production of vanillin. Int. J. Biol. Macromol. 2017, 94, 345-354. [CrossRef] [PubMed]

357. Ksenofontova, M.M.; Mitrofanova, A.N.; Pryakhin, A.N.; Lunin, V.V. Ozone reactions with lignins at various pH values. Russ. J. Phys. Chem. A 2005, 79, 1037-1041.

358. Khudoshin, A.G.; Mitrofanova, A.N.; Lunin, V.V. Lignin transformations and reactivity upon ozonation in aqueous media. Russ. J. Phys. Chem. A 2012, 86, 360-365. [CrossRef]

359. Mitrofanova, A.N.; Khudoshin, A.G.; Lunin, V.V. Mechanism of the catalytic ozonization of lignin in the presence of Mn(II) ions. Russ. J. Phys. Chem. A 2013, 87, 1124-1128. [CrossRef]

360. Alves, V.; Capanema, E.; Chen, C.L.; Gratzl, J. Comparative studies on oxidation of lignin model compounds with hydrogen peroxide using Mn(IV)-Me3TACN and Mn(IV)-Me4DTNE as catalyst. J. Mol. Catal. A Chem. 2003, 206, 37-51. [CrossRef]

361. Schutyser, W.; Van Den Bosch, S.; Dijkmans, J.; Turner, S.; Meledina, M.; Van Tendeloo, G.; Debecker, D.P.; Sels, B.F. Selective nickel-catalyzed conversion of model and lignin-derived phenolic compounds to cyclohexanone-based polymer building blocks. ChemSusChem 2015, 8, 1805-1818. [CrossRef] [PubMed]

362. Jennings, J.A.; Parkin, S.; Munson, E.; Delaney, S.P.; Calahan, J.L.; Isaacs, M.; Hong, K.; Crocker, M. Regioselective Baeyer-Villiger oxidation of lignin model compounds with tin beta zeolite catalyst and hydrogen peroxide. RSC Adv. 2017, 7, 25987-25997. [CrossRef]

363. Ma, R.; Xu, Y.; Zhang, X. Catalytic oxidation of biorefinery lignin to value-added chemicals to support sustainable biofuel production. ChemSusChem 2015, 8, 24-51. [CrossRef] [PubMed]

364. Das, L.; Kolar, P.; Sharma-Shivappa, R.; Classen, J.J.; Osborne, J.A. Catalytic Valorization of Lignin Using Niobium Oxide. Waste Biomass Valorization 2017, 8, 2673-2680. [CrossRef]

365. Crestini, C.; Crucianelli, M.; Orlandi, M.; Saladino, R. Oxidative strategies in lignin chemistry: A new environmental friendly approach for the functionalisation of lignin and lignocellulosic fibers. Catal. Today 2010, 156, 8-22. [CrossRef]

366. Dawange, M.; Galkin, M.V.; Samec, J.S.M. Selective aerobic benzylic alcohol oxidation of lignin model compounds: Route to aryl ketones. ChemCatChem 2015, 7, 401-404. [CrossRef]

367. Kärkäs, M.D.; Bosque, I.; Matsuura, B.S.; Stephenson, C.R.J. Photocatalytic Oxidation of Lignin Model Systems by Merging Visible-Light Photoredox and Palladium Catalysis. Org. Lett. 2016, 18, 5166-5169. [CrossRef] [PubMed]

368. Constant, S.; Robitzer, M.; Quignard, F.; Di Renzo, F. Vanillin oligomerization as a model of side reactions in lignin fragmentation. Catal. Today 2012, 189, 123-128. [CrossRef]

369. Ouyang, X.; Ruan, T.; Qiu, X. Effect of solvent on hydrothermal oxidation depolymerization of lignin for the production of monophenolic compounds. Fuel Process. Technol. 2016, 144, 181-185. [CrossRef]

370. Zhou, X.F. Catalytic Oxidation and Conversion of Kraft Lignin into Phenolic Products Using Zeolite-Encapsulated $\mathrm{Cu}(\mathrm{II})$ [H4]salen and [H2]salen Complexes. Environ. Prog. Sustain. Energy 2015, 34, 1120-1128. [CrossRef]

371. Zhou, X.F.; Lu, X.J. Co(salen) supported on graphene oxide for oxidation of lignin. J. Appl. Polym. Sci. 2016, 133, 1-9. [CrossRef] 
372. Springer, S.D.; He, J.; Chui, M.; Little, R.D.; Foston, M.; Butler, A. Peroxidative Oxidation of Lignin and a Lignin Model Compound by a Manganese SALEN Derivative. ACS Sustain. Chem. Eng. 2016, 4, 3212-3219. [CrossRef]

373. Hanson, S.K.; Baker, R.T.; Gordon, J.C.; Scott, B.L.; Thorn, D.L. Aerobic oxidation of lignin models using a base metal vanadium catalyst. Inorg. Chem. 2010, 49, 5611-5618. [CrossRef] [PubMed]

374. Sedai, B.; Díaz-Urrutia, C.; Baker, R.T.; Wu, R.; Silks, L.A.P.; Hanson, S.K. Aerobic oxidation of $\beta-1$ lignin model compounds with copper and oxovanadium catalysts. ACS Catal. 2013, 3, 3111-3122. [CrossRef]

375. Jiang, Y.Y.; Yan, L.; Yu, H.Z.; Zhang, Q.; Fu, Y. Mechanism of Vanadium-Catalyzed Selective C-O and C-C Cleavage of Lignin Model Compound. ACS Catal. 2016, 6, 4399-4410. [CrossRef]

376. Rahimi, A.; Azarpira, A.; Kim, H.; Ralph, J.; Stahl, S.S. Chemoselective metal-free aerobic alcohol oxidation in lignin. J. Am. Chem. Soc. 2013, 135, 6415-6418. [CrossRef] [PubMed]

377. Patil, N.D.; Yan, N. Investigate cleavage of $\beta-\mathrm{O}-4$ linkage in lignin model compounds by aerobic oxidation of $\mathrm{C} \alpha$ and $\mathrm{C} \gamma$ hydroxyl groups. Tetrahedron Lett. 2016, 57, 3024-3028. [CrossRef]

378. Fang, Z.; Meier, M.S. Toward the oxidative deconstruction of lignin: Oxidation of $\beta-1$ and $\beta-5$ linkages. Org. Biomol. Chem. 2018, 16, 2330-2341. [CrossRef] [PubMed]

379. Meister, J.J. Modification of lignin. J. Macromol. Sci. Part C 2002, 42, 235-289. [CrossRef]

380. Cavani, F.; Maselli, L.; Passeri, S.; Lercher, J.A. Catalytic methylation of phenol on MgO-Surface chemistry and mechanism. J. Catal. 2010, 269, 340-350. [CrossRef]

381. Lai, C.; Tu, M.; Xia, C.; Shi, Z.; Sun, S.; Yong, Q.; Yu, S. Lignin Alkylation Enhances Enzymatic Hydrolysis of Lignocellulosic Biomass. Energy Fuels 2017, 31, 12317-12326. [CrossRef]

382. Nie, G.; Zhang, X.; Han, P.; Xie, J.; Pan, L.; Wang, L.; Zou, J.J. Lignin-derived multi-cyclic high density biofuel by alkylation and hydrogenated intramolecular cyclization. Chem. Eng. Sci. 2017, 158, 64-69. [CrossRef]

383. Pandey, K.K.; Vuorinen, T. Study of kinetics of reaction of lignin model compounds with propylene oxide. Holzforschung 2008, 62, 169-175. [CrossRef]

384. Cachet, N.; Camy, S.; Benjelloun-Mlayah, B.; Condoret, J.S.; Delmas, M. Esterification of organosolv lignin under supercritical conditions. Ind. Crops Prod. 2014, 58, 287-297. [CrossRef]

385. Dehne, L.; Vila Babarro, C.; Saake, B.; Schwarz, K.U. Influence of lignin source and esterification on properties of lignin-polyethylene blends. Ind. Crops Prod. 2016, 86, 320-328. [CrossRef]

386. Zhao, X.; Zhang, Y.; Wei, L.; Hu, H.; Huang, Z.; Yang, M.; Huang, A.; Wu, J.; Feng, Z. Esterification mechanism of lignin with different catalysts based on lignin model compounds by mechanical activation-assisted solid-phase synthesis. RSC Adv. 2017, 7, 52382-52390. [CrossRef]

387. Yang, S.; Wen, J.-L.; Yuan, T.-Q.; Sun, R.-C. Characterization and phenolation of biorefinery technical lignins for lignin-phenol-formaldehyde resin adhesive synthesis. RSC Adv. 2014, 4, 57996-58004. [CrossRef]

388. Podschun, J.; Stücker, A.; Saake, B.; Lehnen, R. Structure-function relationships in the phenolation of lignins from different sources. ACS Sustain. Chem. Eng. 2015, 3, 2526-2532. [CrossRef]

389. Jiang, X.; Liu, J.; Du, X.; Hu, Z.; Chang, H.; Jameel, H. Phenolation to Improve Lignin Reactivity toward Thermosets Application. ACS Sustain. Chem. Eng. 2018. [CrossRef]

390. Chauhan, M.; Gupta, M.; Singh, B.; Singh, A.K.; Gupta, V.K. Effect of functionalized lignin on the properties of lignin-isocyanate prepolymer blends and composites. Eur. Polym. J. 2014, 52, 32-43. [CrossRef]

391. Gómez-Fernández, S.; Ugarte, L.; Calvo-Correas, T.; Peña-Rodríguez, C.; Corcuera, M.A.; Eceiza, A. Properties of flexible polyurethane foams containing isocyanate functionalized kraft lignin. Ind. Crops Prod. 2017, 100, 51-64. [CrossRef]

392. Beckham, G.T.; Johnson, C.W.; Karp, E.M.; Salvachúa, D.; Vardon, D.R. Opportunities and challenges in biological lignin valorization. Curr. Opin. Biotechnol. 2016, 42, 40-53. [CrossRef] [PubMed]

393. Rodríguez-Couto, S. Industrial and environmental applications of white-rot fungi. Mycosphere 2017, 8, 456-466. [CrossRef]

394. Brown, M.E.; Chang, M.C.Y. Exploring bacterial lignin degradation. Curr. Opin. Chem. Biol. 2014, $19,1-7$. [CrossRef] [PubMed]

395. Baker, P.W.; Charlton, A.; Hale, M.D.C. Fungal pre-treatment of forestry biomass with a focus on biorefining: A comparison of biomass degradation and enzyme activities by wood rot fungi across three tree species. Biomass Bioenergy 2017, 107, 20-28. [CrossRef] 
396. Wang, W.; Zhang, C.; Sun, X.; Su, S.; Li, Q.; Linhardt, R.J. Efficient, environmentally-friendly and specific valorization of lignin: promising role of non-radical lignolytic enzymes. World J. Microbiol. Biotechnol. 2017, 33, 1-14. [CrossRef] [PubMed]

397. Bugg, T.D.H.; Ahmad, M.; Hardiman, E.M.; Singh, R. The emerging role for bacteria in lignin degradation and bio-product formation. Curr. Opin. Biotechnol. 2011, 22, 394-400. [CrossRef] [PubMed]

398. Dashtban, M.; Schraft, H.; Syed, T.A.; Qin, W. Fungal biodegradation and enzymatic modification of lignin. Int. J. Biochem. Mol. Biol. 2010, 1, 36-50. [PubMed]

399. Hofricher, M. Review: Lignin conversiton by manganese peroxidase (MnP). Enzym. Microb. Technol. $2002,30$. [CrossRef]

400. Picart, P.; Liu, H.; Grande, P.M.; Anders, N.; Zhu, L.; Klankermayer, J.; Leitner, W.; Domínguez de María, P.; Schwaneberg, U.; Schallmey, A. Multi-step biocatalytic depolymerization of lignin. Appl. Microbiol. Biotechnol. 2017, 101, 6277-6287. [CrossRef] [PubMed]

401. Xie, S.; Sun, Q.; Pu, Y.; Lin, F.; Sun, S.; Wang, X.; Ragauskas, A.J.; Yuan, J.S. Advanced Chemical Design for Efficient Lignin Bioconversion. ACS Sustain. Chem. Eng. 2017, 5, 2215-2223. [CrossRef]

402. Rashid, G.M.M.; Taylor, C.R.; Liu, Y.; Zhang, X.; Rea, D.; Fülöp, V.; Bugg, T.D.H. Identification of Manganese Superoxide Dismutase from Sphingobacterium sp. T2 as a Novel Bacterial Enzyme for Lignin Oxidation. ACS Chem. Biol. 2015, 10, 2286-2294. [CrossRef] [PubMed]

403. Picart, P.; De María, P.D.; Schallmey, A. From gene to biorefinery: Microbial $\beta$-etherases as promising biocatalysts for lignin valorization. Front. Microbiol. 2015, 6, 1-8. [CrossRef] [PubMed]

404. Helmich, K.E.; Pereira, J.H.; Gall, D.L.; Heins, R.A.; McAndrew, R.P.; Bingman, C.; Deng, K.; Holland, K.C.; Noguera, D.R.; Simmons, B.A.; et al. Structural basis of stereospecificity in the bacterial enzymatic cleavage of $\beta$-aryl ether bonds in lignin. J. Biol. Chem. 2016, 291, 5234-5246. [CrossRef] [PubMed]

405. Picart, P.; Sevenich, M.; Domínguez de María, P.; Schallmey, A. Exploring glutathione lyases as biocatalysts: Paving the way for enzymatic lignin depolymerization and future stereoselective applications. Green Chem. 2015, 17, 4931-4940. [CrossRef]

406. Bandounas, L.; Wierckx, N.; de Winde, J.; Ruijssenaars, H. Isolation and characterization of novel bacterial strains exhibiting ligninolytic potential. BMC Biotechnol. 2011, 11, 94. [CrossRef] [PubMed]

407. Gassara, F.; Brar, S.K.; Tyagi, R.D.; John, R.P.; Verma, M.; Valero, J.R. Parameter optimization for production of ligninolytic enzymes using agro-industrial wastes by response surface method. Biotechnol. Bioprocess Eng. 2011, 16, 343-351. [CrossRef]

408. Schalchli, H.; Hormazábal, E.; Rubilar, O.; Briceño, G.; Mutis, A.; Zocolo, G.J.; Diez, M.C. Production of ligninolytic enzymes and some diffusible antifungal compounds by white-rot fungi using potato solid wastes as the sole nutrient source. J. Appl. Microbiol. 2017, 123, 886-895. [CrossRef] [PubMed]

409. Paramjeet, S.; Manasa, P.; Korrapati, N. Biofuels: Production of fungal-mediated ligninolytic enzymes and the modes of bioprocesses utilizing agro-based residues. Biocatal. Agric. Biotechnol. 2018, 14, 57-71. [CrossRef]

410. Wells, T.; Ragauskas, A.J. Biotechnological opportunities with the $\beta$-ketoadipate pathway. Trends Biotechnol. 2012, 30, 627-637. [CrossRef] [PubMed]

411. Ravi, K.; García-Hidalgo, J.; Nöbel, M.; Gorwa-Grauslund, M.F.; Lidén, G. Biological conversion of aromatic monolignol compounds by a Pseudomonas isolate from sediments of the Baltic Sea. AMB Express 2018, 8. [CrossRef] [PubMed]

412. Linger, J.G.; Vardon, D.R.; Guarnieri, M.T.; Karp, E.M.; Hunsinger, G.B.; Franden, M.A.; Johnson, C.W.; Chupka, G.; Strathmann, T.J.; Pienkos, P.T.; et al. Lignin valorization through integrated biological funneling and chemical catalysis. Proc. Natl. Acad. Sci. USA 2014, 111, 12013-12018. [CrossRef] [PubMed]

413. Varman, A.M.; He, L.; Follenfant, R.; Wu, W.; Wemmer, S.; Wrobel, S.A.; Tang, Y.J.; Singh, S. Decoding how a soil bacterium extracts building blocks and metabolic energy from ligninolysis provides road map for lignin valorization. Proc. Natl. Acad. Sci. USA 2016, 113, E5802-E5811. [CrossRef] [PubMed]

414. Kim, C.H.S.; Choi, S.P.J. Catabolic Pathway of Lignin Derived-Aromatic Compounds by Whole Cell of Phanerochaete chrysosporium (ATCC 20696) With Reducing Agent. J. Korean Wood Sci. Technol. 2017, 45, 168-181.

415. Salvachúa, D.; Karp, E.M.; Nimlos, C.T.; Vardon, D.R.; Beckham, G.T. Towards lignin consolidated bioprocessing: Simultaneous lignin depolymerization and product generation by bacteria. Green Chem. 2015, 17, 4951-4967. [CrossRef] 
416. Tian, J.H.; Pourcher, A.M.; Peu, P. Isolation of bacterial strains able to metabolize lignin and lignin-related compounds. Lett. Appl. Microbiol. 2016, 63, 30-37. [CrossRef] [PubMed]

417. Sainsbury, P.D.; Mineyeva, Y.; Mycroft, Z.; Bugg, T.D.H. Chemical intervention in bacterial lignin degradation pathways: Development of selective inhibitors for intradiol and extradiol catechol dioxygenases. Bioorg. Chem. 2015, 60, 102-109. [CrossRef] [PubMed]

418. Vardon, D.R.; Franden, M.A.; Johnson, C.W.; Karp, E.M.; Guarnieri, M.T.; Linger, J.G.; Salm, M.J.; Strathmann, T.J.; Beckham, G.T. Adipic acid production from lignin. Energy Environ. Sci. 2015, 8, 617-628. [CrossRef]

419. Johnson, C.W.; Beckham, G.T. Aromatic catabolic pathway selection for optimal production of pyruvate and lactate from lignin. Metab. Eng. 2015, 28, 240-247. [CrossRef] [PubMed]

420. Johnson, C.W.; Abraham, P.E.; Linger, J.G.; Khanna, P.; Hettich, R.L.; Beckham, G.T. Eliminating a global regulator of carbon catabolite repression enhances the conversion of aromatic lignin monomers to muconate in Pseudomonas putida KT2440. Metab. Eng. Commun. 2017, 5, 19-25. [CrossRef] [PubMed]

421. Wu, W.; Dutta, T.; Varman, A.M.; Eudes, A.; Manalansan, B.; Loqué, D.; Singh, S. Lignin Valorization: Two Hybrid Biochemical Routes for the Conversion of Polymeric Lignin into Value-added Chemicals. Sci. Rep. 2017, 7, 1-13. [CrossRef] [PubMed]

422. Ohta, Y.; Hasegawa, R.; Kurosawa, K.; Maeda, A.H.; Koizumi, T.; Nishimura, H.; Okada, H.; Qu, C.; Saito, K.; Watanabe, T.; et al. Enzymatic Specific Production and Chemical Functionalization of Phenylpropanone Platform Monomers from Lignin. ChemSusChem 2017, 10, 425-433. [CrossRef] [PubMed]

423. Van de Pas, D.; Hickson, A.; Donaldson, L.; Lloyd-Jones, G.; Tamminen, T.; Fernyhough, A.; Mattinen, M.L. Characterization of fractionated lignins polymerized by fungal laccases. BioResources 2011, 6, 1105-1121.

424. Moya, R.; Saastamoinen, P.; Hernández, M.; Suurnäkki, A.; Arias, E.; Mattinen, M.L. Reactivity of bacterial and fungal laccases with lignin under alkaline conditions. Bioresour. Technol. 2011, 102, 10006-10012. [CrossRef] [PubMed]

425. Rodríguez-Escribano, D.; de Salas, F.; Pardo, I.; Camarero, S. High-throughput screening assay for laccase engineering toward lignosulfonate valorization. Int. J. Mol. Sci. 2017, 18. [CrossRef] [PubMed]

426. Cannatelli, M.D.; Ragauskas, A.J. Laccase-mediated synthesis of lignin-core hyperbranched copolymers. Appl. Microbiol. Biotechnol. 2017, 101, 6343-6353. [CrossRef] [PubMed]

427. Stewart, D. Lignin as a base material for materials applications: Chemistry, application and economics. Ind. Crops Prod. 2008, 27, 202-207. [CrossRef]

428. Feldman, D. Lignin and its polyblends-A review. In Chemical Modification, Properties, and Usage of Lignin; Hu, T.Q., Ed.; Springer: New York, NY, USA, 2002; pp. 81-100.

429. Doherty, W.O.S.; Mousavioun, P.; Fellows, C.M. Value-adding to cellulosic ethanol: Lignin polymers. Ind. Crops Prod. 2011, 33, 259-276. [CrossRef]

430. Liu, R.; Peng, Y.; Cao, J.; Chen, Y. Comparison on properties of lignocellulosic flour/polymer composites by using wood, cellulose, and lignin flours as fillers. Compos. Sci. Technol. 2014, 103, 1-7. [CrossRef]

431. Naghmouchi, I.; Mutjé, P.; Boufi, S. Olive stones flour as reinforcement in polypropylene composites: A step forward in the valorization of the solid waste from the olive oil industry. Ind. Crops Prod. 2014, 72, 183-191. [CrossRef]

432. Angelini, S.; Cerruti, P.; Immirzi, B.; Scarinzi, G.; Malinconico, M. Acid-insoluble lignin and holocellulose from a lignocellulosic biowaste: Bio-fillers in poly(3-hydroxybutyrate). Eur. Polym. J. 2016, 76, 63-76. [CrossRef]

433. Košíková, B.; Gregorová, A. Sulfur-free lignin as reinforcing component of styrene-butadiene rubber. J. Appl. Polym. Sci. 2005, 97, 924-929. [CrossRef]

434. Bahl, K.; Miyoshi, T.; Jana, S.C. Hybrid fillers of lignin and carbon black for lowering of viscoelastic loss in rubber compounds. Polymer 2014, 55, 3825-3835. [CrossRef]

435. Klanwan, Y.; Kunanopparat, T.; Menut, P.; Siriwattanayotin, S. Valorization of industrial by-products through bioplastic production: Defatted rice bran and kraft lignin utilization. J. Polym. Eng. 2016, 36, 529-536. [CrossRef]

436. Huang, J.; Zhang, L.; Chen, F. Effects of lignin as a filler on properties of soy protein plastics. I. Lignosulfonate. J. Appl. Polym. Sci. 2003, 88, 3284-3290. [CrossRef] 
437. Dörrstein, J.; Scholz, R.; Schwarz, D.; Schieder, D.; Sieber, V.; Walther, F.; Zollfrank, C. Effects of high-lignin-loading on thermal, mechanical, and morphological properties of bioplastic composites. Compos. Struct. 2018, 189, 349-356. [CrossRef]

438. Zhang, J.; Fleury, E.; Chen, Y.; Brook, M.A. Flame retardant lignin-based silicone composites. RSC Adv. 2015, 5, 103907-103914. [CrossRef]

439. Barana, D.; Ali, S.D.; Salanti, A.; Orlandi, M.; Castellani, L.; Hanel, T.; Zoia, L. Influence of Lignin Features on Thermal Stability and Mechanical Properties of Natural Rubber Compounds. ACS Sustain. Chem. Eng. 2016, 4, 5258-5267. [CrossRef]

440. Kai, D.; Tan, M.J.; Chee, P.L.; Chua, Y.K.; Yap, Y.L.; Loh, X.J. Towards lignin-based functional materials in a sustainable world. Green Chem. 2016, 18, 1175-1200. [CrossRef]

441. Tian, D.; Hu, J.; Bao, J.; Chandra, R.P.; Saddler, J.N.; Lu, C. Lignin valorization: Lignin nanoparticles as high-value bio-additive for multifunctional nanocomposites. Biotechnol. Biofuels 2017, 10, 1-11. [CrossRef] [PubMed]

442. Sen, S.; Patil, S.; Argyropoulos, D.S. Thermal properties of lignin in copolymers, blends, and composites: A review. Green Chem. 2015, 17, 4862-4887. [CrossRef]

443. Naseem, A.; Tabasum, S.; Zia, K.M.; Zuber, M.; Ali, M.; Noreen, A. Lignin-derivatives based polymers, blends and composites: A review. Int. J. Biol. Macromol. 2016, 93, 296-313. [CrossRef] [PubMed]

444. Calvo-Flores, F.G.; Dobado, J.A. Lignin as renewable raw material. ChemSusChem 2010, 3, 1227-1235. [CrossRef] [PubMed]

445. Duval, A.; Lawoko, M. A review on lignin-based polymeric, micro- and nano-structured materials. React. Funct. Polym. 2014, 85, 78-96. [CrossRef]

446. Thakur, V.K.; Thakur, M.K.; Raghavan, P.; Kessler, M.R. Progress in green polymer composites from lignin for multifunctional applications: A review. ACS Sustain. Chem. Eng. 2014, 2, 1072-1092. [CrossRef]

447. Kun, D.; Pukánszky, B. Polymer/lignin blends: Interactions, properties, applications. Eur. Polym. J. 2017, 93, 618-641. [CrossRef]

448. Wang, Y.-Y.; Cai, C.M.; Ragauskas, A.J. Recent advances in lignin-based polyurethanes. TAPPI J. 2017, 16, 203-207.

449. Cateto, C.A.; Barreiro, M.F.; Rodrigues, A.E.; Brochier-Salon, M.C.; Thielemans, W.; Belgacem, M.N. Lignins as Macromonomers for Polyurethane Synthesis: A Comparative Study on Hydroxyl Group Determination. J. Appl. Polym. Sci. 2008, 109, 3008-3017. [CrossRef]

450. Laurichesse, S.; Huillet, C.; Avérous, L. Original polyols based on organosolv lignin and fatty acids: New bio-based building blocks for segmented polyurethane synthesis. Green Chem. 2014, 16, 3958-3970. [CrossRef]

451. De Oliveira, F.; Ramires, E.C.; Frollini, E.; Belgacem, M.N. Lignopolyurethanic materials based on oxypropylated sodium lignosulfonate and castor oil blends. Ind. Crops Prod. 2015, 72, 77-86. [CrossRef]

452. Kai, D.; Zhang, K.; Jiang, L.; Wong, H.Z.; Li, Z.; Zhang, Z.; Loh, X.J. Sustainable and Antioxidant Lignin-Polyester Copolymers and Nanofibers for Potential Healthcare Applications. ACS Sustain. Chem. Eng. 2017, 5, 6016-6025. [CrossRef]

453. Siahmed, F.; Lounis, A.; Faghi, L. Elaboration, characterization, and degradation of composite material: Lignocellulosic/unsaturated polyester. J. Compos. Mater. 2013, 47, 2965-2972. [CrossRef]

454. Sivasankarapillai, G.; McDonald, A.G.; Li, H. Lignin valorization by forming toughened lignin-co-polymers: Development of hyperbranched prepolymers for cross-linking. Biomass Bioenergy 2012, 47, 99-108. [CrossRef]

455. Li, H.; Sivasankarapillai, G.; McDonald, A.G. Lignin valorization by forming thermally stimulated shape memory copolymeric elastomers-Partially crystalline hyperbranched polymer as crosslinks. J. Appl. Polym. Sci. 2014, 131, 1-10. [CrossRef]

456. Li, H.; Sivasankarapillai, G.; McDonald, A.G. Lignin valorization by forming toughened thermally stimulated shape memory copolymeric elastomers: Evaluation of different fractionated industrial lignins. J. Appl. Polym. Sci. 2015, 132, 1-12. [CrossRef]

457. Mousavioun, P.; George, G.A.; Doherty, W.O.S. Environmental degradation of lignin/poly(hydroxybutyrate) blends. Polym. Degrad. Stab. 2012, 97, 1114-1122. [CrossRef]

458. Chung, Y.L.; Olsson, J.V.; Li, R.J.; Frank, C.W.; Waymouth, R.M.; Billington, S.L.; Sattely, E.S. A renewable lignin-lactide copolymer and application in biobased composites. ACS Sustain. Chem. Eng. 2013, 1, 1231-1238. [CrossRef] 
459. Hambardzumyan, A.; Foulon, L.; Bercu, N.B.; Pernes, M.; Maigret, J.E.; Molinari, M.; Chabbert, B.; Aguié-Béghin, V. Organosolv lignin as natural grafting additive to improve the water resistance of films using cellulose nanocrystals. Chem. Eng. J. 2015, 264, 780-788. [CrossRef]

460. Chatterjee, S.; Saito, T. Lignin-Derived Advanced Carbon Materials. ChemSusChem 2015, 8, 3941-3958. [CrossRef] [PubMed]

461. Suhas; Carrott, P.J.M.; Ribeiro Carrott, M.M.L. Lignin-From natural adsorbent to activated carbon: A review. Bioresour. Technol. 2007, 98, 2301-2312. [CrossRef] [PubMed]

462. Sangchoom, W.; Mokaya, R. Valorization of Lignin Waste: Carbons from Hydrothermal Carbonization of Renewable Lignin as Superior Sorbents for $\mathrm{CO}_{2}$ and Hydrogen Storage. ACS Sustain. Chem. Eng. 2015, 3, 1658-1667. [CrossRef]

463. Shen, Q.; Zhang, T.; Zhang, W.-X.; Chen, S.; Mezgebe, M. Lignin-Based Activated Carbon Fibers and Controllable Pore Size and Properties. J. Appl. Polym. Sci. 2011, 121, 989-994. [CrossRef]

464. Song, M.; Zhang, W.; Chen, Y.; Luo, J.; Crittenden, J.C. The preparation and performance of lignin-based activated carbon fiber adsorbents for treating gaseous streams. Front. Chem. Sci. Eng. 2017, 11, 328-337. [CrossRef]

465. Shi, X.; Wang, X.; Tang, B.; Dai, Z.; Chen, K.; Zhou, J. Impact of lignin extraction methods on microstructure and mechanical properties of lignin-based carbon fibers. J. Appl. Polym. Sci. 2018, 135, 1-7. [CrossRef]

466. Lin, J.; Koda, K.; Kubo, S.; Yamada, T.; Enoki, M.; Uraki, Y. Improvement of mechanical properties of softwood lignin-based carbon fibers. J. Wood Chem. Technol. 2014, 34, 111-121. [CrossRef]

467. Kleinhans, H.; Salmén, L. Development of lignin carbon fibers: Evaluation of the carbonization process. J. Appl. Polym. Sci. 2016, 133, 1-7. [CrossRef]

468. Dai, Z.; Shi, X.; Liu, H.; Li, H.; Han, Y.; Zhou, J. High-strength lignin-based carbon fibers via a low-energy method. RSC Adv. 2018, 8, 1218-1224. [CrossRef]

469. Myllytie, P.; Misra, M.; Mohanty, A.K. Carbonized Lignin as Sustainable Filler in Biobased Poly(trimethylene terephthalate) Polymer for Injection Molding Applications. ACS Sustain. Chem. Eng. 2016, 4, 102-110. [CrossRef]

470. Hu, S.; Jiang, F.; Hsieh, Y. Lo 1D lignin-based solid acid catalysts for cellulose hydrolysis to glucose and nanocellulose. ACS Sustain. Chem. Eng. 2015, 3, 2566-2574. [CrossRef]

471. Chieffi, G.; Fechler, N.; Esposito, D. Valorization of lignin waste from hydrothermal treatment of biomass: Towards porous carbonaceous composites for continuous hydrogenation. RSC Adv. 2015, 5, 63691-63696. [CrossRef]

472. Gong, W.; Ran, Z.; Ye, F.; Zhao, G. Lignin from bamboo shoot shells as an activator and novel immobilizing support for $\alpha$-amylase. Food Chem. 2017, 228, 455-462. [CrossRef] [PubMed]

473. Lam, E.; Luong, J.H.T. Carbon materials as catalyst supports and catalysts in the transformation of biomass to fuels and chemicals. ACS Catal. 2014, 4, 3393-3410. [CrossRef]

474. Ochoa, A.; Aramburu, B.; Ibáñez, M.; Valle, B.; Bilbao, J.; Gayubo, A.G.; Castaño, P. Compositional Insights and Valorization Pathways for Carbonaceous Material Deposited during Bio-Oil Thermal Treatment. ChemSusChem 2014, 7, 2597-2608. [CrossRef] [PubMed]

475. Cerrutti, B.M.; Moraes, M.L.; Pulcinelli, S.H.; Santilli, C.V. Lignin as immobilization matrix for HIV p17 peptide used in immunosensing. Biosens. Bioelectron. 2015, 71, 420-426. [CrossRef] [PubMed]

476. Ago, M.; Borghei, M.; Haataja, J.S.; Rojas, O.J. Mesoporous carbon soft-templated from lignin nanofiber networks: Microphase separation boosts supercapacitance in conductive electrodes. RSC Adv. 2016, 6, 85802-85810. [CrossRef]

477. Tran, C.D.; Ho, H.C.; Keum, J.K.; Chen, J.; Gallego, N.C.; Naskar, A.K. Sustainable Energy-Storage Materials from Lignin-Graphene Nanocomposite-Derived Porous Carbon Film. Energy Technol. 2017, 5, 1927-1935. [CrossRef]

478. Nowak, A.P.; Hagberg, J.; Leijonmarck, S.; Schweinebarth, H.; Baker, D.; Uhlin, A.; Tomani, P.; Lindbergh, G. Lignin-based carbon fibers for renewable and multifunctional lithium-ion battery electrodes. Holzforschung 2018, 72, 81-90. [CrossRef]

479. Luo, H.; Abu-Omar, M.M. Chemicals from Lignin. In Encyclopedia of Sustainable Technologies; Elsevier: Amsterdam, The Netherlands, 2017; pp. 573-585. ISBN 9780128046777. 
480. Trebostad, M. Renewable Chemicals from Lignin-A Conceptual Evaluation of Thermochemical Processes for Production of Valuable Chemicals from Lignin. Master's Thesis, Norwegian University of Life Sciences, Ås, Norway, 2016.

481. Strassberger, Z.; Tanase, S.; Rothenberg, G. The pros and cons of lignin valorisation in an integrated biorefinery. RSC Adv. 2014, 4, 25310-25318. [CrossRef] 